\title{
The Road to Twining: \\ Reassessing the Disincorporation of the Bill of Rights
}

\author{
BRYANH. WILDENTHAL*
}

This article-a sequel to Professor Wildenthal's article The Lost Compromise in the previous issue of the Ohio State Law Journal-analyzes the early understanding in the Supreme Court, from 1880 to 1908, regarding incorporation of the Bill of Rights in the Fourteenth Amendment. Professor Wildenthal offers a fresh and comprehensive analysis of all the relevant cases, with special attention to the briefs and arguments presented to the Court, a resource previously underused by scholars. The article demonstrates that the incorporationist reading of the 1873 Slaughter-House Cases (discussed in Professor Wildenthal's previous article) reverberated in the first extensive pro-incorporation argument presented to the Court, by John Randolph Tucker in Spies v. Illinois (1887). That unconventional reading of Slaughter-House also played a role in the dissents by three Justices who embraced the incorporation theory in O'Neil v. Vermont (1892). Professor Wildenthal details the treatment of that theory up through the Court's historic decision in Twining v. New Jersey (1908), which embraced a theory of total disincorporation. He shows how this early case law has been profoundly misunderstood by earlier scholars, notably by Professor Stanley Morrison in a 1949 Stanford Law Review article (the companion to Professor Charles Fairman's famous analysis of the original understanding of the Fourteenth Amendment). In particular, Professor Wildenthal defends the first Justice John Marshall Harlan's historic and critical role in these cases. The article concludes

* Associate Professor of Law, Thomas Jefferson School of Law, San Diego, Califomia. A.B., 1986, J.D., 1989, Stanford University. I dedicate this article with love to my parents, Joyce Fay Lockhart Wildenthal and B. Hobson Wildenthal, Sr., for all of their immeasurable love and support over the years. I presented a talk on this article and its predecessor, see infra note 9, at Thomas Jefferson School of Law on September 29, 1999, and I thank the participants from all three San Diego law schools for their feedback. For their generosity in reading drafts and providing comments, I especially thank (while of course taking full blame myself for any errors or eccentricities herein): Dean Richard Aynes of University of Akron School of Law; Associate Dean Daniel Farber of University of Minnesota Law School; Professor John Hart Ely of University of Miami School of Law; Professor Ronald Krotoszynski of Washington and Lee University School of Law; Associate Dean Marybeth Herald and Professor Susan Tiefenbrun of Thomas Jefferson School of Law; Professor Emeritus Harold Hyman of Rice University History Department; and above all, Professor Michael Kent Curtis of Wake Forest University School of Law, whose encouragement was especially heartening. I also thank Thomas Jefferson School of Law and Dean Kenneth Vandevelde for a summer stipend to complete this project. Finally, I owe a very special thanks to Thomas Jefferson School of Law librarians Brent Bernau and Dorothy Hampton, and library assistant John Fernandez, for their tireless and cheerful help in locating and working with various nineteenth-century briefs, congressional records, and treatises. 
by surveying the Court's modern treatment of the incorporation theory, and by noting the recent revival of the Fourteenth Amendment Privileges and Immunities Clause in Saenz v. Roe (1999). Professor Wildenthal argues that the evidence analyzed in articles should place the incorporation theory on a stronger foundation as the Court faces a new century.

\section{TABLE OF CONTENTS}

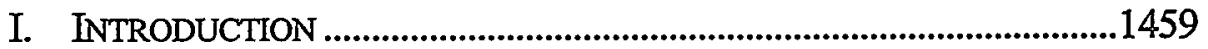

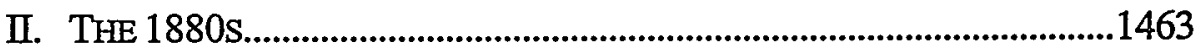

A. Justice Harlan's Arrival on the Scene.......................................1463

B. Hurtado and the Grand Jury Problem ........................................1469

C. Slaughter-House Revisited and Presser.......................................1480

D. John Randolph Tucker and the Spies Appeal ..............................1484

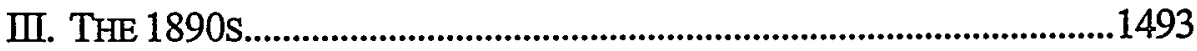

A. The Crossroads of O'Neil.......................................................1494

B. The Curious Exception of Chicago B\&Q ...................................1501

IV. THE DAWN OF A NEW CENTURY AND THE END OF AN AULD SANG: MAXWELL, PATTERSON, AND TWINING.

V. THE BEGINNINGS OF A NEW SONG:

1947, 1969, 1999, AND BEYOND 
The Fourteenth Amendment ... provides that "no State shall make or enforce any law which shall abridge the privileges or immunities of citizens of the United States...."

What are the privileges and immunities of "citizens of the United States"? Without attempting to enumerate them, it ought to be deemed safe to say that such privileges and immunities embrace at least those expressly recognized by the Constitution of the United States and placed beyond the power of Congress to take away or impair. ${ }^{1}$

\section{INTRODUCTION}

In 1908, in Twining $v$. New Jersey, ${ }^{2}$ a majority of the Justices of the Supreme Court, over the dissent of the first Justice John Marshall Harlan, conceded that their predecessors had given "much less effect to the Fourteenth Amendment than some of the public men active in framing it intended."3 "But," they said, "we need not now inquire into the merits of the original dispute.... The distinction between national and state citizenship and their respective privileges [previously] drawn has come to be firmly established." 4 The majority was referring to the scope of the Privileges and Immunities Clause of the Fourteenth Amendment. ${ }^{5}$ They conceded that the "view [that this clause incorporates the Bill of Rights] has been, at different times, expressed by justices of this court ... and was undoubtedly ... entertained by some of those who framed the Amendment." 6 They rejected the idea, however, concluding that it was "not profitable to examine the weighty arguments in its favor, for the question is no longer open in this court."?

The Twining Court was discussing the Great Debate over "incorporation," or whether and to what extent the Fourteenth Amendment applies to the states the guarantees of the federal Bill of Rights. ${ }^{8}$ In a recent article in this journal, this author began the task of "revisit[ing] th[at] most durable and ceaselessly

${ }^{1}$ Maxwell v. Dow, 176 U.S. 581, 606 (1900) (Harlan, J., dissenting).

2211 U.S. 78 (1908).

${ }^{3}$ Id. at 96.

${ }^{4} I d$.

5 'No State shall make or enforce any law which shall abridge the privileges or immunities of citizens of the United States ...."U.S. CONST. amend. XIV, § 1.

6 Twining, 211 U.S. at 98.

7 Id.

${ }^{8}$ U.S. CONST. amends. I-VIII, XIV. 
provocative controversy in American constitutional law."9 That article explored the early post-ratification understanding on incorporation during the period from 1868 to 1880 , looking to the opinions of the Supreme Court, the briefs and arguments by lawyers before the Court, and-most dramatically-key debates in Congress. It demonstrated that more than a century of conventional wisdom on the early understanding of the Fourteenth Amendment must be overturned. ${ }^{10}$

The Court's decision in the Slaughter-House Cases of $1873^{11}$ has conventionally been viewed as rejecting incorporation and gutting the Privileges and Immunities Clause. ${ }^{12}$ In fact, total incorporation via the Privileges and Immunities Clause may well have been embraced by all nine Justices in SlaughterHouse, including Justice Samuel F. Miller's majority opinion. ${ }^{13}$ This author's previous article, building upon the work of prior scholars, showed how this theory is supported by a careful reading of Justice Miller's opinion itself. It also explored more thoroughly than previous scholarship the implications of carefully reading all three Slaughter-House dissents, so as to better understand the overall dialectic of

${ }^{9}$ Bryan H. Wildenthal, The Lost Compromise: Reassessing the Early Understanding in Court and Congress on Incorporation of the Bill of Rights in the Fourteenth Amendment, 61 OHо ST. L.J. 1051, 1054 [hereinafter Wildenthal, Lost Compromise].

${ }^{10}$ See generally id.

1183 U.S. (16 Wall.) 36 (1873).

12 See, e.g., GERALD GUNTHER \& KaTHLEEN SULLIVAN, CONSTITUTIONAL LAW 421, 431 (13th ed. 1997); AKHIL REED AMAR, THE BILL OF RIGHTS: CREATION AND RECONSTRUCTION 21213 (1998) [hereinafter AMAR, BILL OF RightS]; MichaEL KENT CURTIS, No STATE SHALL ABRIDGE: THE FOURTEENTH AMENDMENT AND THE BLL OF RIGHTS 175 (1986) [hereinafter CURTTS, NO STATE]; Akhil Reed Amar, The Bill of Rights and the Fourteenth Amendment, 101 YALE L.J. 1193, 1258 (1992) [hereinafter Amar]; Richard L. Aynes, Constricting the Law of Freedom: Justice Miller, the Fourteenth Amendment, and the Slaughter-House Cases, 70 CHI.-KENT L. REv. 627, 653-55 (1994) [hereinafter Aynes, Miller]; Michael Kent Curtis, Resurrecting the Privileges or Immunities Clause and Revising the Slaughter-House Cases Without Exhuming Lochner: Individual Rights and the Fourteenth Amendment, 38 B.C. L. REV. 1, 71 n.249, 86 (1996) [hereinafter Curtis, Resurrecting].

13 See 2 WILLIAM WINSLOW CROSSKEY, POLTIICS AND THE CONSTITUTION IN THE HISTORY OF THE UNTTED STATES 1128-30 (1953) [hereinafter CROSSKEY, POLITICS]; JOHN HART ELY, DEMOCRACY AND DISTRUST: A THEORY OF JUDICIAL REVIEW 196-97 n.59 (1980); Robert C. Palmer, The Parameters of Constitutional Reconstruction: Slaughter-House, Cruikshank, and the Fourteenth Amendment, 1984 U. ILL. L. REV. 739; Kevin Christopher Newsom, Setting Incorporationism Straight: A Reinterpretation of the Slaughter-House Cases, 109 YALE L.J. 643 (2000); Wildenthal, Lost Compromise, supra note 9; see also Laurence H. Tribe, The Supreme Court, 1998 Term: Comment-Saenz Sans Prophecy: Does the Privileges or Immunities Revival Portend the Future-or Reveal the Structure of the Present?, 113 HARV. L. REV. 110, 182-84 \& $\mathrm{nn} .326,331$ (1999) [hereinafter Tribe, Saenz] (citing Newsom's then-forthcoming article); 1 LAURENCE H. TRIBE, AMERICAN CONSTITUTIONAL LAW § 7-3, at 1307 (3d ed. 2000) [vol. 1 hereinafter TRIBE 2000; vol. 2 is not yet published] (citing Ely and Palmer). 
the decision. ${ }^{14}$ The article's other major new contributions to the scholarship were to demonstrate the further support for this theory to be found in the SlaughterHouse briefs, ${ }^{15}$ and in the fact that Slaughter-House was contemporaneously read in an incorporationist light by members of Congress across the political spectrum in $1873-74.16$

Indeed, for a brief time in the early 1870 s, incorporation appears to have been accepted as a minimum consensus reading of both the Fourteenth Amendment and Slaughter-House-a reading embraced alike by Democrats and Republicans, Southerners and Northerners, reactionaries and radicals. ${ }^{17}$ That potential consensus, however, was undermined and seemingly rejected by the Supreme Court in a series of decisions from 1874 to $1880:{ }^{18}$ Edwards $v$. Elliott, ${ }^{19}$ Walker v. Sauvinet, ${ }^{20}$ United States v. Cruikshank, ${ }^{21}$ Davidson v. New Orleans, ${ }^{22}$ and Missouri v. Lewis. ${ }^{23}$

This article takes up the early understanding on incorporation after 1880 . It revisits the process of argument, briefing, and decisionmaking in the Supreme Court by which the majority's conclusion in Twining, emphatically rejecting incorporation, "c[a]me to be firmly established." 24 Like the previous article, it reassesses a history that has been profoundly misunderstood. Also like its predecessor, it does so in part by resorting to careful examination of the briefs and arguments by lawyers before the Court, a resource previously underused by scholars. 25

In particular, this article seeks to correct the errors and misinterpretations of the prior leading scholarly account of this case law, Professor Stanley Morrison's 1949 Stanford Law Review article. ${ }^{26}$ That article, along with its famous companion article

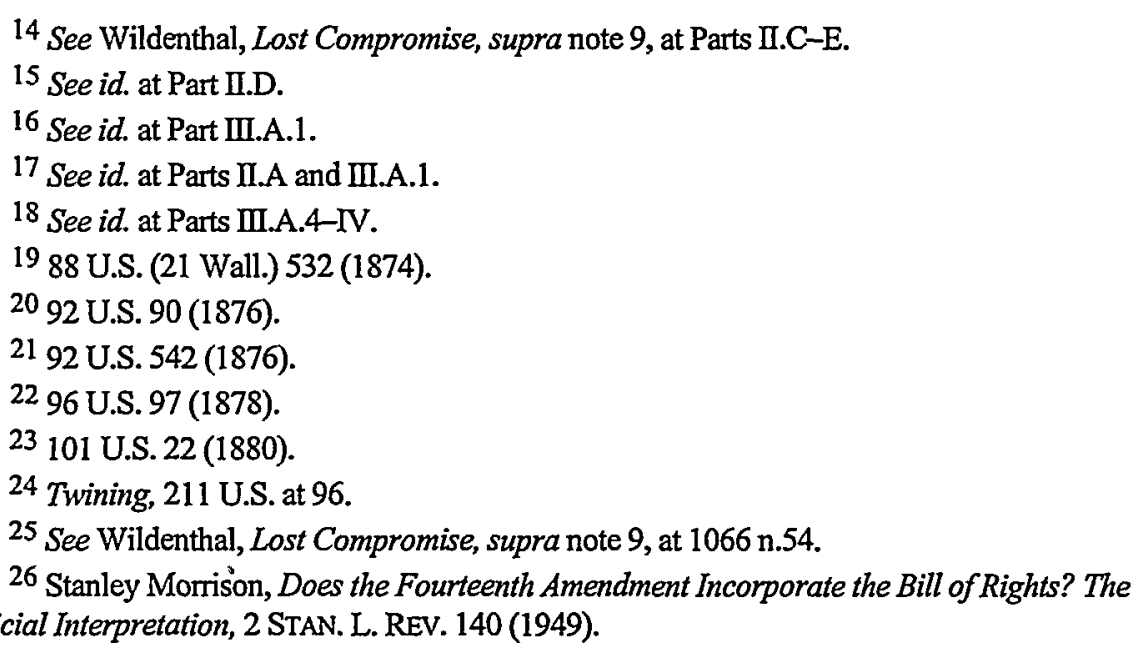


by Professor Charles Fairman, ${ }^{27}$ responded to Justice Hugo L. Black's 1947 dissent in Adamson v. California ${ }^{28}$ by attacking incorporation as a radical "afterthought.'29 As summarized in this author's previous article, Fairman's account of the original understanding of the Fourteenth Amendment during its framing and ratification in 1866-68 has been thoroughly discredited by scholars such as Professor William Winslow Crosskey, Professor Michael Kent Curtis, Professor Akhil Reed Amar, and Dean Richard Aynes. ${ }^{30}$

The previous article began the task of examining and refuting Professor Morrison's account of the post-ratification understanding and judicial interpretation of the Fourteenth Amendment. ${ }^{31}$ This article completes that task. In so doing, it also builds upon and cements the modern scholarly repudiation of Fairman's thesis. ${ }^{32}$ It should place the incorporation theory on a stronger foundation in the modern Supreme Court, which recently signalled, in Saenz $v . R o e, 33$ a willingness to reexamine the Privileges and Immunities Clause after its near-total dormancy during the first 130 years of the Amendment's history. Let the story now continue.

27 Charles Fairman, Does the Fourteenth Amendment Incorporate the Bill of Rights? The Original Understanding, 2 STAN. L. REV. 5 (1949).

28332 U.S. 46, 68-123 (1947) (Black, J., joined by Douglas, J., dissenting); see also id. at 123-25 (Murphy, J., joined by Rutledge, J., dissenting).

${ }^{29}$ See Morrison, supra note 26, at 152; see also id. at 143-57; Fairman, supra note 27, at 56, 134-39.

30 See Wildenthal, Lost Compromise, supra note 9, at Part I.B. The key stages in the scholarly demolition of Fairman's thesis were Crosskey's unjustly underrated and long-ignored 1954 article, see William Winslow Crosskey, Charles Fairman, "Legislative History," and the Constitutional Limitations on State Authority, 22 U. CHI. L. REV. 1, 2-119 (1954) [hereinafter Crosskey], Curtis's 1986 book (the most important work on the subject, which synthesized a series of his articles beginning in 1980), see CURTIS, No STATE, supra note 12, Amar's 1992 article, see Amar, supra note 12, and Aynes's 1993 article, see Richard L. Aynes, On Misreading John Bingham and the Fourteenth Amendment, 103 YALEL.J. 57 (1993) [hereinafter Aynes, Bingham].

31 See, e.g., Wildenthal, Lost Compromise, supra note 9, at Part I.A (summarizing key errors in Morrison's article); id. at Part II.D (criticizing Morrison's treatment of Slaughter-House).

32 See, e.g., infra Part II.B (discussing Hurtado v. California, 110 U.S. 516 (1884), and problems raised by issue of incorporating right to grand jury indictment); infra Part $\mathrm{V}$ (summarizing overall conclusions to be drawn from evidence analyzed in this article and its predecessor).

33 526 U.S. 489 (1999); see also Wildenthal, Lost Compromise, supra note 9, at Part I.A; infra Part V. 


\section{THE $1880 \mathrm{~s}$}

Looking... to the purpose in view in adopting this Fourteenth Amendment, and to the historic condition of things which suggested it ... I cannot think that we can go wrong in holding, as a canon for its true construction, that it shall have a liberal interpretation in favor of personal rights and liberty. If the views of the minority of the court in the Slaughter-House Cases be adopted, the argument I shall present would only be the stronger, but I shall rest upon that of the majority.... ${ }^{34}$

\section{A. Justice Harlan's Arrival on the Scene}

The first case after 1880 to implicate the issue of incorporation was Hurtado v. California, ${ }^{35}$ which provoked one of Justice John Marshall Harlan's many impassioned dissents. ${ }^{36}$ Hurtado was the first battle in Harlan's campaign-which lasted through almost all of his thirty-four-year tenure on the Court, from 1877 to 191137-to restore the incorporation of the Bill of Rights in the Fourteenth Amendment. He inevitably dominates this article's narrative.

Justice Harlan is most famous, of course, for his legendary dissent in Plessy $v$. Ferguson, ${ }^{38}$ protesting the Court's upholding of state-mandated racial segregation in transportation. That his progressive vision of the law extended much farther has not always been fully appreciated. Any general study of his legal philosophy would outrun the scope of this article. But his contribution to the incorporation issue should be placed in the context of his overall judicial career and approach to the law.

After a long drought of writing on Harlan's life, two excellent general biographies finally appeared in the $1990 \mathrm{~s} .{ }^{39}$ The most insightful study of his legal philosophy, however, is Professor Linda Przybyszewski's book, The Republic According to John Marshall Harlan. ${ }^{40}$ Harlan adopted the Republican Party as his omitted).

34 Spies v. Ilinois, 123 U.S. 131, 150 (1887) (argument of John Randolph Tucker) (citation

35110 U.S. 516 (1884).

36 Id. at 538-58 (Harlan, J., dissenting).

37 See THE OXFORD COMPANION TO THE SUPREME COURT OF THE UNITED STATES 968 (Kermit L. Hall ed. 1992) [hereinafter OXFORD SUPREME COURT] (table of Justices and their tenures).

38 163 U.S. 537, 552-64 (1896) (Harlan, J., dissenting).

39 LOREN P. BETH, JOHN MARSHALL HARLAN: THELAST WHIG JUSTICE(1992); TINSLEY E. YARBROUGH, JUDICIAL ENIGMA: THE FIRST JUSTICE HARLAN (1995).

40 LINDA PRZYBYSZEWSKJ, THE REPUBLIC ACCORDING TO JOHN MARSHALL HARLAN (1999) [hereinafter PRZYBYSZEWSKI]. Przybyszewski's study actually predates Beth's and Yarbrough's books, see supra note 39, originating as a 1989 Ph.D. dissertation. See Linda C.A. Przybyszewski, 
political affiliation after the Civil War, but more important to his judicial career was his commitment to an idealized vision of civic republicanism. This philosophy involved, for Harlan, a strong belief in equal opportunity, individual liberty and a corresponding work ethic, vigorous citizen participation in democratic institutions, and a deep aversion to the arrogance and injustice of unearned privilege, whether claimed by European aristocrats or American White supremacists. ${ }^{41}$

A lawyer and politician from Kentucky, Harlan and his family owned slaves, and although he was a staunch Unionist during the Civil War, he strongly opposed emancipation and-most ironically-the very Thirteenth and Fourteenth Amendments he would spend much of his judicial career defending. ${ }^{42}$ That he was able to travel from such a background to his stirring 1896 evocation in Plessy of a "color-blind" Constitution under which "all citizens are equal before the law" 43 is part of his enduring mystique. Praising Harlan's Plessy dissent has become a cliché-and attention should be paid to its troubling aspects ${ }^{44}$-but it has deservedly become one of the canonical documents of American political and legal mythology, on a par with Jefferson's Declaration of Independence, Lincoln's Gettysburg Address, and the Constitution itself.

At its best, Harlan's writing achieved poetic eloquence, not to mention prophetic insight, as in his comment that "[t] he destinies of the two races, in this country, are indissolubly linked together, and the interests of both require that the common government of all shall not permit the seeds of race hate to be planted under the sanction of law."45 In his avowal that "[ $[$ ] he humblest [citizen] is the peer

The Republic According to John Harlan Marshall: Race, Republicanism, and Citizenship (Ph.D. dissertation, Stanford Univ., 1989) [hereinafter Przybyszewski Diss.]. It is one of the most intriguing and inspiring accounts ever written on the formation and expression of any judge's legal philosophy and work product. And Harlan, of course, was not just any judge, but a judicial giant whose life spanned, in storybook fashion, some of the most wrenching and formative aspects and years of American life and history. Given such praise and the coincidence that Professor Przybyszewski and I received degrees from the same university in the same year, it is perhaps appropriate to add that I have never met her. I originally cited only Przybyszewski's dissertation because I completed much of this article before the publication of her book. Because the book substantially modifies the dissertation in certain ways, I now cite to both the book and the dissertation, as appropriate.

41 See PRZYBYSZEWSK, supra note 40, at 81-117, 185-202; Przybyszewski Diss., supra note 40 , at 77-88, 311-22.

42 See BETH, supra note 39, at 25-80; YARBROUGH, supra note 39, at 3-64; PRZYBYSZEWSKI, note 40, at 14-43; Przybyszewski Diss., supra note 40, at 1-52.

43 Plessy, 163 U.S. at 559 (Harlan, J., dissenting).

${ }^{44}$ See infra note 58.

45 Plessy, 163 U.S. at 560 (Harlan, J., dissenting). 
of the most powerful," and that "[t]he law regards man as man," 46 can be heard the echo of the Scottish bard of democracy:

Is there, for honest poverty, [a man] That hangs his head, and a' that? .. What though on hamely fare we dine, Wear hodden gray, and a' that; Gie fools their silks, and knaves their wine, A man's a man for a' that! ... Ye see yon birkie, ca'd a lord, Wha struts, and stares, and a' that;... The man of independent mind, He looks and laughs at a' that! ... For a' that, and a' that, It's comin' yet for a' that, That man to man, the warld o'er, Shall brothers be for a' that! ${ }^{47}$

An intriguing personal angle is added by evidence that, indeed, Justice Harlan had an African-American half-brother, Robert James Harlan. As a slave, Robert Harlan grew up and was educated (illegally at the time) in the Harlan household. He made his fortune in the California gold fields and purchased his freedom. After the Civil War, he became a prominent Ohio Republican with whom Justice Harlan maintained cordial communications, although their relationship was never publicly acknowledged. 48

46 Id. at 559.

47 RoBert BURNs, Is There, For Honest Poverty (1795), in THE COMPLETE POETICAL WORKS OF ROBERT BURNS 482-83 (Edinburgh: W.P. Nimmo, 1878). Unfortunately, in Bums's and Harlan's time, the law also regarded woman as woman. See, e.g., Bradwell v. Illinois, 83 U.S. (16 Wall.) 130, 139-42 (1873) (Bradley, J., joined by Swayne and Field, JJ., concurring in the judgment) (agreeing, in remarkably patemalistic terms, with denial of woman's claim of admission to practice of law); PRZYBYSZEWSKI, supra note 40, at 187 (noting Harlan's lack of sympathy for women's access to legal profession). Equality under the law without regard to sex (or, for example, sexual orientation) lay beyond even Harlan's far-seeing vision, though not beyond the full sweep of the principles he articulated. See, e.g., Romer v. Evans, 517 U.S. 620, 623 (1996) (invoking Harlan's Plessy dissent, two days after its one hundredth anniversary, to open first Supreme Court majority opinion ever to strike down, under Equal Protection Clause, mistreatment of gay and lesbian people).

48 See BETH, supra note 39, at 12-13 (noting uncertainty whether Robert's father was Justice Harlan's father or grandfather; Robert's mother, Mary Harlan, was a slave belonging to the Harlans; Robert eventually settled in Cincinnati and became active in Republican politics, including service in the Ohio legislature); YARBROUGH, supra note 39, at 10-11 (evidence supports conclusion that Robert and Justice Harlan were half-brothers); id. at 11-20, 141 (describing Robert's life, career, and contacts with Harlan and his family, including an 1871 incident involving an assault by a White Harlan relative on a Black justice of the peace in Washington, D.C., in which the future Justice Harlan enlisted Robert's assistance in handling the delicate racial issues involved); see also PRZYBYSZEWSKI, supra note 40, at 23-24, 112-13; Przybyszewski Diss., supra note 40, at 21-23; James Gordon, Did the First Justice Harlan Have $a$ Black Brother?, 15 W. NEW ENG. L. REV. 159 (1993). Among the acquaintances Robert and Justice Harlan shared were African-American leader Frederick Douglass and future President William Howard Taft; the latter grew up on the same Cincinnati street where Robert lived and was 
As early as 1883, Justice Harlan was dissenting alone, in a scathing opinion, from the Court's decision striking down the Civil Rights Act of 1875 and its mandate of racially integrated public accommodations. ${ }^{49}$ Near the end of his career, in 1908, he assailed with undiminished passion his home state's enforcement of racial apartheid in private education. ${ }^{50}$ In that and other racially charged cases, he remained, in his seventies, more progressive than such younger, Northern, and reputedly liberal twentieth-century colleagues as Justice Oliver Wendell Holmes, Jr. 51

Harlan's vision of freedom and equal rights extended to Native Americans, 52 to sailors protesting archaic maritime laws holding them in virtual bondage, ${ }^{53}$ and

a boyhood schoolmate of Robert's son, Robert Harlan, Jr., who became a lawyer and a lifelong supporter and correspondent of Taft. See YARBROUGH, supra note 39, at 14-17, 141-42.

${ }^{49}$ See Civil Rights Cases, 109 U.S. 3, 26-62 (1883) (Harlan, J., dissenting).

50 See Berea College v. Kentucky, 211 U.S. 45, 58-70 (1908) (Harlan, J., dissenting). As Harlan poignantly asked:

Have we become so inoculated with prejudice of race that an American government, professedly based on the principles of freedom, and charged with the protection of all citizens alike, can make distinctions between such citizens in the matter of their voluntary meeting for innocent purposes simply because of their respective races?

Id. at 69.

51 See, e.g., Giles v. Harris, 189 U.S. 475, 493-504 (1903) (Harlan, J., dissenting from decision finding federal courts powerless to remedy massive disfranchisement of AfricanAmerican voters in Alabama); Clyatt v. United States, 197 U.S. 207, 222-23 (1905) (Harlan, J., dissenting alone from majority's reversal of conviction for returning African-Americans to peonage); Bailey v. Alabama, 211 U.S. 452, 455-59 (1908) [hereinafter Bailey I] (Harlan, J., dissenting from Court's refusal on jurisdictional grounds to grant relief to victim of peonage); Bailey v. Alabama, 219 U.S. 219 (1911) [hereinafter Bailey II] (Harlan, J., joining decision finally granting relief to same litigant as in Bailey I). Holmes concurred in the judgment (without opinion) in Berea College, 211 U.S. at 58, joined the majority opinion in Clyatt, wrote the Court's opinions in Giles and Bailey I, and wrote an appallingly insensitive dissent in Bailey II, see 219 U.S. at 24550 (Holmes, J., joined by Lurton, J., dissenting).

52 See Elk v. Wilkins, 112 U.S. 94, 110-23 (1884) (Harlan, J., joined by Woods, J., dissenting) (protesting majority's denial of U.S. citizenship and voting rights to Native American born in U.S. who had left his tribe and settled in Omaha, Nebraska, pointing out that majority's reasoning created "a despised and rejected class of persons, with no nationality whatever"); PRZYBYSZEWSKI, supra note 40, 118-20 (discussing Elk and Harlan's sympathy for Native Americans, but also noting that Harlan "shared racial myth that Native Americans were a doomed people").

${ }^{53}$ See Robertson v. Baldwin, 165 U.S. 275, 288-303 (1897) (Harlan, J., dissenting) (vehemently protesting, as violation of Thirteenth Amendment's ban on slavery and involuntary servitude, majority's upholding of federal statutes under which sailors in private employment who "jumped ship" prior to expiration of their contracts of service could be arrested and incarcerated pending ship's sailing, and forcibly returned to service aboard ship, with no trial or hearing). 
to the peoples of conquered overseas territories claiming that "the Constitution follow [s] the flag." 54 He also took a broad view of federal and state authority to enact progressive social and economic reforms, dissenting from the more egregious applications of substantive due process, ${ }^{55}$ from the Court's invalidation of the federal income tax, ${ }^{56}$ and from the Court's weakening, as he saw it, of the scope and rigor of federal antitrust laws. ${ }^{57}$

54 PRZYBYSZEWSKI, supra note 40, at 137; see also, e.g., Downes v. Bidwell, 182 U.S. 244, 375-91 (1901) (Harlan, J., dissenting); Hawaii v. Mankichi, 190 U.S. 197, 226-49 (1903) (Harlan, J., dissenting) (protesting majority's refusal to enforce unqualified federal constitutional right to jury trial in then-territory of Hawaii); Dorr v. United States, 195 U.S. 138, 154-58 (1904) (Harlan, J., dissenting) (same as to Philippines). In what amounted to a thunderous denunciation of the theory and practice of colonialism, Justice Harlan declared in Mankichi that, if the majority's reasoning were taken to its logical conclusion,

the time may not be far distant when, under the exactions of trade and commerce, and to gratify an ambition to become the dominant political power in all the earth, the United States will acquire territories in every direction, which are inhabited by human beings, over which territories, to be called "dependencies" or "outlying possessions," we will exercise absolute dominion, and whose inhabitants will be regarded as "subjects" or "dependent peoples," to be controlled as Congress may see fit, not as the Constitution requires, nor as the people governed may wish. Thus will be engrafted upon our republican institutions, controlled by the supreme law of a written Constitution, a colonial system entirely foreign to the genius of our government and abhorrent to the principles that underlie and pervade the Constitution.

Mankichi, 190 U.S. at 240 (Harlan, J., dissenting). See generally PRZYBYSZEWSKI, supra note 40, at 122-46 (exploring seeming paradox of Harlan's initial support of Spanish-American War and his opposition to manner in which American colonial rule was extended); Przybyszewski Diss., supra note 40 , at $251-310$ (same).

55 See, e.g., Lochner v. New York, 198 U.S. 45, 65-74 (1905) (Harlan, J., joined by White and Day, JJ., dissenting from majority's invalidation of state law limiting bakery employment to ten-hour day and sixty-hour week). Harlan did not, however, reject the theory of substantive due process. See, e.g., Adair v. United States, 208 U.S. 161 (1908) (Harlan, J., for the Court) (striking down federal statutory prohibition of "yellow dog" anti-union railroad employment contracts); Smyth v. Ames, 169 U.S. 466 (1898) (Harlan, J., for the Court) (striking down state regulation of railroad rates); see also YARBROUGH, supra note 39, at 180-82.

56 Pollock v. Farmers' Loan and Trust Co., 158 U.S. 601, 638-86 (1895) (Harlan, J., dissenting). Harlan's dissent in this case was vindicated by constitutional amendment in 1913, just two years after his death. See U.S. CONST. amend. XVI.

57 See, e.g., United States v. E.C. Knight Co., 156 U.S. 1, 18-46 (1895) (Harlan, J., dissenting from majority's conclusion that sugar trust, and manufacturing generally, as allegedly distinct from interstate commerce, were exempt from Sherman Antitrust Act of 1890); Standard Oil Co. v. United States, 221 U.S. 1, 82-106 (1911) (Harlan, J., concurring in part and dissenting in part) (agreeing with majority's dissolution of monopoly but dissenting from adoption of "rule of reason" in interpreting Antitrust Act). In his Standard Oil dissent (his last significant opinion), Harlan commented that " $[t]$ here are some who say that it is a part of one's liberty to conduct commerce among the States without being subject to governmental authority. But that would not 
Harlan had his inconsistencies and failings. In several important cases, he failed to rise above the racial attitudes of his time. ${ }^{58}$ But in so doing, he fell short of a standard that he alone on that Court had set in the first place. In an oppressively racist era, it was the magnificent reach of his aspirations, and the extent to which he did live up to them, that stand out.

be liberty, regulated by law, and liberty, which cannot be regulated by law, is not to be desired." Standard Oil, 221 U.S. at 105 (Harlan, J., concurring in part and dissenting in part).

58 For example, Justice Harlan wrote the opinion for a unanimous Court in Cumming v. Richmond County Board of Education, 175 U.S. 528 (1899), denying injunctive relief sought by African-Americans regarding closure of a segregated Black high school in a locality where the segregated White high school remained open. Procedural quirks enabled Harlan and his colleagues to dodge, on rather hair-splitting grounds, the fundamental issue of racial segregation in public education. See PRZYBYSZEWSKI, supra note 40, at 99-102, 117; Przybyszewski Diss., supra note 40, at 161-69. Earlier, Harlan had silently joined Justice Field's unanimous opinion for the Court in Pace v. Alabama, 106 U.S. 583 (1883), upholding a more severe criminal punishment for adultery when the participants were of different races. Pace was overruled by McLaughlin $v$. Florida, 379 U.S. 184 (1964). See also Loving v. Virginia, 388 U.S. 1 (1967); PRZYBYSZEWSKI, supra note 40, at 109-16; Przybyszewski Diss., supra note 40, at 150-53. An important recent article has also pointed to Harlan's disturbingly illiberal and anti-egalitarian record (notably worse in some cases than some of his nineteenth-century colleagues on the Court) in cases affecting citizens and aliens of Chinese ancestry. See Gabriel J. Chin, The Plessy Myth: Justice Harlan and the Chinese Cases, 82 IowA L. REV. 151 (1996). Professor Chin, for example, discussed the oftenoverlooked language in Harlan's Plessy dissent referring to "a race so different from our own that we do not permit those belonging to it to become citizens of the United States[:] ... the Chinese race." Plessy, 163 U.S. at 561 (Harlan, J., dissenting). Compare United States v. Wong Kim Ark, 169 U.S. 649, 652-705 (1898) (holding that Fourteenth Amendment Citizenship Clause applies to persons born in United States to Chinese parents), with id. at 705-32 (Fuller, C.J., joined by Harlan, J., dissenting). See also Chin, supra, at 156-59. More widely noted has been Harlan's troubling comment in Plessy:

The white race deems itself to be the dominant race in this country. And so it is, in prestige, in achievements, in education, in wealth and in power. So, I doubt not, it will continue to be for all time, if it remains true to its great heritage and holds fast to the principles of constitutional liberty.

Plessy, 163 U.S. at 559 (Harlan, J., dissenting) (emphasis added). Professor Przybyszewski argued that this language, paradoxically, reflected Harlan's ultimate devotion to egalitarian and meritocratic principles, because it was premised, not on any inherent racial entitlement, but on adherence to republican principles that themselves, as Harlan promptly spelled out, required classless equality before the law. "But in view of the Constitution, in the eye of the law, there is in this country no superior, dominant, ruling class of citizens. There is no caste here. Our Constitution is color-blind ... [etc.]." Id. (emphasis added); see also PRZYBYSZEwSKI, supra note 40, at 95-99; Przybyszewski Diss., supra note 40, at 316-17. There is, regrettably, no similar salvaging interpretation of Harlan's anti-Chinese stance. I disagree with Professor Chin's conclusion that Harlan's entire vision of equality under law is consequently discredited, see Chin, supra, at 156-57, 171-82, but reconciling Harlan's capitulation to racism in the Chinese and other cases with his overall philosophy and career is a task better left to some future article. 


\section{B. Hurtado and the Grand Jury Problem}

The Court's 1884 decision in Hurtado upheld, by a seven-to-one vote, a capital conviction for murder following prosecution by information rather than grand jury indictment. ${ }^{59}$ Justice Stephen J. Field did not participate. ${ }^{60}$ Joseph Hurtado, the defendant, invoked neither total incorporation as a broad theory nor the Privileges and Immunities Clause, ${ }^{61}$ presumably because of their poor batting average up to that time. Nor did he argue that the federal Fifth Amendment grand jury right ${ }^{62}$ was literally "incorporated" in the Fourteenth Amendment. His argument, instead, was that forsaking grand jury indictment violated the essential meaning of due process, which of course is expressly guaranteed by both Amendments. ${ }^{63}$ In effect, this amounted to an argument for selective incorporation via the Due Process Clause, the type of argument that would meet with frequent success by the 1960s. ${ }^{64}$

Justice Harlan's dissent, foreshadowing his similar protest sixteen years later in Maxwell v. Dow, ${ }^{65}$ reflected his special reverence for the institution of the jury in all its forms. ${ }^{66}$ His debate with Justice Stanley Matthews, who wrote for the majority, revolved mainly around the weight to be given to historical English

59 Hurtado v. California, 110 U.S. 516, 538 (1883).

${ }^{60}$ Id. at 558; see also Wildenthal, Lost Compromise, supra note 9, at Parts II.C-D and III.BIV (discussing Field's views, or lack thereof, on incorporation prior to Hurtado).

61 The only reference to that clause in Hurtado came when the majority quoted the passage in Walker v. Sauvinet, 92 U.S. 90 (1876), holding both that civil jury trial was not an inherent element of due process and that it was not a privilege or immunity of United States citizenship. Hurtado, 110 U.S. at 533 (quoting Walker, 92 U.S. at 92-93).

62 U.S. CONST. amend. V ('No person shall be held to answer for a capital, or otherwise infamous crime, unless on a presentment or indictment of a Grand Jury ....").

${ }^{63}$ See Hurtado, 110 U.S. at 519-20; Brief for Plaintiff in Error [i.e., Hurtado, the defendant at trial] at 5-6, Hurtado v. California, 110 U.S. 516 (1884) [hereinafter Hurtado Defendant's Brief]. The Supreme Court briefs in Hurtado are reprinted in 8 LANDMARK BRIFFS AND ARGUMENTS OF THE SUPREME COURT OF THE UNITED STATES: CONSTITUTIONAL LAW 395-475 (Philip B. Kurland \& Gerhard Casper eds. 1975).

${ }^{64}$ See, e.g., Duncan v. Louisiana, 391 U.S. 145 (1968). Hurtado suggested the broader implications of incorporation in contending that

the Federal Constitution does not by express language secure a person against an arrest by State authority without a warrant, nor... the right to be informed of the nature of the offense, to a speedy trial, the right to appear by counsel, or to trial by jury, and yet no one would dare to deny that these things are secured by the Fourteenth Amendment, because they constituted a part of due process of law at the time of its adoption.

Hurtado Defendant's Brief, supra note 63, at 34.

65176 U.S. 581, 605-17 (1900) (Harlan, J., dissenting); see also infra Part IV.

66 See PRZYBYSZEWSKI, supra note 40, at 163-67; Przybyszewski Diss., supra note 40, at 199-250. 
practice in construing the scope of "due process of law."67 Matthews refused to be bound by ancient practices thought to give that phrase determinate content as a legal term of art. In a fascinating foretaste of twentieth-century debates between Justices Hugo Black and Felix Frankfurter, Matthews rejected the idea that due process had "by immemorial usage . . . acquired a fixed, definite, and technical meaning . . .."68 Rather, it was concerned with "[a]rbitrary power... whether manifested as the decree of a personal monarch or of an impersonal multitude." 69

It follows that any legal proceeding enforced by public authority, whether sanctioned by age and custom, or newly devised in the discretion of the legislative power, in furtherance of the general public good, which regards and preserves these principles of liberty and justice, must be held to be due process of law. ${ }^{70}$

Harlan took issue with this approach in words whose spirit would be strikingly echoed many years later by Black:

It is said by the court that the Constitution... was made for an undefined and expanding future, and that ... due process ... must be so interpreted as not to deny to the law the capacity of progress and improvement.... It is difficult, however, to perceive anything in the system of prosecuting human beings for their lives, by information, which suggests that the State which adopts it has entered upon an era of progress and improvement in the law of criminal procedure. ${ }^{71}$

Many modern lawyers familiar with how the criminal justice system actually operates would side with the Hurtado majority and against Justice Harlan on the

67 Compare Hurtado, 110 U.S. at 521-32 (opinion of the Court), with id. at 539-47, 549-56 (Harlan, J., dissenting).

$68 \mathrm{Id}$. at 521 .

$69 \mathrm{Id}$. at 536.

${ }^{70}$ Id. at 537. Cf. Adamson v. Califomia, 332 U.S. 46, 67 (1947) (Frankfurter, J., concurring):

A construction which gives to due process no independent function but turns it into a summary of the specific provisions of the Bill of Rights would... deprive the States of opportunity for reforms in legal process designed for extending the area of freedom. It would assume that no other abuses would reveal themselves in the course of time than those which had become manifest in 1791.

71 Hurtado, 110 U.S. at 553. Cf. Duncan v. Louisiana, 391 U.S. 145, 170 (1968) (Black, J., concurring):

I am not bothered by the argument that applying the Bill of Rights to the States... prevent[s] States from trying novel social and economic experiments. I have never believed that under the guise of federalism the States should be able to experiment with the protections afforded our citizens through the Bill of Rights. 
utility of the grand jury. Instead of that time-honored but practically ineffective check on prosecutors, criminal defendants themselves might well prefer "the proceeding by information, after examination and commitment by a magistrate, certifying to the probable guilt of the defendant, with the right on his part to the aid of counsel, and to the cross-examination of ... witnesses." 72 As California's attorney in Hurtado asked, "What accused would exchange an open examination before a committing magistrate for a secret inquisition into his offenses?"73

Harlan, however, was not just clinging to the grand jury out of old-fashioned attachment to traditional procedures. As Professor Przybyszewski has explained, the jury, in both its grand and petit forms, held for Harlan a uniquely important role as a democratic lay institution in his civic republican vision-a barrier of the common people between the individual and officers of the state, whether judges or prosecutors. ${ }^{74}$ That a criminal defendant might actually prefer to take his chances with a magistrate rather than a group of his fellow citizens would not have carried much weight with Harlan. ${ }^{75}$

The most notorious analytical gambit of the Hurtado majority was its argument from superfluity: that because the Fifth Amendment expressly guarantees both due process and grand jury indictment, the latter is outside the scope of either the Fifth or Fourteenth Amendment Due Process Clauses. ${ }^{76}$ This redundancy argument, echoing the Court's 1878 suggestion in Davidson v. New Orleans that the right of just compensation was not part of due process, ${ }^{77}$ flew in the face of the Court's earlier opinion in Murray's Lessee v. Hoboken Land and Improvement $\mathrm{Co}^{78}$ That 1856 case held that in deciding whether a given procedure "is due process[]... [w] must examine the constitution itself, to see whether this process

72 Hurtado, 110 U.S. at 538.

${ }^{73}$ Brief for Defendant in Error [Califomia] at 20, Hurtado v. Califomia, 110 U.S. 516 (1884).

74 See PRZYBYSZEWSKI, supra note 40, at 164-65; Przybyszewski Diss., supra note 40, at 202-04, 210-14, 247-50.

${ }^{75} C f$. Przybyszewski Diss., supra note 40, at 203 (noting that Harlan's “idealized vision of the workings of a jury led him to underestimate how whites could turn the criminal justice system into a means of racial oppression"). "When Harlan dissented in Hurtado, he proclaimed his devotion to the people's participation in their government. The individual defendant's stake in the outcome of a jury trial is an obvious one. The people's interest[,] while less immediately apparent[] was equally important to him." Id. at 249-50.

${ }^{76}$ Hurtado, 110 U.S. at 534-35.

77 See Davidson v. New Orleans, 96 U.S. 97, 105 (1878); see also Hurtado, 110 U.S. at 533-35 (quoting and discussing Davidson and Missouri v. Lewis, 101 U.S. 22 (1880)); Wildenthal, Lost Compromise, supra note 9, at Part IV (discussing Davidson and Lewis).

7859 U.S. (18 How.) 272 (1856). 
be in conflict with any of its provisions."79 The Murray's Lessee Court, quite untroubled by the notion of constitutional superfluity, noted, for example, that the Sixth Amendment right to a criminal jury trial is largely redundant to the original Constitution's guarantee that "[t]he Trial of all Crimes, except in Cases of Impeachment, shall be by Jury ...."80

Murray's Lessee implied that at least all procedural guarantees in the Bill of Rights are properly incorporated in the concept of due process, entirely apart from the Privileges and Immunities Clause. 81 One can, of course, take the view that "due process" embraces at least all procedural guarantees important enough to be specified in the Constitution, and yet also agree with Justice Frankfurter that it is "[not] confined to them. The Due Process Clause... has an independent potency ... ."82 Justice Black's view that the Due Process Clause has no procedural content apart from other specific provisions of the Bill of Rights was a troubling and unnecessary outgrowth of his total incorporation theory. ${ }^{83}$ The second Justice John Marshall Harlan, an ally of Frankfurter in opposing incorporation, quite emphatically believed that "due process is a discrete concept which subsists as an independent guaranty of liberty and procedural fairness, more general and inclusive than the specific prohibitions [of the Bill of Rights]."84

It is, of course, one of the great ironies of American constitutional history that the elder Justice Harlan's views on incorporation found vindication with Justice Black but not with his own grandson, Black's longtime friend and colleague on the

79 Id. at 277.

${ }^{80}$ U.S. CoNST. art. III, § 2, cl. 3; Murray's Lessee, 59 U.S. (18 How.) at 276. The Hurtado majority acknowledged Murray's Lessee, but misconstrued it to mean merely

that a process of law, which is not otherwise forbidden, must be taken to be due process of law, if it can show the sanction of settled usage both in England and in this country; but it by no means follows that nothing else can be due process of law.

Hurtado, 110 U.S. at 528. Au contraire, it is clear from the cited passage in Murray's Lessee that "a process of law" which is "otherwise forbidden" by the Constitution (as prosecution for capital or infamous crimes absent grand jury indictment is) cannot be "due process of law."

81 See CURTIS, No STATE, supra note 12, at 166, 174; Amar, supra note 12, at 1225-26; Crosskey, supra note 30, at 6-7.

82 Adamson, 332 U.S. at 66 (Frankfurter, J., concurring).

83 Cf. In re Winship, 397 U.S. 358, 377-86 (1970) (Black, J., dissenting); ELY, supra note 13, at 20-21. Justices Frank Murphy and Wiley B. Rutledge had the right idea in Adamson: "Occasions may arise where a proceeding falls so far short of conforming to fundamental standards of procedure as to warrant constitutional condemnation in terms of a lack of due process despite the absence of a specific provision in the Bill of Rights." 332 U.S. at 124 (Murphy, J., joined by Rutledge, J., dissenting); see also Wildenthal, Lost Compromise, supra note 9, at 1059 n.25.

84 Poe v. Ullman, 367 U.S. 497, 542 (1961) (Harlan, J., dissenting). 
Court. ${ }^{85}$ Yet, while differing on the incorporation issue, grandfather and grandson were very much in tune in rejecting Black's limitation on the procedural scope of due process. Responding to the Hurtado majority's redundancy argument, the elder Harlan objected that

too much stress is put upon the fact that the framers of the Constitution made express provision for the security of [certain] rights ... and, in addition, declared, generally, that no person shall "be deprived of life, liberty or property without due process of law." The rights, for... which... express provisions were made, were of a character so essential ... that it was deemed wise to avoid the possibility that Congress ... would impair or destroy them. Hence, their specific enumeration in the earlier amendments of the Constitution, in connection with the general requirement of due process of law, the latter itself being broad enough to cover every right of life, liberty or property secured by the settled usages and modes of proceedings existing under the common and statute law of England at the time our government was founded. 86

The Court-in an opinion written, appropriately enough, by the elder Justice Harlan-politely ignored the Hurtado redundancy argument in the 1897 case that inaugurated the practice of selective incorporation via the Due Process Clause. ${ }^{87}$ Harlan's response to the argument in Hurtado, relying in part on Murray's Lessee, ${ }^{88}$ dramatically presaged his debate with future majorities over incorporation of the rest of the Bill of Rights. The majority's logic, he said,

would require it to be likewise held that the right not to be put twice in jeopardy of life and limb, for the same offense, nor compelled in a criminal case to testify against one's self... were not protected by ... due process of law.... More than that, other amendments of the Constitution ... expressly recognize the right of persons to just compensation for private property taken for public use; their right, when accused of

85 See YARBROUGH, supra note 39, at 226 (noting Black's friendship with younger Harlan and that Black displayed elder Harlan's portrait in his chambers). Justice Black was even "convinced that the Blacks and Harlans were distant relations." Id. Black was born in 1886 in a tiny Alabama hamlet called Harlan, and was delivered by a cousin of his named Dr. John J. Harlan. See GERALD T. DUNNE, Hugo BLACK AND THE JudiCIAL REvolution 85-89 (1977); ROGER K. NEWMAN, HUGO BLACK: A BIOGRAPHY 3 (1994).

${ }^{86}$ Hurtado, 110 U.S. at 550 (Harlan, J., dissenting).

87 See Chicago, Burlington \& Quincy R.R. Co. v. Chicago, 166 U.S. 226, 241 (1897); infra Part III.B; see also CURTIS, No STATE, supra note 12, at 189 ("no 'canon' of constitutional construction is more regularly and correctly ignored than the doctrine of nonsuperfluousness ... announced in Hurtado").

${ }^{88}$ See Hurtado, 110 U.S. at 542 (Harlan, J., dissenting) (quoting Murray's Lessee, 59 U.S. (18 How.) at 276-77); see also Hurtado Defendant's Brief, supra note 63, at 28 (same). 
crime, to ... trial, by an impartial jury ... [and] to be confronted with the witnesses against them.... Are they to be excluded... . ? 89

Yes, the Court would later hold, as to all but one of the rights just mentioned. Harlan would live to see most of his parade of horribles come true. ${ }^{90}$

In a technical sense, Hurtado sheds no light on what any of the Justices thought about incorporation under the Privileges and Immunities Clause, since that issue was not raised or addressed. ${ }^{91}$ But it is troubling that Justices Joseph P. Bradley and William B. Woods, who both supported incorporation in the early $1870 \mathrm{~s},{ }^{92}$ joined the majority opinion. They denied relief to a defendant in a capital case who invoked the Fourteenth Amendment, and whose claim would have been undeniable under the incorporationist consensus prevailing just ten years earlier.

Professor Morrison argued that in light of Hurtado, Justice Harlan's later support for incorporation via the Privileges and Immunities Clause was a mere "afterthought."93

This [Hurtado] opinion of ... Harlan is of particular interest because 16 years later he became the great exponent ... of ... incorporat[ion] .... But in 1884 it apparently did not occur to him to place this interpretation upon the Amendment. This is all the more noteworthy because... Harlan had intense feelings upon the issue in ... Hurtado .... If at that time he had supposed that the Fourteenth Amendment could legitimately be construed to incorporate the Bill of Rights as such, it is incredible that he should not have said so. The express terms of the Fifth Amendment [Grand Jury

\section{${ }^{89}$ Hurtado, 110 U.S. at 547-48 (Harlan, J., dissenting).}

90 The exception was the right of just compensation. See supra note 87; infra Part III.B (discussing Chicago B\&Q); see also infra Part IV and note 303 (discussing Maxwell v. Dow, 176 U.S. 581 (1900) (disincorporating right to jury trial), West v. Louisiana, 194 U.S. 258 (1904) (disincorporating right of confrontation), and Twining v. New Jersey, 211 U.S. 78 (1908) (disincorporating privilege against self-incrimination)). Harlan did not live to see the Court's fulfillment of his warning that it would disincorporate the rule against double jeopardy, see Palko v. Connecticut, 302 U.S. 319 (1937), nor did he have what would have been the sweeter satisfaction of witnessing its eventual decisions to overnule Maxwell, West, Twining, and Palko in, respectively, Duncan v. Louisiana, 391 U.S. 145 (1968), Pointer v. Texas, 380 U.S. 400 (1965), Malloy v. Hogan, 378 U.S. 1 (1964), and Benton v. Maryland, 395 U.S. 784 (1969).

91 See Newsom, supra note 13, at 723-26 (discussing Hurtado).

92 See Wildenthal, Lost Compromise, supra note 9, at Part II.A (discussing Woods's support for incorporation as federal circuit judge, see, e.g., United States v. Hall, 26 F. Cas. 79, 81-82 (C.C.S.D. Ala. 1871), and Bradley's support for incorporation in private correspondence with Woods); id. at Part II.D (discussing Bradley's incorporationist dissent in Slaughter-House, 83 U.S. (16 Wall.) at 118-19 (Bradley, J., joined by Swayne, J., dissenting)); id. at Part III.C (discussing Bradley's incorporationist circuit court opinion in United States v. Cruikshank, 25 F. Cas. 707, 714-15 (C.C.D. La. 1874), aff'd on other grounds, 92 U.S. 542 (1876)).

93 Morrison, supra note 26, at 152. 
Clause] would have settled the matter and would have made unnecessary the exhaustive researches into the historical meaning of due process ... by ... the majority, as well as by ... Harlan himself. ${ }^{94}$

In fact, it was only eight years later, not sixteen, that Harlan explicitly embraced total incorporation via the Privileges and Immunities Clause. ${ }^{95}$ More to the point, there is nothing "incredible" about his failure to do so in Hurtado, if one takes seriously the idea that judges should only pass upon the issues brought before them. 96

Justice Harlan did in fact rely, quite emphatically, on the "express terms" of the Fifth Amendment Grand Jury Clause to support his view of the Fourteenth Amendment Due Process Clause. ${ }^{97}$ Furthermore, while it is true that reliance on incorporation via the Privileges and Immunities Clause would have made it unnecessary to consider whether grand jury indictment was a procedure inherent in due process, the reverse is equally true. Harlan had no need to address the Privileges and Immunities Clause because he would have granted all the relief requested under the Due Process Clause. Professor Morrison seemed to think due process was the more difficult issue, but it clearly was not for Harlan. For Harlan to address the Privileges and Immunities Clause would not only have been needless judicial activism on his part, 98 it would have required equally if not more "exhaustive researches" into the true meaning and tangled construction of that clause in cases like Slaughter-House, Walker, and Cruikshank. ${ }^{99}$

Hurtado provides a useful juncture to consider one of the modern arguments against total incorporation: that it is simply inconceivable that those who framed and adopted the Fourteenth Amendment meant to fasten on the states the supposed

94 Id. at $146-47$.

95 See O'Neil v. Vermont, 144 U.S. 323, 370 (1892) (Harlan, J., dissenting); infra Part III.A.

${ }^{96} \mathrm{It}$ is hombook law-and goes to the very essence of judicial power and restraint in the American tradition, including our courts' traditional aversion to advisory opinions-that a court generally will not, and should not, address an issue abandoned or never raised before it, see Phillips v. Wash. Legal Found., 526 U.S. 156, 164 n.4 (1998) (noting that "it would be improper for us sua sponte to raise and address" a question not raised by parties before Court); see also, e.g., Posters 'N' Things, Ltd. v. United States, 511 U.S. 513, 527 (1994); Helicopteros Nacionales de Colombia, S.A. v. Hall, 466 U.S. 408, 415 n.10 (1984); Russell v. United States, 369 U.S. 749, $754 \mathrm{n} .7$ (1962); Newsom, supra note 13, at 726-27 n.410, with rare exceptions such as the court's own lack of subject-matter jurisdiction, see, e.g., Louisville \& Nashville R.R. Co. v. Mottley, 211 U.S. 149, 152 (1908). As the Court stated in Yakus v. United States, 321 U.S. 414, 444 (1944), "No procedural principle is more familiar ... than that a constitutional right may be forfeited in criminal as well as civil cases by the failure to make timely assertion of the right...."

97 See Hurtado, 110 U.S. at 546 (Harlan, J., dissenting).

98 Morrison himself noted that the issue was not raised. See Morrison, supra note 26, at 147.

${ }^{99}$ See generally Wildenthal, Lost Compromise, supra note 9. 
"strait jacket"100 of the Bill of Rights, most notably the grand and civil jury requirements. By the mid-twentieth century, many if not most states, exploiting the leeway allowed by Walker and Hurtado, had abandoned or modified the practices of grand jury indictment and civil jury trial in ways forbidden to the federal government under the Fifth and Seventh Amendments. Justice Frankfurter scornfully argued in 1947 that "[e]ven the boldest innovator would shrink from suggesting to more than half the States that they may no longer initiate prosecutions without indictment by grand jury, or that thereafter all the States of the Union must furnish a jury of twelve for every case involving a claim above twenty dollars."101

But the historical evidence collected by Justice Frankfurter himself in a later case $^{102}$ helps to demonstrate that applying the entire Bill of Rights to the stateseven including the grand and civil jury requirements-would not have been viewed as a radical or unduly disruptive "innovation" in 1868, when the Fourteenth Amendment was ratified. Of the thirty-seven states in the Union at that time, all but one guaranteed civil jury trial as a matter of state constitutional right, in a manner at least substantially in accord with the Seventh Amendment. ${ }^{103}$

There was, it is true, more divergence with regard to the grand jury. Still, twenty-three states in 1868-nearly two-thirds-guaranteed grand jury indictment in full accordance with the Fifth Amendment. ${ }^{104}$ To be sure, the grand jury lost

${ }^{100}$ Cf. Adamson v. California, 332 U.S. 46, 89 (1947) (Black, J., dissenting) ("I cannot consider the Bill of Rights to be an outworn 18th Century 'strait jacket' as the Twining opinion did.").

${ }^{101}$ Id. at 64-65 (Frankfurter, J., concurring); see also, e.g., Fairman, supra note 27, at 82-84, 137-38; Charles Fairman, A Reply to Professor Crosskey, 22 U. CHI. L. REV. 144, 155 (1954) [hereinafter Fairman, Reply].

102 See Bartkus v. Illinois, 359 U.S. 121, 140-49 (1959) (appendix to opinion of the Court by Frankfurter, J.).

103 See Wildenthal, Lost Compromise, supra note 9, at 1146 \& nn.438-439.

104 See ALA. CONST. of 1867 , art. I, $\S 10$, reprinted in 1 SOURCES AND DOCUMENTS OF UNITED STATES CONSTITUTIONS 82 (William F. Swindler ed. 1973-79) [hereinafter ST. CONST.]; ARK. CONST. of 1868, art. I, $\S 9$, reprinted in 1 ST. CONST., supra, at 382; CAL. CONST. of 1849, art. I, $\S 8$, reprinted in 1 ST. CONST., supra, at 447-48; DEL. CONST. of 1831, art. I, $\S 8$, reprinted in 2 ST. CONST., supra, at 217; FLA. CONST. of 1868, art. I, § 9, reprinted in 2 ST. CONST., supra, at 353; ILL. CONST. of 1848, art. XIII, $\S 10$, reprinted in 3 ST. CONST., supra, at 267; IowA CONST. of 1857 , art. I, $\S 11$, reprinted in 3 ST. CONST., supra, at 452; KY. CONST. of 1850, art. XIII, $\S 13$, reprinted in 4 ST. CONST., supra, at 183; ME. CoNST. of 1819, art. I, $\$ 7$, reprinted in 4 ST. CONST., supra, at 315; MISS. CONST. of 1868, art. I, $\$ 31$, reprinted in 5 ST. CONST., supra, at 378; MO. CONST. of 1865 , art. I, $\$ 24$, reprinted in 5 ST. CONST., supra, at 517; NEB. CONST. of 1867 , art. I, $\S 8$, reprinted in 6 ST. CONST., supra, at 151 ; NEV. CONST. of 1864 , art. I, $\S 8$, reprinted in 6 ST. CONST., supra, at 264; N.J. CONST. of 1844, art. I, $\$ 9$, reprinted in 6 ST. CONST., supra, at 454 ; N.Y. CONST. of 1846, art. I, $\$ 6$, reprinted in 7 ST. CONST., supra, at 192; N.C. CONST. of 1868 , art. I, $\S 12$, reprinted in 7 ST. CONST., supra, at 415; OHIO CONST. of 1851, art. I, § 10, reprinted in 7 ST. CONST., supra, at 559; PA. CONST. of 1838, art. IX, $\S 10$, reprinted in 8 ST. 
ground thereafter. Many states were modernizing their criminal justice systems around this time, and dispensing with the grand jury was a common step. California itself, for example, from which Hurtado arose, had fully guaranteed grand jury indictment in 1868 , but shifted to prosecution by information in 1879 , after the judicial evisceration of the Privileges and Immunities Clause had largely been accomplished. 105

This would all seem to say more about attitudes toward the grand jury in particular than about incorporation in general. Of the twenty-four specific privileges and immunities articulated in the Bill of Rights, ${ }^{106}$ all or almost all states complied

CONST., supra, at 303; R.I. CONST. of 1842, art. I, $\$ 7$, reprinted in 8 ST. CONST., supra, at 387; S.C. CONST. of 1868, art. I, \$ 19, reprinted in 8 ST. CONST., supra, at 495; TENN. CONST. of 1834, art. I, $\S 14$, reprinted in 9 ST. CONST., supra, at 153; W. VA. CONST. of 1863 , art. II, $\S 1$, reprinted in 10 ST. CONST., supra, at 342; WIS. CONST. of 1848, art. I, $\S 8$, reprinted in 10 ST. CoNST., supra, at 419. A twenty-fourth state guaranteed grand jury indictment in all criminal cases where the potential punishment was death or life imprisonment. See CONN. CONST. of 1818, art. I, $\S 9$, reprinted in 2 ST. CoNST., supra, at 145. There was no correlation between whether a state guaranteed grand jury in 1868 and whether it ratified the Fourteenth Amendment by 1868 . Of the foregoing twenty-four states that guaranteed some type of grand jury indictment, twenty ratified by 1868 (Alabama, Arkansas, Connecticut, Florida, Mlinois, Iowa, Maine, Missouri, Nebraska, Nevada, New Jersey, New York, North Carolina, Ohio, Pennsylvania, Rhode Island, South Carolina, Tennessee, West Virginia, and Wisconsin), and four did not (California, Delaware, Kentucky, and Mississippi). Of the thirteen states not guaranteeing any type of grand jury indictment, ten ratified by 1868 (Georgia, Indiana, Kansas, Louisiana, Massachusetts, Michigan, Minnesota, New Hampshire, Oregon, and Vermont), and three did not (Maryland, Texas, and Virginia). See Bartkus, 359 U.S. at 140-45 (listing states in July 1868 proclamation of ratification of Amendment).

105 Compare CAL. CONST. of 1849 , art. I, $\S 8$ (guaranteeing grand jury), reprinted in 1 ST. CONST., supra note 104, at 447-48, with CAL. CONST. of 1879 , art. I, $\$ 8$ (replacing grand jury with information), reprinted in $1 \mathrm{ST}$. CONST., supra note 104, at 470 . Cf. Fairman, supra note 27 , at 98-100 (noting that Illinois Constitution of 1870 allowed legislative abolition of grand jury).

106 These may be numbered as follows: (1) rule against establishment of religion, (2) free exercise of religion, (3) freedom of speech, (4) freedom of the press, (5) right of peaceable assembly, (6) right of petition, see U.S. CONST. amend. I, (7) right to keep and bear arms, see id. amend. II, (8) freedom from quartering of soldiers, see id. amend. III, (9) search, seizure, and warrant guarantees, see id. amend. IV, (10) right to grand jury indictment, (11) immunity from double jeopardy, (12) privilege against self-incrimination, (13) right to just compensation for private property taken for public use, see id. amend. V, (14) right to speedy trial, (15) right to public trial, (16) right to impartial jury trial within state and district where crime was allegedly committed, (17) right to be informed of nature and cause of accusation, (18) right to be confronted by adverse witnesses, (19) right of compulsory process to obtain favorable witnesses, (20) right to counsel, see id. amend. VI, (21) right to common law civil jury trial, see id. amend. VII, (22) immunity from excessive bail, (23) immunity from excessive fines, and (24) immunity from cruel and unusual punishments, see id. amend. VIII. The right to due process of law, see id. amend. V, is of course not at issue because the Fourteenth Amendment incorporates that specifically, see id. amend. XIV, § 1. See also Wildenthal, Lost Compromise, supra note 9, at 1077 n.90. 
in 1868 - at least in principle and on paper-with all twenty-three other than grand jury indictment. ${ }^{107}$ Given the political imperatives for Republicans supporting ratification of the Fourteenth Amendment, it is doubtful whether anyone considered or cared much about the relatively minor particulars in which some states were not already in conformity with the Bill of Rights. ${ }^{108}$ That could have been worked out by litigation or legislation.

There is an air of unreality about Professor Fairman's argument that, if the Fourteenth Amendment had been understood to incorporate the entire Bill of Rights, opponents would have used that as political ammunition. ${ }^{109} \mathrm{He}$ even went so far as to describe the prospect of enforcing the Bill of Rights against the states

107 Justice Frankfurter and Professor Fairman argued that several states in 1868 deviated in certain other ways (apart from the grand jury issue) from exact conformity with the Bill of Rights, but the evidence consisted mostly of minor (in some cases debatable) inconsistencies with certain aspects of Sixth or Seventh Amendment jury trial rights. Cf. Bartkas, 359 U.S. at 140-45 (Frankfurter, J.) (Georgia, New Hampshire, Massachusetts, and Michigan deviating in certain respects from precise federal practice of criminal trial by jury of twelve); Faiman, supra note 27, at 82 (Connecticut not expressly guarding against double jeopardy, nor New Hampshire against invasion of freedom of speech, though Fairman did not suggest that either state approved of violating such principles and conceded that "[o]ne can easily imagine that [they] would have seen no objection to abiding by the federal Bill of Rights in those respects"); id. at 86-87 (New Hampshire not abiding by rule against establishment of religion); id. at 88 (New Jersey arguably not fully in conformity with Seventh Amendment, by allowing trial by jury of six men in civil cases); id. at 102 (Nevada arguably not fully in conformity with Seventh Amendment, by allowing three-fourths majority verdicts in civil cases); $i d$. at 122-23 (Nebraska arguably not fully in conformity with Seventh Amendment, by allowing "trial by a jury of a less number than twelve men, in inferior courts"); id. at 127-28 (Georgia arguably not fully in conformity with Sixth and Seventh Amendment jury trial rights).

108 See CURTIS, No STATE, supra note 12, at 185; Amar, supra note 12, at 1246-54; Crosskey, supra note 30, at 111-12; see also Michael Zuckert, Book Review, 8 CONST. COMM. 149, 160-61 (1991) (reviewing RAOUL BERGER, THE FOURTEENTH AMENDMENT AND THE BILL OF RIGHTS (1989), CURTIS, NO STATE, supra note 12, and ROBERT J. KACZOROWSKI, THE POLITICS OF JUDICIAL INTERPRETATION: THE FEDERAL COURTS, DEPARTMENT OF JUSTICE AND CIVIL RIGHTS, 1866-1876 (1985)) (noting minor nature of inconsistencies with Bill of Rights and that "all this happened long before the Warren Court began to interpret the Bill of Rights in ways that did indeed challenge many of the prerogatives to which the states had become accustomed"). The political imperatives supporting readmission of "reconstructed," pro-Republican southern states, in order to boost Republican strength in Congress, tend to undermine the significance of the few deviations from the Bill of Rights scholars have pointed to in the constitutions adopted by several such states (often in conjunction with their coerced ratification of the Fourteenth Amendment) and approved by Congress upon readmission. Compare, e.g., Fairman, supra note 27, at 126-32, and JAMES E. BOND, NO EASY WALK TO FREEDOM: RECONSTRUCTION AND THE RATIFICATION OF THE FOURTEENTH AMENDMENT 45, 111, 180-82, 220-21, 235-38, 252-62 (1997), with CURTIS, No STATE, supra note 12, at 131-56, Amar, supra note 12, at 1246-54, 1256 n.271, and Crosskey, supra note 30, at 85-88, 100-11.

${ }^{109}$ See Fairman, supra note 27, at 137-38; Fairman, Reply, supra note 101, at 155. 
as a "menace." 110 But as Professor Amar observed with refreshing common sense, "Who wants to campaign against the Bill of Rights?"111 In fact, enforcing the entire Bill of Rights against the states was regarded by even the most conservative Democrats who spoke to the issue in the early 1870 s as a minimalist position which they eagerly embraced. ${ }^{112}$ That the idea became a radical menace to some in the twentieth century is interesting, indeed strange, but has no bearing on the understanding in the nineteenth century.

Perhaps most peculiar is that Professor Fairman twice triumphantly emphasized, as if it supported his ultimate argument, that even Michigan, the home state of that arch-incorporationist, Republican Senator Jacob M. Howard, did not afford any right to grand jury indictment. ${ }^{113}$ Indeed, Howard had been Attorney General of Michigan years earlier when the state legislature abolished the grand jury and provided for prosecution by information. ${ }^{114}$ But what does that tell us? Certainly not that Howard opposed incorporation. He was more Catholic than the Pope on that issue. ${ }^{115} \mathrm{He}$ may have overlooked the detail of the grand jury, but whether he was aware of that conflict or not, he did not seem to care much about it, whereas it is obvious he cared very deeply about enforcing the Bill of Rights against the states as a general matter.

The example of Senator Howard, far from undermining the incorporationist understanding, tends to destroy any remaining significance that the grand jury or other variances between contemporary state practices and the Bill of Rights might be thought to have. It proves that it was likely that proponents of the Amendment were willing to accept possible changes in a few aspects of some states' civil or

110 Fairman, Reply, supra note 101, at 155. Dean Bond, in a recent echo of this Fairman argument, asserted: "Had the amendment's opponents suspected that the due process clause was a Trojan horse for the Bill of Rights, they would have attacked it venomously. After all, they speculated endlessly about the evil ends that the framers had allegedly concealed in other provisions of the amendment." BoND, supra note 108, at 252. Well, yes, but only if one presumes the dubious premise that enforcing the Bill of Rights against the states would have been understood by the public at large (or even the opponents of the Fourteenth Amendment themselves) as an "evil end."

111 Amar, supra note 12, at 1253.

112 See Wildenthal, Lost Compromise, supra note 9, at Part III.A.1.

113 See Fairman, supra note 27, at 115-16, 134.

114 See id. at 115-16.

115 See CONG. GLOBE, 39th Cong., 1st Sess. 2764-66 (May 23, 1866) (Howard's famous speech introducing Fourteenth Amendment in Senate); Wildenthal, Lost Compromise, supra note 9, at 1073-74. Fairman's only explanation for this supposed paradox was an ad hominem footnote essentially implying that Howard was a fuzzy-minded buffoon not to be taken seriously. See Fairman, supra note 27, at 134 n.381. But see Wildenthal, Lost Compromise, supra note 9, at 1072 n.73, 1074 n.81. 
criminal procedures, even in their own states-if they even thought about such issues-as the price of the greater imperatives at stake.

The fact that the states have now relied for more than a century on Walker and Hurtado to restructure their civil and criminal justice systems is a persuasive argument for granting those cases the respect of stare decisis. But it furnishes no ground to question the broader theory of incorporation via the Privileges and Immunities Clause. Bowing out of necessity to Walker and Hurtado does not undermine the legitimacy of the near-complete incorporation of the rest of the Bill of Rights that has properly, by now, been achieved.

\section{Slaughter-House Revisited and Presser}

Just two months after the Court decided Hurtado, it revisited Slaughter-House in Butchers' Union Slaughter-House and Live-Stock Landing Co. v. Crescent City Live-Stock Landing and Slaughter-House Co. (Slaughter-House II). ${ }^{116}$ Louisiana, in 1879 , had chosen to abolish the monopoly privileges that gave rise to the 1873 Slaughter-House decision. The Crescent City company, which had enjoyed that monopoly, brought suit claiming a violation of the Contract Clause. ${ }^{117}$ Justice Miller, again writing for the Court, upheld the 1879 repeal on the ground that the state could not contract away its inherent police power to regulate "public health and public morals." $18 \mathrm{He}$ had no occasion to say anything bearing on incorporation or the implications in that regard of his own 1873 opinion.

In Slaughter-House $I$, however, as in the earlier decision, Justice Miller spoke only for a bare majority of five. Justices Field and Bradley were still on the Court and their feelings had not mellowed with time. They reiterated in separate concurring opinions their 1873 dissenting views that the monopoly was an outrageous violation of natural and common law rights embodied in the Fourteenth Amendment. 119

116111 U.S. 746 (1884).

117 See id. at 746-49; U.S. CoNST. art. I, $\S 10$, cl. 1 ("No State shall ... pass any ... law impairing the obligation of contracts ....").

118 Slaughter-House II, 111 U.S. at 751. See generally id. at 749-54.

119 See id. at 754-60 (Field, J., concurring); id. at 760-66 (Bradley, J., joined by Harlan and Woods, JJ., concurring). Bradley found the repeal valid because the original monopoly was "against common right," id. at 761, and, more specifically, violated the Privileges and Immunities, Due Process, and Equal Protection Clauses of the Fourteenth Amendment, id. at 763-64. Field relied somewhat more generally on Section 1 of the Amendment, see id. at 758-59, and, like Bradley, emphasized the natural-law and common-law grounds, see id. at 754-58, of his conclusion that the monopoly was "against common right, and void," id. at 760. The influence of laissez-faire capitalist economic philosophy on Field's views was again, as in his 1873 SlaughterHouse dissent, quite evident. See id. at 757 (quoting ADAM SMITH, ANINQUIRY INTO THENATURE 
Justices Harlan and Woods replaced Chief Justice Salmon P. Chase and Justice Noah H. Swayne, by then gone from the Court, in siding with Justices Bradley and Field in Slaughter-House II. ${ }^{120}$ Woods had been on public record supporting incorporation since 1871, as a federal circuit judge, ${ }^{121}$ and Harlan, fresh from his dissent in Hurtado, would soon become the champion par excellence of that theory. ${ }^{122}$ That they chose to join the Slaughter-House II concurrence of Bradley, who explicitly endorsed incorporation in Slaughter-House itself, ${ }^{123}$ can only add to one's eagerness in scanning the Bradley and Field opinions in Slaughter-House $I I$ for any clues on incorporation. Alas, there are few if any.

Justices Bradley and Field both reiterated their criticisms of Justice Miller's 1873 Slaughter-House majority opinion, but neither found it necessary to address the Bill of Rights, since again it furnished no particular aid in condemning the disputed monopoly. ${ }^{124}$ Field thus remained, yet again, a sphinx on incorporation. Bradley did state that "I then held [in Slaughter-House], and still hold, that the [Privileges and Immunities Clause] has a broader meaning [than the 1873 majority gave it]; that it includes those fundamental privileges and immunities which belong essentially to the citizens of every free government ...."125 But while one might wish that this embraced by silent implication Bradley's explicit (and Miller's strongly implied) 1873 endorsement of incorporation, it must be balanced against Bradley's devastating silence in Walker, Cruikshank, and Hurtado, ${ }^{126}$ and his authorship of Missouri v. Lewis. 127

Unfortunately, whatever hope Slaughter-House II might have furnished that Justice Woods (at least) might adhere to the incorporation theory, was undermined just two years later. Woods wrote the unanimous opinion of the Court in Presser

AND CAUSES OF THE WEALTH OF NATIONS (1776)); see also Wildenthal, Lost Compromise, supra note 9 , at $1091 \mathrm{n} .152$.

120 See Slaughter-House II, 111 U.S. at 760-66 (Harlan and Woods, JJ., concurring with Bradley, J.).

121 See supra note 92.

122 See infra Parts III-IV.

123 See supra note 92.

124 See Slaughter-House II, 111 U.S. at 760 (Field, J., concurring); id. at 764 (Bradley, J., concurring). It is intriguing that Bradley criticized Miller's 1873 opinion for holding 'that the 'privileges and immunities of citizens of the United States' ... are only those privileges and immunities which were created by the Constitution of the United States, and grew out of it, or out of laws passed in pursuance of it," $i d$. at 764 (emphases added), and that Field included "the right to peaceably assemble and petition for redress of grievances" in his recap of Miller's 1873 list of protected privileges and immunities, $i d$. at 760 . But nothing came of these hints.

125 Id. at 764 (Bradley, J., concurring) (emphasis added).

126 See supra Parts I and II.B; Wildenthal, Lost Compromise, supra note 9, at Parts III.B-C.

127101 U.S. 22 (1880); see also Wildenthal, Lost Compromise, supra note 9, at Part IV. 
v. Illinois, ${ }^{128}$ which upheld the criminal conviction of a man for unlawfully participating in an armed paramilitary parade. In so doing, the Court rejected Hermann Presser's argument that the Illinois law in question violated his right to keep and bear arms under the Second and Fourteenth Amendments. ${ }^{129}$ The Court found it "clear that ... forbid[ding] bodies of men to associate together as military organizations, or to drill or parade with arms in cities and towns unless authorized by law, do[es] not infringe the right of the people to keep and bear arms." 130 The Court continued, citing Cruikshank: "But a conclusive answer... [is] that the [Second] [A]mendment is a limitation only upon the power of Congress and the National government, and not upon that of the States."131

It may be argued that the Second Amendment is uniquely unsuited to incorporation-and perhaps does not protect any freestanding individual rightbecause of its linkage of the right to bear arms with governmental maintenance of a "well regulated militia."132 The Presser Court, for example, suggested that a state would violate the Second Amendment only if it "prohibit[ed] the people from keeping and bearing arms, so as to deprive the United States of their rightful resource for maintaining the public security, and disable the people from

128 116 U.S. 252 (1886).

129 Presser's brief was poorly organized and written. He argued that the Illinois law under which he was convicted violated the Second Amendment itself, see Brief for Plaintiff in Error [i.e., Presser, the defendant at trial] at 9-10,31-36, Presser v. Illinois, 116 U.S. 252 (1886) [hereinafter Presser Defendant's Brief], and as a separate assignment of error, that it violated Section 1 of the Fourteenth Amendment, without specifying how and without expressly invoking any particular theory of incorporation, see id. at 10-11. His summary of his assignments of error cited the Second and Fourteenth Amendment claims together, however, see id. at 5, and the Fourteenth Amendment assignment followed immediately after that of the Second Amendment, see id. at 9 11. The state thus understood Presser to argue that the Second Amendment right to bear arms was incorporated via the Privileges and Immunities Clause of the Fourteenth. See Brief for Defendant in Error [Illinois] at 7-9, Presser v. Illinois, 116 U.S. 252 (1886) [hereinafter Presser State's Brief]; see also Presser Defendant's Brief, supra, at 44 (incorporating by reference and attaching Brief for Defendant in Error Peter J. Dunn[e] (filed by Lyman Trumbull), Dunne v. People, 94 Ill. 120 (1880) [hereinafter Dunne Brief]); id., at 10-11 (arguing that Privileges and Immunities Clause "secure[s] ... the right to keep and bear arms as part of the militia which Congress has the right to organize" and that "[t]his is a national right which the national government has the power and which is its duty to enforce"). Cf. Morrison, supra note 26, at 147 (erroneously stating that in Presser, "[t] $]$ he question does not seem to have been raised whether the Second Amendment had been made applicable to the states through ... the Fourteenth Amendment'); STEPHEN P. HALBROOK, FREEDMEN, THE FOURTEENTH AMENDMENT, AND THE RIGHT TO BEAR ARMS, 18661876, at 184, 196 \& n.9 (1998) (same, citing Morrison, supra note 26, at 147).

130 Presser, 116 U.S. at 264-65.

131 Id. at 265.

132 U.S. CONST. amend. II. 
performing their duty to the general government."133 The Court proceeded to reject Presser's Privileges and Immunities Clause claim, in part because he "was not a member of the organized volunteer militia of the State of Illinois, nor did he belong to the troops of the United States or to any organization under the militia law of the United States."134 Modern scholarship has cast doubt on whether Second Amendment rights may properly be limited in this fashion, although that important and interesting issue is beyond the scope of this article. ${ }^{135}$

Responding to Presser's somewhat ambiguous Fourteenth Amendment claim, the Court inferred that he also meant to argue a violation under the First Amendment, as incorporated into the Fourteenth, of "his right to associate with others as a military company." 136 Again citing Cruikshank, the Court reaffirmed its holding in that case that the right of peaceable assembly was not protected against state power, "except ... to perform the duties or exercise the privileges of citizens of the United States."137

We should not, perhaps, make too much of Presser, especially as to Justices, like Harlan, who merely joined silently in the opinion. The Court's decision seems ultimately to have turned not on the issue of incorporation but on a narrow reading of the rights sought to be incorporated. The incorporation theory is not necessarily inconsistent with the Court's conclusion, on the facts presented, that Presser's claimed "right ... to associate together as a military company or organization, or to drill or parade with arms, without ... an act of Congress or law of the State authorizing the same, is not an attribute of national citizenship."138 The Court found the state power in question "necessary to the public peace, safety and good order. To deny the power would be to deny the right of the State to disperse assemblages organized for sedition and treason, and the right to suppress armed mobs bent on riot and rapine."139

\section{Presser, 116 U.S. at 265.}

134 Id. at 266.

135 See Wildenthal, Lost Compromise, supra note 9, at 1152 \& n.471 (citing AMAR, BILL OF RIGHTS, supra note 12, at 46-63, 257-66, HALBROOK, supra note 129, and Koren Wai WongErvin, Note, The Second Amendment and the Incorporation Conundrum: Towards a Workable Jurisprudence, 50 HASTINGS L.J. 177 (1998)).

136 Presser, 116 U.S. at 267; see also supra note 129; Presser State's Brief, supra note 129, at 6 ("We submit that the right of the people to assemble even for a lawful purpose is not such a right as it is the duty of the general government to enforce. By the first amendment of the constitution Congress is merely prohibited from abridging that right.'); Dunne Brief, supra note 129 , at 11 (referring to both right to bear arms and right of peaceable assembly).

137 Presser, 116 U.S. at 267.

138 Id.

${ }^{139} \mathrm{Id}$. at 268. It is difficult, of course, to see why suppressing peaceable assemblies was "recessary" to these goals. The Court's repressive tone suggests a certain Gilded Age panic over 
It is certainly difficult, however, to square Justice Woods's authorship of Presser-especially in view of his silent concurrence in Hurtado-with any continued loyalty on his part to the incorporation theory. He appears to have acquiesced to cases like Cruikshank, Walker, Davidson, and Lewis, decided before he joined the Court in 1881. ${ }^{140}$ Of course, Justice Harlan also acquiesced on the facts of Presser, only to reassert his incorporationist views later. Would Justice Woods have done likewise in a case squarely raising the issue? We will never know. He died the year after Presser, after only six years on the Court. ${ }^{141}$

\section{John Randolph Tucker and the Spies Appeal}

Six months after Justice Woods's death, the Court considered an appeal in the politically sensational case of Spies v. Illinois. ${ }^{142}$ Spies, like Presser, arose from Chicago and, more generally, from the radical ferment then percolating around the country. August Spies and his seven codefendants were anarchists charged with conspiracy to commit murder in the Haymarket incident of May 4, 1886, in which a bomb, thrown by an unidentified person during an anarchist rally near Haymarket Square in Chicago, killed several police officers. ${ }^{143}$ Although Spies and two of his codefendants had spoken at the rally, ${ }^{144}$ and the defendants had generally engaged in revolutionary activism and writing, no plausible evidence ever connected them to the bombing or showed any conspiracy by them to kill or harm anyone. ${ }^{145}$ They were nevertheless convicted and all but one were sentenced to death. ${ }^{146}$ Following unsuccessful appeals to the Illinois and U.S. Supreme Courts, the suicide on death row of one of the defendants, and the commutation of two of the remaining death

the rising tide of worker and anarchist protests during this period. See L.H. LaRue, Constitutional Law and Constitutional History, 36 BUFF. L. REv. 373, 375-81, 386-91, 400-01 (1987) (discussing historical and social background of Presser, and of Spies v. Illinois, 123 U.S. 131 (1887), discussed infra Part II.D). See generally PAUL AVRICH, THE HAYMARKET TRAGEDY 55119 (1984) (discussing the rise of the anarchist movement).

140 See OXFORD SUPREME COURT, supra note 37, at 968.

141 See id.

142123 U.S. 131 (1887).

143 See AVRICH, supra note 139, at 181-239. Of the eight police officers who eventually died, and the sixty who were wounded, many were apparently shot by their fellow officers, who opened fire in a panic. Seven or eight civilians were also killed, and several dozen wounded, by police gunfire. See id. at 207-10. The bomb was thrown after police ordered dispersal of the rally, which had been peaceful up to that point and was in the process of winding down anyway. See id. at 205-06, 210-14.

144 See id. at 199-206.

145 See id. at 267-78.

146 Id. at 279. 
sentences by Illinois Governor Richard J. Oglesby, Spies and three of his codefendants were hanged on November $11,1887 .{ }^{147}$

In 1893, Illinois Governor John Peter Altgeld pardoned the three surviving Haymarket defendants on grounds that the trial, as historians have come to agree, was "a shameless travesty of justice."148 Among other problems, the trial judge and jury were hopelessly biased against the defendants, jury selection was rigged, the prosecutor was allowed to indulge in outrageous misconduct and to introduce inflammatory and irrelevant evidence focusing on the defendants' unpopular political views, and the trial judge authorized the jury to convict on the basis of a startlingly far-reaching and legally unfounded theory of conspiracy and accomplice liability. ${ }^{149}$ The defendants' petition to the U.S. Supreme Court in 1887 raised numerous claims, most notably that they had been denied, in violation of the Fourteenth Amendment, the right to trial by an impartial jury, ${ }^{150}$ the privilege against self-incrimination, ${ }^{151}$ the right to security from illegal searches and seizures, ${ }^{152}$ the rights of free speech and peaceable assembly, ${ }^{153}$ and the right to be informed of the nature and cause of the accusations against them. ${ }^{154}$

The Spies petition was presented first to Justice Harlan, who referred it to the full Court, 155 which agreed to hear oral argument on "whether any Federal questions were actually made and decided in the Supreme Court of [Illinois] ... [and] upon the character of those questions, so that we may determine whether ... to bring the case here for review." 156 In support of the petition, counsel for the defendants made the first systematic argument before the Court for total

147 See id. at 334-98.

148 Id. at 422. See generally id. at 415-27. Altgeld was assailed as an "anarchist," a "socialist," and an "apologist for murder" because of his principled action; his political career was destroyed as a result. JOHN F. KENNEDY, PROFILES IN COURAGE 233-34 (1956).

149 See AVRICH, supra note 139, at 260-78.

150 See Spies, 123 U.S. at 133-36; Petition of August Spies and Others for Writ of Error (filed by Moses Salomon, William P. Black, Roger A. Pryor, and John Randolph Tucker) at 2-14, Spies v. Mlinois, 123 U.S. 131 (1887) [hereinafter Spies Petition]. Although Black's and Tucker's full names do not appear on the petition, their full names are disclosed in AVRICH, supra note 139, at 250,334 .

151 See Spies, 123 U.S. at 136-38; Spies Petition, supra note 150, at 15-17.

152 See Spies, 123 U.S. at 138; Spies Petition, supra note 150, at 17-20.

153 See Spies, 123 U.S. at 139; Spies Petition, supra note 150, at 20-24.

154 See Spies, 123 U.S. at 140; Spies Petition, supra note 150, at 35-44.

155 See Spies, 123 U.S. at 142 (statement of Harlan, J.).

${ }^{156}$ Id. at 143 (statement of Waite, C.J.). 
incorporation of the Bill of Rights in the Fourteenth Amendment, invoking both the Due Process and Privileges and Immunities Clauses. ${ }^{157}$

The attorneys who presented this argument are as interesting as the argument itself. The lead trial attorney for the defendants was William P. Black, one of the most successful and prominent corporate lawyers in Chicago. Black was a Civil War hero who won the Medal of Honor at age nineteen, having volunteered for the Union Army despite being "[b]om in Kentucky, the son of a Presbyterian minister who supported the Confederacy."158 For the U.S. Supreme Court appeal, Black retained three other renowned lawyers whose lives were also profoundly affected by the Civil War, though in fascinatingly diverse ways.

The lead attorney on the appeal was John Randolph Tucker, who had just completed twelve years in Congress as a Democratic Representative from Virginia. ${ }^{159}$ Tucker was retained at the instigation of the first attorney Black hired for the appeal, Roger A. Pryor, "a prominent Wall Street lawyer, who had been a brigadier general in the Confederate army."160 Tucker was a states'-rights politician before and after the Civil War. He served as Attorney General of Virginia under the Confederacy and taught law at what is now Washington and Lee University from 1870 until his election to Congress in 1874, and then from 1887 until his death in 1897. He became dean of the law school in 1893 and was president of the American Bar Association in 1892-93. ${ }^{161}$

157 See id. at 143-55 (argument for petitioners of John Randolph Tucker); id. at 155-56 (argument for petitioners of Roger A. Pryor); id. at 157-59 (argument for petitioners of Benjamin F. Butler); Brief for Petitioners (filed by Moses Salomon, William P. Black, Roger A. Pryor, and John Randolph Tucker) at 2, Spies v. Ilinois, 123 U.S. 131 (1887) Thereinafter Spies Petitioners' Opening Brief]; Supplemental Brief for Petitioners (filed by Roger A. Pryor) at 1-18 (Due Process Clause), 18-23 (Privileges and Immunities Clause), Spies v. Illinois, 123 U.S. 131 (1887) [hereinafter Spies Petitioners' Supplemental Brief]. Pryor's "argumene" reprinted in the case report is apparently just a summary of his written brief. See Spies, 123 U.S. at 155-56; Spies Petitioners' Supplemental Brief, supra. Pryor did present oral argument to the Court in support of the petition on October 21, 1887, but no summary of that is provided in the case report. The main arguments took place on October 27 and 28, 1887, followed by the Court's decision on November 2, 1887. See Spies, 123 U.S. at 131, 143.

158 AVRICH, supra note 139, at 251. See generally id. at 250-52.

159 See CONGRESSIONAL QUARTERLY'S GUIDE TO U.S. ELECTIONS 1030, 1035, 1039, 1043, $1047,1051,1055$ (3d ed. 1994) [hereinafter U.S. ELECTIONS] (elected to House in 1874, 1876, $1878,1880,1882$, and 1884; did not run in 1886). In 1888 his son, Henry St. George Tucker, was elected to succeed him. The younger Tucker served in Congress from 1889 to 1897, and again from 1922 until his death in 1932. See id. at 1059, 1063, 1069, 1074; 19 DictIONARY OF AMERICAN BIOGRAPHY 33 (1936) [hereinafter DICT. AM. BIO.].

160 AVRICH, supra note 139 , at 334.

161 See AVRICH, supra note 139, at 334; CURTIS, No STATE, supra note 12, at 185-86; 19 DicT. AM. BIO., supra note 159, at 34-35; 21 AMERICAN NATIONAL BIOGRAPHY 898 (1999) [hereinafter AM. NAT'L BIO.]. His grandfather was St. George Tucker (1752-1827), an esteemed 
Tucker was regarded as one of the most distinguished constitutional lawyers of his day, 162 and has been described as "an old-fashioned, strict-constructionist, state-rights logician," who opposed Reconstruction and was a stickler for "applying the yard stick of constitutionality to every measure before Congress." $163 \mathrm{He}$ became known as "one of the ablest and most articulate representatives from the South,"164 serving as Chairman of the Ways and Means Committee in 1879-81 and Chairman of the Judiciary Committee in 1883-87. 165 "When friends expressed surprise at his defense of the Chicago anarchists, Tucker replied, ' $I$ do not defend anarchy. I defend the Constitution." "166

Rounding out the team on appeal, and an intriguing counterpart to the two former Confederates, was Black's fellow Union Army veteran, General Benjamin F. Butler. Butler was a flamboyant and iconoclastic progressive on economic issues and civil rights, favoring not only racial equality but also female suffrage and the eight-hour day. ${ }^{167} \mathrm{He}$ commanded African-American soldiers in the Civil War, administered New Orleans during Reconstruction, and by 1887 had served Massachusetts as both a Republican Congressman and a Democratic Governor, and had run for president in 1884 on the Greenback Party ticket. ${ }^{168}$ In Congress he was

Virginia judge and legal scholar who published a famous 1796 pamphlet advocating the gradual abolition of slavery, a major annotated edition of Blackstone's Commentaries for American lawyers, and "the first extended, systematic commentary on the [United States] Constitution" following its ratification. See Clyde N. Wilson, Foreword to ST. GEORGE TUCKER, VIEW OF THE CONSTITUTION OF THEUNTIED STATES WTTH SELECTED WRITINGS vii (Clyde N. Wilson ed., 1999) (1803); 19 DiCT. AM. BIO., supra note 159, at 34, 38-39.

162 See AVRICH, supra note 139, at 334.

16319 DICT. AM. BIO., supra note 159, at 35 (internal quotation marks omitted); see also CURTIS, No STATE, supra note 12, at 186; 21 AM. NAT'L BIO., supra note 161, at 898.

16421 AM. NAT'LBIO., supra note 161, at 898.

165 See BIOGRAPHICAL DICTIONARY OF THE AMERICAN CONGRESS: 1774-1996, at 1966 (1997).

166 CURTIS, No STATE, supra note 12, at 186; see also 19 DiCT. AM. B1O., supra note 159, at 35 .

167 See ERIC FONER, RECONSTRUCTION: AMERICA'S UNFINISHED REVOLUTION, 1863-1877, at $233,315,455,491-92,498-99,521-22,524,533-34,553-55$ (1988).

168 See AVRICH, supra note 139, at 334; see also FONER, supra note 167, at 45-48, 491-92, 524; U.S. ElECTIONS, supra note 159, at 1014, 1017, 1021, 1025, 1029, 1033 (elected to House as Republican in 1866,1868,1870,1872, and 1876, though defeated in Democratic landslide of 1874). Butler served as Governor of Massachusetts for one year in 1883-84 (Massachusetts govemors were elected to one-year terms until 1920), having been elected in 1882 on a combined Democratic, Greenback, and Labor Party ticket. Butler had previously run for governor in 1859 as a Democrat and in 1878 and 1879 on the "Butler Democratic and Republican" ticket. He was defeated for reelection in 1883. See U.S. ELECTIONS, supra note 159, at 649, 686, $1352-54$. 
an ardent advocate of a broad reading of the Fourteenth Amendment, acting as House manager of the Civil Rights Act of 1875.169

Tucker argued before the Court that the rights protected by the Privileges and Immunities Clause were "such as have their recognition in or guaranty from the Constitution of the United States."170 He reasoned that, "while the [first] ten Amendments, as limitations on power, only apply to the Federal government, and not to the States, yet in so far as they declare or recognize rights of persons, ... the Fourteenth Amendment as to such rights limits state power, as the ten Amendments had limited Federal power."171 Tucker's co-counsel Butler and Pryor concurred in separate arguments. ${ }^{172}$

169 See FONER, supra note 167, at 533-34; see also id. at 455, 491-92, 498-99, 524, 55355 .

170 Spies, 123 U.S. at 150 . The cited portion of the Spies case report, see id. at 143-55, reprints a presumably condensed version of Tucker's oral argument before the Court. The brief signed by Tucker did not elaborate on incorporation, only mentioning once, in general terms, the argument that "the privileges and immunities of petitioners as citizens of the United States, were abridged, contrary to the Fourteenth Amendment." Spies Petitioners' Opening Brief, supra note 157, at 2. The supplemental brief filed by Tucker's co-counsel Pryor elaborated somewhat further on the incorporationist interpretation of the Privileges and Immunities Clause:

What are the 'privileges and immunities of citizens of the United States,' in the sense of th[e] [Fourteenth] [A]mendment, has not yet been settled by exhaustive analysis or definite formula; but, by reference to the original amendments to the Constitution, we may discover, with infallible certainty, what are some of those rights and immunities; for when the Constitution of the nation enumerates certain rights and liberties as inherent and inviolable in its citizens-inviolable even by its own action-we may know that those rights and liberties constitute privileges and immunities of citizens of the United States.

Spies Petitioners' Supplemental Brief, supra note 157, at 18-19. See generally id. at 18-23. Tucker addressed the problem posed by the fact that Spies and one of the other Haymarket petitioners were not American citizens (Spies was German) by reasoning that whatever rights the Privileges and Immunities Clause secured to citizens of the United States were necessarily secured to aliens residing in the United States, since the Fourteenth Amendment also guaranteed that "no person shall be denied the equal protection of the laws." Spies, 123 U.S. at 153 (emphasis added by Tucker); see also id. at 159-61 (Butler arguing that Spies and the other non-U.S. citizen petitioner were protected by treaties with Germany and Great Britain); infra note 296.

171 Spies, 123 U.S. at 151.

172 See id. at 156 (Pryor's argument); id. at 157-59 (Butler's argument); Spies Petitioners' Supplemental Brief, supra note 157, at 18-23. Butler did not sign the petitioners' Supreme Court petition or either of their briefs. A fifth attorney for the petitioners, Moses Salomon, did sign the petition and the opening brief, but, like co-counsel Black, did not present oral argument to the Court. See Spies Petition, supra note 150; Spies Petitioners' Opening Brief, supra note 157; Spies Petitioners' Supplemental Brief, supra note 157. 
Scholars have read Tucker's argument in Spies in different ways. ${ }^{173}$ Professor Morrison, for example, read Tucker as advocating, not incorporation of the entire Bill of Rights, but only those parts of it securing rights deemed "fundamental."174 Tucker did state that the guarantees of the Bill of Rights constitute privileges and immunities of citizens of the United States "in so far as they secure and recognize fundamental rights-common law rights-of the man."175 But it appears that Tucker considered all the rights specified in the Bill of Rights to be, by definition, "fundamental." This is indicated by his statement, immediately following the language just quoted, that the Fourteenth Amendment encompasses all Bill of Rights provisions that "declare or recognize rights of persons." 176 This is also supported by his co-counsel Pryor's brief, which argued that, while the full scope of protected privileges and immunities "has not yet been settled by exhaustive analysis or definite formula,"177 one could, "by reference to the original amendments to the Constitution, ... discover, with infallible certainty,"178 what at least some of them were. " $[\mathrm{F}]$ or when the Constitution ... enumerates certain rights and liberties as inherent and inviolable in its citizens ... we may know that those rights and liberties constitute privileges and immunities of citizens of the United States."179

173 Notable discussions appear in CURTIS, No STATE, supra note 12, at 185-88, Amar, supra note 12 , at $1270-71$, Morrison, supra note 26 , at $147-48,172$ n.63, and Newsom, supra note 13 , at 709-12.

174 See Morrison, supra note 26, at 172 n.63.

175 Spies, 123 U.S. at 151.

176 Id. This limiting "filter" applied by Tucker, $c f$. Amar, supra note 12, at 1270, would simply seem to have recognized the fact that parts of the first ten amendments do not guarantee any specific personal rights, but rather, for example, state a cautionary rule of construction regarding rights not specified, see U.S. CONST. amend. IX, or reserve to the states and to the people powers not delegated to the federal government, see U.S. CONST. amend. X.

177 Spies Petitioners' Supplemental Brief, supra note 157, at 18.

178 Id. at 19.

179 Id.; see also supra note 170 . Tucker conceded that Walker, Hurtado, and Presser could be viewed as "contrary to this view," Spies, 123 U.S. at 152, but he at least purported to distinguish them-noting, for example, that Presser may be read to have rested primarily on a narrow reading of the federal rights sought to be incorporated, see Spies, 123 U.S. at 152; supra Part II.C. His attempt to distinguish Walker and Hurtado was less than convincing. See Spies, 123 U.S. at 152 (noting that Hurtado was "decided on a clause of the Fifth Amendment" and Walker on "the Seventh Amendment," while ignoring the fact that both cases turned primarily on the Court's interpretation of the Fourteenth Amendment, and Walker, specifically, on the Privileges and Immunities Clause); see also id. at 151-52 (citing Cruikshank but not acknowledging that case's anti-incorporationist implications-indeed, suggesting that it supported his incorporationist argument). Cf. Wildenthal, Lost Compromise, supra note 9, at Part WI.B (discussing Walker), Part III.C (discussing Cruikshank). As Professor Curtis pointed out in a conversation with me, Tucker, 
Professor Amar, by interesting contrast, cited Tucker as supporting his "refined" theory of incorporation, associating Tucker with Justice Bradley's approach to incorporation in Slaughter-House, and disassociating him from Justice Black's approach in Adamson. ${ }^{180}$ Tucker's approach to incorporation may well have been more "refined" than Black's, which had its problems, as discussed in Part II.B, regarding the scope of procedural due process. But in diametric opposition to Morrison, Amar may have implied too broad a scope for Tucker's incorporation argument. Tucker's argument seems aligned with Black's and deeply at variance with Bradley's, in that Bradley had refused quite emphatically in Slaughter-House to be limited by the textual scope of the Bill of Rights in defining protected Fourteenth Amendment privileges and immunities. ${ }^{181}$ Tucker, like Black, limited such privileges and immunities to those that "have their recognition in or guaranty from the Constitution."182 Tucker thus seems to have been, like Black and Justice Miller (at least in Slaughter-House), a textual incorporationist.

Indeed, what no scholar other than Newsom seems to have discussed is that Tucker relied heavily on the incorporationist reading of the Slaughter-House majority opinion. ${ }^{183}$ Tucker cited Slaughter-House at four different points to

with these citations, may simply have been fulfilling his ethical obligation to alert the Court to contrary precedent arguably on point. See infra note 183.

180 See Amar, supra note 12, at 1270-71.

181 See Wildenthal, Lost Compromise, supra note 9, at Part II.D.

182 Spies, 123 U.S. at 150; see also HuGO LAFAYETTE BLACK, A CONSTITUTIONAL FAITH 18-21, 34-42 (1968); Wildenthal, Lost Compromise, supra note 9, at Part II.C (discussing Black's textualist rationale for total incorporation). Pryor's brief, as discussed above, admittedly casts some doubt on this reading of Tucker, since Pryor seemed to suggest that constitutional text was an "infallibl[y] certai[n]" floor, but perhaps not a ceiling, for the scope of the Privileges and Immunities Clause. Tucker, however, did not sign Pryor's brief, and Pryor's implication of a possible supratextual scope for the clause was a far cry from Bradley's emphatic embrace of natural and nontextual rights. Pryor, after all, emphasized the importance of text, while Bradley (like Field in Slaughter-House) expressly disdained it. See Wildenthal, Lost Compromise, supra note 9, at Parts II.C-D (discussing Field's and Bradley's Slaughter-House dissents).

183 See Newsom, supra note 13, at 709-12 (discussing Tucker's argument in Spies). Newsom did not, however, discuss the anti-incorporationist views expressed in Tucker's 1899 treatise, discussed infra text accompanying notes 192-97. Professor Curtis stated that "[a]fter the decisions in the Slaughter-House Cases, Hurtado, and the rest, Tucker faced an uphill battle in Spies," CURTIS, No STATE, supra note 12, at 186, thus treating Slaughter-House, in accordance with the conventional view, as a barrier that Tucker had to overcome. Tucker did not so treat it. Curtis suggested in a conversation with me that this reflects Tucker's skill, brilliant lawyer that he was, in making lemonade from lemons (after all, he was ethically obliged to acknowledge Slaughter-House as precedent, see supra note 179). My parry would be that Slaughter-House was lemonade to begin with, and was only tumed to vinegar by later cases. 
support his argument. 184 He noted that "[i]f the views of the minority ... in the Slaughter-House Cases... be adopted, [my] argument... would only be the stronger, but I shall rest upon that of the majority ...."185 His argument that Fourteenth Amendment privileges and immunities are those that "have their recognition in or guaranty from the Constitution"186 closely paraphrased Justice Miller's reference in Slaughter-House to privileges and immunities that "owe their existence to the ... Constitution."187

Chief Justice Morrison R. Waite's unanimous opinion for the Court in Spies recited the settled rule that the Bill of Rights applies of its own force only to the federal government, citing many of the cases discussed in this article and its predecessor, including Twitchell, Edwards, Walker, Cruikshank, Davidson, and Presser. ${ }^{188}$ But the Court did not actually respond to Tucker's argument that the Fourteenth Amendment extended the Bill of Rights to the states. Rather, it held, following detailed but unconvincing analysis, that no violation of the asserted Bill of Rights guarantees themselves (even assuming them to be applicable) had been shown. ${ }^{189}$ It thus dismissed the petition for lack of jurisdiction. ${ }^{190}$ This cleared the way for a legal lynching of the Haymarket petitioners, and is undoubtedly one of the more shameful abdications in the Court's history of its ultimate responsibility to uphold the rule of law.

It is less surprising than it might seem at first blush that a states'-rights Democrat and former Confederate like Tucker would join forces on incorporation

184 See Spies, 123 U.S. at 149, 150, 151, 152. As Newsom pointed out, Tucker specifically cited the pages in Slaughter-House corresponding to Justice Miller's discussion of assembly, petition, and habeas corpus, see id. at 152 (citing Slaughter-House, 83 U.S. (16 Wall.) at 79); Newsom, supra note 12, at 710, and to Justice Bradley's more extensive discussion of the Bill of Rights, see Spies, 123 U.S. at 152 (citing Slaughter-House, 83 U.S. (16 Wall.) at 118 (Bradley, J., dissenting)); Newsom, supra note 12, at 710-11. "Thus, ... Tucker seemed to recognize ... that, while they did not agree about everything, the majority and dissenting Justices in Slaughter-House did agree that the Privileges or Immunities Clause incorporated core Bill of Rights freedoms." Newsom, supra note 12, at 711 (emphasis added).

185 Spies, 123 U.S. at 150.

186 Id.

187 Slaughter-House, 83 U.S. (16 Wall.) at 79; see also Newsom, supra note 12, at 709.

188 Spies, 123 U.S. at 166; see also Barron v. Baltimore, 32 U.S. (7 Pet.) 243 (1833); supra Part II.C (discussing Presser); Wildenthal, Lost Compromise, supra note 9, at Part II.A (discussing Twitchell), Part III.B (discussing Edwards and Walker), Part III.C (discussing Cruikshank), and Part IV (discussing Davidson).

189 See Spies, 123 U.S. at 167-82.

190 Id. at 182. For a contemporary argument taking a far narrower view of the Fourteenth Amendment than Tucker did, and castigating the Court for bothering as much as it did with the Haymarket case, see William H. Dunbar, The Anarchists' Case Before the Supreme Court of the United States, 1 HARV. L. REV. 307 (1888). 
with a pro-civil-rights Unionist like Butler. Both Southern Democrats and Reconstructionist Republicans, by the early 1870 s, seem to have accepted as common ground the incorporationist reading of both Slaughter-House and the Fourteenth Amendment. 191

But did Tucker's argument in Spies merely reflect the needs of his clients rather than his own views? That would seem unlikely based on his own comment, quoted above, that he took the case not to defend the anarchists but to "defend the Constitution." And why, indeed, would such a prominent and respected statesman and scholar choose to take such a high-profile and controversial case if he did not feel a genuine philosophical commitment to the argument?

Contrary evidence, however, is provided by Tucker's magisterial two-volume treatise on the Constitution, posthumously edited and published in 1899 by his son, Henry St. George Tucker, who also succeeded him in Congress and on the law faculty of Washington and Lee University. ${ }^{192}$ Tucker's treatise discussed the Fourteenth Amendment Privileges and Immunities Clause in two passages. The first, despite the teasing promise of Tucker's own rhetorical question- " [W] $]$ hat are the privileges or immunities of citizens of the United States as to the abridgment of which no State shall make or enforce any law?"193_never focused on the incorporation issue. He did quote Justice Miller's Slaughter-House formulation that they were "those which owe their existence to the Federal government, its national character, its constitution or its laws,"'194 and cited a couple, such as the privileges to vote and practice law, that the Court had found not protected. ${ }^{195}$ The second passage merely cited Walker-and Spies itself-for the proposition that

any denial of a right in a State court, which by any one of the ten amendments [of the Bill of Rights] is forbidden, is not unconstitutional, for those amendments are limits upon Federal power only, and the State court may do, contrary to the terms of those amendments, what the Federal court is forbidden to do. ${ }^{196}$

Perhaps Tucker, with a decade's hindsight, read Spies, in conjunction with the Court's anti-incorporation decisions before and since, as foreclosing the issue.

191 See Wildenthal, Lost Compromise, supra note 9, at Parts II.A and III.A.1.

192 See Henry St. George Tucker, Preface to 1 JOHN RANDOLPH TUCKER, THE CONSTITUTION OF THE UNITED STATES: A CRITCAL DISCUSSION OF ITS GENESIS, DEVELOPMENT, AND INTERPRETATION v-viii (Henry St. George Tucker ed., 1899); supra note 159.

1931 TUCKER, supra note $192, \S 174$, at 344.

194 Id. at 345 (quoting Slaughter-House, 83 U.S. (16 Wall.) at 79).

195 See id. (citing Minor v. Happersett, 88 U.S. (21 Wall.) 162 (1875), and Bradwell v. Illinois, 83 U.S. (16 Wall.) 130 (1873)).

1962 id. $\$ 389$, at 854; see also id. at 852-54. 
Tucker does not seem to have been one to bow to precedent for its own sake, ${ }^{197}$ so his own views may have shifted by the time of his death. In the final analysis, that does not matter much. As with Justice Miller's 1873 opinion in Slaughter-House, of ultimate importance is not what personal conclusion Tucker arrived at in the end, but the fact that his 1887 argument reflected a reasoned and relatively contemporary understanding that Slaughter-House may indeed be read in an incorporationist light. 198

While Tucker's argument might seem surprising and counterintuitive under the orthodox view of Slaughter-House and the early incorporation debate that has generally prevailed up to now, it is utterly unsurprising given the understanding of Slaughter-House urged in this author's previous article and reflected in the congressional debates of the early 1870 s. After all, Tucker was first elected to Congress in 1874, just after the incorporationist consensus on the Fourteenth Amendment and Slaughter-House seems to have reached its zenith, as advocated by Tucker's allies among states'-rights Southern Democrats. ${ }^{199}$ Butler was first elected to Congress in 1866, and served throughout that critical period in the early 1870 s. ${ }^{200}$ Their "odd bedfellows" collaboration in Spies was not so odd after all. It was an intriguing and highly symbolic revival of the lost compromise of SlaughterHouse.

\section{THE 1890s}

What are the privileges and immunities of citizens of the United States... ?... [A]fter much reflection I think the definition given at one time before this court by a distinguished advocate-Mr. John Randolph Tucker, of Virginia-is correct, that [they] are such as have their recognition in or guaranty from the Constitution of the United States. ${ }^{201}$

\section{See 1 id. at vii-viii:}

Th[is] book is an expression of the views of the author, not merely his intellectual opinions, but his deep convictions, in the consistent exercise of which he lived and in the faith of which he died; and neither the dissent of friendship, nor the storm of popular indignation, nor yet the hope of political preferment, ever shook his unswerving devotion to them. He religiously believed that the maintenance of these principles was necessary to the stability and preservation of the Union and the happiness and prosperity of the people, and that their rejection would as certainly result in tyranny, despotism and ultimate dissolution.

198 See Wildenthal, Lost Compromise, supra note 9, at Part IV (discussing the puzzle posed by the views of Miller and other Justices during the 1870s).

199 See id. at Part III.A.1; supra note 159.

200 See supra note 168.

201 O’Neil v. Vermont, 144 U.S. 323, 361 (1892) (Field, J., dissenting). 


\section{A. The Crossroads of O'Neil}

In $O^{\prime}$ Neil v. Vermont, ${ }^{202}$ the Supreme Court finally arrived at its most decisive nineteenth-century confrontation with the issue of incorporation. The Eighth Amendment immunity from cruel and unusual punishments was the bone of contention on this occasion. ${ }^{203}$ Incorporation lost, five to three. ${ }^{204}$

O'Neil was a crossroads in several ways. Bradley, the first Justice to unambiguously embrace total incorporation, ${ }^{205}$ died in office on January 22, 1892, just two days after the case was orally argued and less than three months before it was decided on April 4, 1892.206 The poignancy of that timing is somewhat diminished by the fact, as we have seen, that Bradley had apparently already abandoned his support for incorporation. And even if he had not, his vote would not have made the difference anyway.

If, however, Justice Woods had also survived on the Court until $O$ 'Neil was decided, when he would have been only sixty-seven ${ }^{207}$-and if he and Justice Bradley had both remained loyal to the incorporation theory they corresponded about and championed in the early $1870 \mathrm{~s}^{208}$-American constitutional history might have been very different. As discussed below, Justice Field, in the evening of his career at age seventy-five, ${ }^{209}$ finally resolved the mystery of his views by squarely embracing incorporation. Agreeing with Field on that point were Justice Harlan and Field's nephew, Justice David J. Brewer, appointed two years earlier. 210 During the seventy-four years between Slaughter-House and Adamson, O'Neil thus represents the high-water mark for the incorporation theory on the Court.

John O'Neil, a New York wine and liquor merchant, was convicted before a justice of the peace of 457 separate offenses of selling intoxicating liquors to customers in Vermont, in violation of that state's prohibition law, although his business was perfectly legal in New York. Because he had a prior conviction under the liquor law, he was subject to a fine of $\$ 20$ on each count, or $\$ 9,612.96$ including court costs (a rather hefty total in those days), and one month's imprisonment at

202144 U.S. 323 (1892).

203 See U.S. CONST. amend. VIII ("Excessive bail shall not be required, nor excessive fines imposed, nor cruel and umusual punishments inflicted.").

204 Compare O'Neil, 144 U.S. at 331-32, with id. at 359-65 (Field, J., dissenting), and id. at 370-71 (Harlan, J., joined by Brewer, J., dissenting).

205 See supra note 92.

206 O'Neil, 144 U.S. at 323; OXFORD SUPREME COURT, supra note 37, at 967.

207 See OXFORD SUPREME COURT, supra note 37, at 938. In fact, Woods died in office in 1887 at age sixty-two. See id. at $938,968$.

208 See supra note 92.

209 See OXFORD SUPREME COURT, supra note 37, at 289.

210 Id. at 89. 
hard labor. In addition, if the fine were not fully paid by expiration of the onemonth prison term, he was subject to three days additional imprisonment for each dollar of the fine-that is, 28,836 days, or about seventy-nine years. After appeal to county court and jury trial, this was reduced to 307 distinct offenses, fine and costs of $\$ 6,638.72$, and imprisonment (failing payment) for 19,914 days, or more than fifty-four years. ${ }^{211}$ This was, in the words of Justice Field's flabbergasted dissent, a "punishment ... exceeding in severity, considering the offences of which the defendant was convicted, anything which I have been able to find in the records of our courts for the present century."212

In O'Neil, however, as in Walker and Cruikshank, the incorporation issue was not raised before the U.S. Supreme Court. ${ }^{213}$ O'Neil did argue unsuccessfully before the Vermont Supreme Court that his sentence violated "[t]he constitutional inhibition of cruel and unusual punishments, or excessive fines or bail,"214 though it was unclear whether the issue was invoked or resolved under the state or federal constitutions or both. ${ }^{215}$ But no such claim was raised before the U.S. Supreme Court. The primary issue was whether Vermont's prosecution of O'Neil amounted to a regulation of interstate commerce violating the Commerce Clause. ${ }^{216}$ The

211 See O'Neil, 144 U.S. at 325-27, 330-31; id. at 337-39 (Field, J., dissenting); see also State v. Four Jugs of Intoxicating Liquor, 2 A. 586 (Vt. 1886), writ of error dismissed for want ofjurisdiction sub nom. O’Neil v. Vermont, 144 U.S. 323 (1892).

212 O'Neil, 144 U.S. at 338 (Field, J., dissenting).

Had [O'Neil] been found guilty of burglary or highway robbery, he would have received less punishment... It was six times as great as any court in Vermont could have imposed for manslaughter, forgery or perjury. It was one which, in its severity, considering the offences of which he was convicted, may justly be termed both unusual and cruel.

Id. at 339.

213 See Wildenthal, Lost Compromise, supra note 9, at Parts III.B-C (discussing Walker and Cruikshank).

214 Four Jugs, 2 A. at 593; see also O'Neil, 144 U.S. at 331.

215 The Vermont Supreme Court did not clarify the issue, holding merely that O'Neil's punishment

cannot be said to be excessive or oppressive. If he has subjected himself to a severe penalty, it is simply because he has committed a great many of such offenses.... If the penalty were unreasonably severe for a single offense, the constitutional question might be urged, but here the unreasonableness is only in the number of offenses the respondent has committed.

Four Jugs, 2 A. at 593; see also O'Neil, 144 U.S. at 331-32.

216 See U.S. CoNST. art. I, § 8, cl. 3; O'Neil, 144 U.S. at 334-36; id. at 344-59 (Field, J., dissenting); id. at 367-70 (Harlan, J., joined by Brewer, J., dissenting); Brief for Plaintiff in Error [i.e., O'Neil, the defendant at trial] at 6-20, O'Neil v. Vermont, 144 U.S. 323 (1892) [hereinafter O'Neil Defendant's Brief]; Brief for Defendant in Error [Vermont] at 2-10 (filed by Walter C. Dunton and P. Redfield Kendall), O'Neil v. Vermont, 144 U.S. 323 (1892); Brief for Defendant 
majority, in an opinion by Justice Samuel Blatchford, joined by Chief Justice Melville W. Fuller and Justices Horace Gray, Lucius Q.C. Lamar, and Henry B. Brown, stated, quite properly, that it would "forbear the consideration of th[e] [cruel and unusual punishment] question, because ... it is not assigned as error, nor even suggested in [O'Neil's] brief ...."217

Unfortunately, the Court promptly yielded to the temptation it had just sworn to "forbear." It stated that, "as a Federal question, it has always been ruled that the 8th Amendment ... does not apply to the States," citing a pre-1868 case in the Barron line. ${ }^{218}$ While technically a correct statement of law as to the Eighth Amendment standing alone, this rather unsatisfactorily ignored the existence of the Fourteenth Amendment. The dissenters, for their part, effectively conceded that the question had not been properly raised before the Court. ${ }^{219}$ But they proceeded to

in Error [Vermont] at 12-36 (filed by P. Redfield Kendall and George F. Edmunds), O'Neil v. Vermont, 144 U.S. 323 (1892). The majority and the dissenters disagreed on whether the Commerce Clause issue had been properly raised or addressed in the courts below and therefore on whether it was even properly before the Court. Compare id. at 335-37 (opinion of the Court) (holding that it was not, and therefore dismissing writ of error for want of jurisdiction), with id. at 349-53 (Field, J., dissenting) (arguing that it was), and id. at 367-69 (Harlan, J., joined by Brewer, J., dissenting) (same). Justices Field, Harlan, and Brewer, who agreed with each other that the Commerce Clause issue was properly before the Court, disagreed on how to resolve that issue on the merits. Compare id. at 353-59 (Field, J., dissenting) (arguing that Vermont had violated Commerce Clause), with id. at 369-70 (Harlan, J., joined by Brewer, J., dissenting) (arguing it had not). The depth of feeling the case aroused for Justice Field was reflected in a bizarre dispute he engaged in with the court reporter concerning the accuracy of the Reporter's headnote with regard to the majority's holding that the Commerce Clause issue was not properly preserved. See Alan F. Westin, Stephen J. Field and the Headnote to O'Neil v. Vermont: A Snapshot of the Fuller Court at Work, 67 YALEL.J. 363 (1958).

217 O'Neil, 144 U.S. at 331. See generally O'Neil Defendant's Brief, supra note 216. The Court added that, "so far as it is a question arising under the constitution of Vermont, it is not within our province." $O$ 'Neil, 144 U.S. at 331-32.

218 O'Neil, 144 U.S. at 332 (citing Pervear v. Massachusetts, 72 U.S. (5 Wall.) 475 (1867)); see also Barron v. Baltimore, 32 U.S. (7 Pet.) 243 (1833) (holding that the Takings Clause of the Fifth Amendment is intended solely as a limitation on the federal government and is not applicable to the states).

219 See O'Neil, 144 U.S. at 359-60 (Field, J., dissenting); id. at 370 (Harlan, J., dissenting). Justice Field argued that, jurisdiction over the case having been established, the Court could "look into the whole record," and "if it appears from the proceedings taken and the rulings made in the court below, on questions brought to its notice, that the rights of the accused, affecting his liberty or his life, have been invaded, this court may exercise its jurisdiction for the correction of the errors committed." Id. at 359. Citing the Court's discretionary authority, under goveming statutes and rules, to address "plain errors" not expressly raised, Field said, "I do not think we should be astute to avoid jurisdiction in a case affecting the liberty of the citizen." Id. at 360; see also id. at 370 (Harlan, J., dissenting) ("[]t is competent for this court to consider [the question], because we have jurisdiction of the case upon the grounds already stated."). 
address it anyway, thus indulging in the type of judicial activism seen previously on the other side in cases like Walker and Cruikshank. ${ }^{220}$ Such activism by the incorporationists was certainly more understandable, since-as the majority's justquoted dictum suggests-every passing year was fixing more firmly in precedential concrete the erroneous and improperly activist repudiation of incorporation in those very prior cases. The time had come to take a stand.

Justices Field and Harlan articulated the straightforward logic of textual incorporation in their O'Neil dissents. That much has been addressed by earlier scholarship.221 What has not been appreciated is how they drew upon the incorporationist language and logic of Justice Miller's Slaughter-House opinion. The connection is especially obvious when viewed in light of the other evidence set forth in this article and in light of the incorporationist reading of Slaughter-House set forth in this article's predecessor. 222

Justice Field began his analysis by conceding the established doctrine that the Eighth Amendment's prohibition of cruel and unusual punishments, like all Bill of Rights guarantees, did not itself apply to the states. "Such was undoubtedly the case previous to the Fourteenth Amendment, and such must be its limitation now, unless [it] is one of the privileges or immunities of citizens of the United States ...."223 Field then confronted his old nemesis, Slaughter-House, and, in what must have been a difficult reconciliation, he conceded, in effect, that the scope of Justice Miller's opinion was not so "vain and idle" as he had once contended.224 The Slaughter-House majority, Field noted, had held that the Amendment protected only

privileges or immunities of citizens of the United States as distinguished from privileges and immunities of citizens of the States. Assuming such to be the case, the question arises: What are the privileges and immunities of citizens of the United States which are thus protected? These terms are not idle words to be treated as meaningless, and the inhibition of their abridgment as ineffectual for any purpose, as some would seem to think. They are of momentous import, and the inhibition is a great guaranty to the citizens of the United States of those privileges and immunities against any possible state invasion. It may be difficult to define the terms so as to cover all [such] privileges and immunities ... but after much reflection I think the definition given at one time before this court by a distinguished advocate-Mr. John Randolph Tucker, of Virginia-is

220 See Wildenthal, Lost Compromise, supra note 9, at Parts III.B-C.

221 See, e.g., Morrison, supra note 26, at 150-51.

222 See Wildenthal, Lost Compromise, supra note 9, at Part II.

223 O'Neil, 144 U.S. at 360 (Field, J, dissenting).

224 See Slaughter-House, 83 U.S. (16 Wall.) at 96 (Field, J., dissenting); Wildenthal, Lost Compromise, supra note 9, at Part II.C. 
correct, that the privileges and immunities of citizens of the United States are such as have their recognition in or guaranty from the Constitution of the United States. ${ }^{225}$

Justice Field thus embraced, perhaps reluctantly, Tucker's vision of textual incorporation, which in turn, as we have seen, was based on Justice Miller's analysis and reflected the incorporationist compromise of Slaughter-House. ${ }^{226}$ Field continued by noting that, as modern scholars have confirmed and as he doubtless knew firsthand, "[ [] his definition is supported by reference to the history of the first ten Amendments to the Constitution, and of the Amendments which followed the late Civil War."227 As Field summarized:

While ... the [first] ten Amendments, as limitations on power, ... are applicable only to the Federal government and not to the States, yet, so far as they declare or recognize the rights of persons, they are rights belonging to them as citizens of the United States under the Constitution; and the Fourteenth Amendment, as to all such rights, places a limit upon state power by ordaining that no State shall make or enforce any law which shall abridge them. If I am right in this view, then every citizen of the United States is protected from punishments which are cruel and unusual. It is an immunity which belongs to him, against both state and Federal action. 228

Justices Harlan and Brewer declined to join Justice Field's dissent, but only (it appears) because they disagreed with his views on the Commerce Clause issue.229 In a separate dissent joined by Brewer, Harlan stated:

I fully concur with Mr. Justice Field, that since the adoption of the Fourteenth Amendment, no one of the fundamental rights of life, liberty or property, recognized and guaranteed by the Constitution of the United States, can be denied or abridged by a State.... These rights are, principally, enumerated in the earlier Amendments of the Constitution. ${ }^{230}$

225 O'Neil, 144 U.S. at 361 (Field, J., dissenting) (citing Spies, 123 U.S. at 150).

${ }^{226}$ See supra Part II.D. See generally Wildenthal, Lost Compromise, supra note 9.

227 O'Neil, 144 U.S. at 361 (Field, J., dissenting).

${ }^{228}$ Id. at 363 (Field, J., dissenting).

${ }^{229}$ See supra note 216; Westin, supra note 216, at 375.

230 O'Neil, 144 U.S. at 370 (Harlan, J., dissenting). The rights are only "principally" enumerated in the Bill of Rights because, of course, several are scattered throughout the original Constitution. See infra Part V and note 387. 
Brewer, regrettably, turned out not to be a steadfast adherent of incorporation, as perhaps foreshadowed by the slight ambiguity with which he joined Harlan's $O$ 'Neil dissent. ${ }^{231}$ And while the O'Neil dissents provide additional support for the incorporationist reading of Slaughter-House, they also underscore that any such compromise consensus was fading badly almost twenty years later.

Professor Morrison was quite unimpressed by $\mathrm{O}^{\prime} \mathrm{Neil}$ :

Here then, in 1892, we get the first intimation from any Justice... that the Fourteenth Amendment might be considered to incorporate the Bill of Rights. In view of the long line of cases beginning in 1875 in which the question could have been raised ... the conclusion is irresistible that it was not generally supposed that the Amendment incorporated the Bill of Rights .... It is obvious that the views expressed by ... [the] dissenting opinions in O'Neil $v$. Vermont were in the nature of an afterthought. ${ }^{232}$

We have already seen how thoroughly wrong that is. But there is no question that as the 1890s dawned, the anti-incorporationists had the upper hand.

In several other cases decided in the early 1890 s, the Court touched briefly on the issue. For example, in Eilenbecker v. District Court of Plymouth County, ${ }^{233}$ the Court, in a unanimous opinion by Justice Miller, ${ }^{234}$ upheld punishment for contempt of court without benefit of jury trial or other incidents of ordinary criminal prosecution. The Court recited in passing the rule that the first eight amendments,

231 See id. at 371 (Harlan, J., dissenting) ("Mr. Justice Brewer authorizes me to say that in the main he concurs with the views expressed in this opinion."); infra Part III.B (discussing Brewer's anti-incorporationist opinion in Brown v. New Jersey, 175 U.S. 172 (1899)). Brewer later joined silently in the anti-incorporationist majority opinions in Maxwell v. Dow, 176 U.S. 581 (1900), and Twining v. New Jersey, 211 U.S. 78 (1908), discussed infra Part IV. On the other hand, in Chicago, Burlington \& Quincy R.R. Co. v. Chicago, 166 U.S. 226 (1897), Brewer not only agreed with the majority's incorporation of the Takings Clause, he dissented alone from the Court's finding that no further compensation was due in that case. Id. at 258-63 (Brewer, J., dissenting); see also infra Part III.B. Brewer was generally known as a conservative defender of laissez-faire economic liberties (like his uncle, Field), with a mixed record on civil rights. For example, he wrote the Court's opinion in Berea College v. Kentucky, 211 U.S. 45 (1908), from which Harlan dissented, see supra note 50, but he did not participate in Plessy v. Ferguson, 163 U.S. 537, 564 (1896), and dissented alongside Harlan in Giles v. Harris, 189 U.S. 475, 488-93 (1903) (Brewer, J., dissenting), see supra note 51 . He also had a more progressive record than Harlan or the Court as a whole in cases involving Asian immigrants. See supra note 58 (discussing Harlan's dismal record in Chinese cases); OXFORD SUPREME COURT, supra note 37, at 89-90; J. Gordon Hylton, The Judge Who Abstained in Plessy v. Ferguson: Justice David Brewer and the Problem of Race, 61 Miss. L.J. 315 (1991).

232 Morrison, supra note 26, at 151-52.

233 134 U.S. 31 (1890).

${ }^{234} \mathrm{He}$ would die in office later that year. OXFORD SUPREME COURT, supra note 37, at 967. 
of their own force, restrict only the federal government. ${ }^{235}$ But it relied on the special character of criminal contempt proceedings, not on any broad repudiation of incorporation, to find no violation of the Fourteenth Amendment. ${ }^{236}$

In Miller $v$. Texas, ${ }^{237}$ the Court rejected a convicted murderer's challenge to a Texas law restricting the carrying of weapons and authorizing the warrantless arrest of persons violating the law. The Court's brief, unanimous opinion by Justice Brown stated that it had "examined the record in vain ... to find where the defendant was denied the benefit"238 of the Second or Fourth Amendment rights to bear arms and be free of unreasonable searches or seizures. Again, it noted, these did not apply of their own force to the states. ${ }^{239}$ Furthermore, the Court held, "if the Fourteenth Amendment limited the power of the States as to such rights ... it was fatal to this claim that it was not set up in the trial court."240

The Court rejected appeals by New York death row inmates, alleging cruel and unusual punishment in violation of the Fourteenth Amendment, in two other cases: In re Kemmler ${ }^{241}$ and McElvaine v. Brush. ${ }^{242}$ In each case, in unanimous opinions by Chief Justice Fuller, the Court acknowledged the argument that the Eighth Amendment applied to the states via the Fourteenth. ${ }^{243}$ In response, Kemmler cited the narrow readings of the Privileges and Immunities Clause in Cruikshank and the Due Process Clause in Hurtado. ${ }^{244}$ McElvaine simply cited Kemmler. ${ }^{245}$ A review of the briefs reveals that the prisoner's attorney in Kemmler tried to revive Tucker's incorporation argument in Spies. ${ }^{246}$ The prisoner's attorney in McElvaine invoked

235 Eilenbecker, 134 U.S. at 33-35 (citing both pre- and post-1868 cases).

${ }^{236} \mathrm{Id}$. at 35-39. It was not until much later that the Court applied the right of jury trial to some criminal contempt proceedings, at least those involving more than "petty" punishment, at either the state or federal level. See, e.g., Bloom v. Illinois, 391 U.S. 194 (1968); United States v. Barnett, 376 U.S. 681, 694 n.12 (1964). Cf. Newsom, supra note 13, at 721-23 (discussing Eilenbecker).

237153 U.S. 535 (1894).

$238 \mathrm{Id}$. at 538.

${ }^{239} I d$. (citing, e.g., Barron, Cruikshank, and Spies).

240 Id. (emphasis added).

241136 U.S. 436 (1890) (challenging electrocution as method of execution).

242142 U.S. 155 (1891) (challenging solitary confinement prior to execution, under same New York statute generally upheld in Kemmler).

243 Kemmler, 136 U.S. at 445-46; McElvaine, 142 U.S. at 158.

244 Kemmler, 136 U.S. at 448.

245 McElvaine, 142 U.S. at 158.

246 See supra Part II.D. Compare Brief for Plaintiff in Error [i.e., Kemmler, the defendant at trial] at 7-9, In re Kemmler, 136 U.S. 436 (1890) [hereinafter Kemmler Defendant's Brief], with Brief for Agent and Warden at 14-21, In re Kemmler, 136 U.S. 436 (1890) [hereinafter Kemmler State's Brief]. 
the Eighth Amendment but neglected to mention the Fourteenth or any theory of incorporation. ${ }^{247}$

The dominant rationale of both Kemmler and McElvaine was simply that the challenged methods of punishment were not (in the Court's view) cruel and unusual, and that issue was also the dominant focus of the briefs. ${ }^{248}$ Professor Morrison made much of Kemmler and McElvaine and the fact that Justices Field, Harlan, and Brewer concurred silently in both decisions. This, he argued, caught them in a peculiar "change of heart" when they later dissented in O'Neil. 249 But the opinions in Kemmler and McElvaine were handed down only three and fourteen days after oral argument, respectively, ${ }^{250}$ and it seems hardly surprising that the O'Neil dissenters, who apparently agreed with the result and the dominant rationale, did not bother to churn out separate opinions delving into incorporation. They did so soon enough in O'Neil, when first confronted by a punishment they felt did implicate the Eighth and Fourteenth Amendments. Morrison's treatment of Kemmler and McElvaine provides still more evidence of his tendentiously skewed approach to this entire line of case law.

\section{B. The Curious Exception of Chicago B\&Q}

Five years after $O^{\prime} N e i l$, in Chicago, Burlington \& Quincy Railroad Co. $v$. Chicago (Chicago $B \& Q$ ), ${ }^{251}$ the Court faced the question whether the Fourteenth Amendment guarantees the right to just compensation for takings of private property. The railroad objected to the city's appropriation, for compensation fixed

247 See Brief for Appellant at 22-23, McElvaine v. Brush, 142 U.S. 155 (1891) [hereinafter McElvaine Appellant's Brief]. This is easily the most bizarre brief I have ever read (and as a former federal and state appellate court law clerk, I've seen quite a few clunkers). The attomey, who seems to have been somewhat daft, expounded at remarkable length and in irrelevant and gruesome detail on methods of execution in the Europe of antiquity, id. at 11-20, and (typical of editorial digressions throughout) commented at one point that "[t]he Constitution of the United States, be it said with all reverence and Christian piety, is an inspiration of the Deity, as were the Books of Moses and the Acts of the Apostles," id. at 22. The state, responding cautiously at one point that "it is not entirely clear what was the exact point intended to be raised" by the underlying habeas corpus petition, Brief for Agent and Warden at 14, McElvaine v. Brush, 142 U.S. 155 (1891) [hereinafter McElvaine State's Brief], relied mainly on Kemmler as authority for rejecting any Fourteenth Amendment challenge, $i d$. at 12-13, 19.

248 See Kemmler, 136 U.S. at 443-44, 446-49; McElvaine, 142 U.S. at 158-60; Kemmler Defendant's Brief, supra note 246, at 10-28; Kemmler State's Brief, supra note 246, at 21-24; McElvaine Appellant's Brief, supra note 247, at 5-21, 23-34; McElvaine State's Brief, supra note 247 , at 8-16.

249 See Morrison, supra note 26, at 148-50.

250 Kemmler, 136 U.S. at 436; McElvaine, 142 U.S. at 155.

251 166 U.S. 226 (1897). 
at one dollar, of a public right-of-way for a road crossing. ${ }^{252}$ As in Hurtado, the Due Process Clause rather than the Privileges and Immunities Clause was invoked as the vehicle of protection. ${ }^{253}$ The railroad may have done so in part because of the long-established (though erroneous) rule that corporations are not "citizens" protected by the Article IV Privileges and Immunities Clause. ${ }^{254}$ In any event, in striking contrast with all the other post-Slaughter-House cases we have seen, the Court agreed unanimously with the railroad that the right of just compensation was, in effect, incorporated in the Fourteenth Amendment ${ }^{255}$ _though it also held, over Justice Brewer's solitary dissent, that no further compensation was due in this case. ${ }^{256}$

What can account for this dramatic departure? Because the Fifth Amendment guarantees both due process and just compensation, ${ }^{257}$ the logic (if any) of Hurtado's argument from superfluity plainly dictated rejection of incorporation in Chicago $B \& Q{ }^{258}$ Indeed, the Court had forecast exactly that conclusion, for exactly that reason, in dicta nineteen years earlier. ${ }^{259}$ The superfluity argument actually has more force in the case of just compensation than with grand jury indictment, since

252 Id. at 230 .

253 Id. at 232-33; Brief for Plaintiff in Error at 34-50, Chicago, Burlington \& Quincy R.R. Co. v. Chicago, 166 U.S. 226 (1897) (No. 129) [hereinafter Chicago $B \& Q$ Railroad's Brief]. The city did not dispute the railroad's argument that due process required just compensation (state law already required just compensation), Chicago $B \& Q, 166$ U.S. at 228-30; Brief for Defendant in Error at 4-12, Chicago, Burlington \& Quincy R.R. Co. v. Chicago, 166 U.S. 226 (1897) (No. 129) [hereinafter Chicago $B \& Q$ City's Brief], but the city did dispute whether any further compensation was required in this case, Chicago $B \& Q$ City's Brief, supra, at 30-43.

${ }^{254}$ U.S. CONST. art. IV, § 2, cl. 1; Paul v. Virginia, 75 U.S. (8 Wall.) 168, 180-82 (1869). The Fourteenth Amendment clause was derived from the Article IV clause, and there would not seem to be any reason to treat corporations as "citizens" under one but not the other. Modern scholarship has demonstrated that this limitation is unwarranted and anachronistic, and should not apply to either clause, but it doubtless cemented the railroad's decision to rely on the Due Process Clause, which had by then been found to protect corporations as "persons." See Wildenthal, Lost Compromise, supra note 9, at 1086 n.132.

255 Chicago B\&Q, 166 U.S. at 233-41; id. at 258-59 (Brewer, J., dissenting) (agreeing with majority on this point). Chief Justice Fuller did not participate in Chicago $B \& Q$, id. at 263, but he soon indicated his agreement with its holding on this point, by joining silently in Justice Harlan's opinion for the Court reaffirming it in Norwood v. Baker, 172 U.S. 269, 277 (1898).

256 Compare Chicago B\&Q, 166 U.S. at 241-58, with id. at 258-63 (Brewer, J., dissenting).

257 U.S. CONST. amend. V ("No person shall . . . be deprived of life, liberty, or property, without due process of law; nor shall private property be taken for public use, without just compensation.").

258 See Hurtado v. California, 110 U.S. 516, 534-35 (1884); supra Part II.B.

259 See Davidson v. New Orleans, 96 U.S. 97, 105 (1878); supra Part II.B; Wildenthal, Lost Compromise, supra note 9, at Part IV. 
just compensation is arguably not a procedural guarantee at all, but rather a substantive right, and thus not properly within the concept of due process.

The obvious explanation for Chicago $B \& Q$ is the Court's well-known and overriding concern during this era with economic liberty and the defense of business and property interests. Mere logic and consistency were no match. On the very same day the Court decided Chicago $B \& Q$, it squarely endorsed the doctrine of economic substantive due process for the first time, in Allgeyer v. Louisiana. ${ }^{260}$ Justice Field, who retired later that year at age eighty-one, ${ }^{261}$ must have been very pleased at this double-barreled vindication (though only partial and implicit with regard to incorporation) of his dissenting views in both Slaughter-House and O'Neil.

It was most fitting that Justice Harlan - the lone dissenter in Hurtado and the great champion of incorporation - wrote the opinion of the Court in Chicago $B \& Q .{ }^{262}$ He would soon have occasion to chide his brethren for their inconsistency in failing to support incorporation of other Bill of Rights guarantees, noting tartly that "it would seem that the protection of private property is of more consequence than the protection of the life and liberty of the citizen."263 In Chicago $B \& Q$, however, he was obviously bound by the need to reflect his colleagues' views and conform to precedent. Professor Morrison ignored this factor, most unfairly accusing Harlan of "pass[ing] over another opportunity to assert the doctrine that the Fourteenth Amendment incorporated the Bill of Rights." 264 This was, to say the least, an odd way to characterize Harlan's role in the first case to hold that the Fourteenth Amendment did indeed protect a privilege specified in the Bill of Rights. ${ }^{265}$

The result of these tensions was a curious text. On the one hand, Justice Harlan's historical analysis of due process in $C$ icago $B \& Q$ reads, not surprisingly, much like that of his Hurtado dissent, and was fundamentally inconsistent with the reasoning and approach of the Hurtado majority. ${ }^{266}$ On the other hand, the opinion

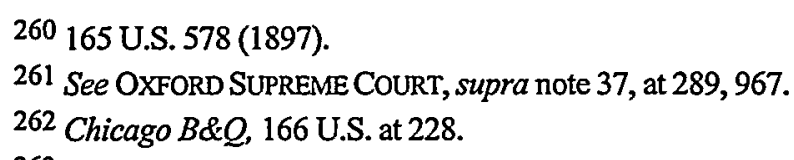

261 See OXFORD SUPREME COURT, supra note 37, at 289, 967.

262 Chicago $B \& Q, 166$ U.S. at 228.

263 Maxwell v. Dow, 176 U.S. 581, 614 (1900) (Harlan, J., dissenting); see also infra Part IV. As Professor Curtis has noted, "Harlan was prophetic. As the [Fourteenth] [A]mendment shrank as a protection of liberties explicitly written into the Bill of Rights, it grew as a protection of liberty of contract." CURTIS, NO STATE, supra note 12, at 195.

${ }^{264}$ Morrison, supra note 26, at 152.

265 Morrison also ignored the fact that the Privileges and Immunities Clause did not apply to the railroad (according to prevailing case law) because of its corporate status. See supra note 254.

266 Compare Chicago B\&Q, 166 U.S. at 235-41, with Hurtado, 110 U.S. at 539-58 (Harlan, J., dissenting). 
was amusingly coy about the fact that it was, in reality, incorporating the Takings Clause of the Fifth Amendment ${ }^{267}$ - to the point that the latter provision was treated like the proverbial elephant in the parlor, not even cited or mentioned. ${ }^{268}$ The superfluity issue that the Hurtado majority made so much of was also, like Hurtado itself, studiously ignored. 269

In retrospect, Chicago $B \& Q$ was the pioneering example of what would later become known as "selective incorporation." 270 But in historical context, it sheds more light on the pro-business ideology of that Court than on the theory of incorporation.

Despite Justice Brewer's alliance with Justices Harlan and Field in O'Neil, and his enthusiastic support for incorporating the Takings Clause in Chicago B\&Q, he soon abandoned the idea of total incorporation. He wrote the opinion of the Court in Brown v. New Jersey, rejecting a challenge to a state's procedure for peremptory

267 See, e.g., Phillips v. Wash. Legal Found., 524 U.S. 156, 163-64 (1998) (Chicago B\&Q "made [the Takings Clause] applicable to the States through the Fourteenth Amendment ....").

268 The closest Harlan came to hinting at the existence of a federal right to just compensation, separate from the general guarantee of due process, was to twice note that the Illinois Constitution contained both guarantees. Chicago $B \& Q, 166$ U.S. at 228, 233. This was in sharp contrast to his Hurtado dissent, which quite logically cited the explicit guarantee of grand jury indictment in the Fifth Amendment as evidence for the historical fundamentality of that right. Hurtado, 110 U.S. at 546 (Harlan, J., dissenting). The railroad was not shy about drawing attention to the Fifth Amendment Takings Clause, and even relied on it as a separate basis for relief in addition to the Fourteenth Amendment Due Process Clause-a point omitted by Harlan in his description of the railroad's "general contentions" on appeal. Chicago B\&Q, 166 U.S. at 232; Chicago $B \& Q$ Railroad's Brief, supra note 253, at 10. The railroad, in contrast to Harlan's rather elliptical approach, based its argument quite squarely on the logic of total and textual incorporation, reminiscent of Tucker's argument in Spies, and even hinted at reliance on the Privileges and Immunities Clause:

The first ten amendments ... recognized and secured to all citizens certain rights, privileges and immunities essential to their security. The Fifth Amendment, operating only as a limitation upon the powers of the general government, fell short of giving to the citizen ... full protection..., so far as state action was concemed. It imposed no prohibition or limitation upon the power and authority of the states.... The Fourteenth Amendment was adopted to remedy and correct this defect in the supreme organic law of the land... [A]s applied to the appropriation of private property for public uses, [it] was clearly intended to place the same limitation upon the power of the states which the Fifh Amendment had placed upon the authority of the Federal government.

Chicago B\&Q Railroad's Brief, supra note 253, at 46-47.

269 Professor Curtis aptly described this as the "elegantly simple method courts sometimes use when precedent seems to preclude the desired result." CURTIS, NO STATE, supra note 12, at 189.

270 See, e.g., Duncan v. Louisiana, 391 U.S. 145, 147-50 \& n.14 (1968); id. at 163-64, 171 (Black, J., joined by Douglas, J., concurring). 
jury challenges in criminal cases. ${ }^{271}$ The outcome would probably have been the same even if the Sixth Amendment right to jury trial had been found to apply, but Brewer asserted that the Bill of Rights did not apply to the states. ${ }^{272} \mathrm{He}$ offered a highly restrictive interpretation of the Fourteenth Amendment, quoting language in Missouri v. Lewis ${ }^{273}$ suggesting that states were free to abolish jury trial altogether. ${ }^{274} \mathrm{He}$ added that "[ $\left.\mathrm{t}\right] \mathrm{he}$ State is not tied down by any provision of the Federal Constitution to the practice and procedure which existed at the common law."275 Harlan concurred only in the result. 276

\section{THE DAWN OF A NEW CENTURYAND THE END OF AN AULD SANG:277 MAXWELL, PATTERSON, AND TWINING}

At the close of the late Civil War... the question arose whether provision should not be made by constitutional amendments to secure against attack by the States the rights, privileges, and immunities which, by the original Amendments, had been placed beyond the power of the United States or any Federal agency to impair or destroy... The privileges and immunities mentioned in the original Amendments, and universally regarded as our heritage of liberty from the common law, were thus secured [by the Fourteenth Amendment] to every citizen of the United States and placed beyond assault by any government, Federal or state.... ${ }^{278}$

The final decade of Justice Harlan's life and career on the Supreme Court saw the most definitive blows yet to the incorporation theory, blows from which it would not shakily recover until more than fifty years later. In Maxwell v. Dow, 279 a Utah defendant, Charles Maxwell, appealed from a robbery conviction rendered

271175 U.S. 172, 175-77 (1899).

272 Id. at 174.

273101 U.S. 22 (1880); see also Wildenthal, Lost Compromise, supra note 9, at Part IV.

274 Brown, 175 U.S. at 175 (quoting Lewis, 101 U.S. at 31).

275 Id.; see also id. at 174-75 (citing, e.g., Cruikshank and Hurtado).

${ }^{276} \mathrm{Id}$. at 177 . The decision was otherwise unanimous. Field, having retired in 1897 , died in 1899 before Brown was decided. See id. at 172; OXFORD SUPREME COURT, supra note 37, at 289.

277 See NIGEL TRANTER, THE STORY OF SCOTLAND 203 (1987) (noting that the Earl of Seafield, upon the dissolution of the Scottish Parliament in 1707 by the Treaty of Union with England, commented, "There's an end to an auld sang!'); id. at 195-204 (ch. 16, "The End of an Auld Sang").

${ }^{278}$ Twining v. New Jersey, 211 U.S. 78, 121-22 (1908) (Harlan, J., dissenting).

279176 U.S. 581 (1900). 
by a jury of eight rather than twelve. ${ }^{280}$ The Court, in an opinion by Justice Rufus W. Peckham speaking for all of his colleagues save Harlan, acknowledged "no doubt"281 that in federal court this would violate the Sixth Amendment right to criminal jury trial. ${ }^{282}$ And for the first time, a majority gave at least somewhat extended treatment to the issue whether that and other guarantees of the Bill of Rights also bind the states via either the Privileges and Immunities or Due Process Clauses of the Fourteenth Amendment. ${ }^{283}$ But Peckham concluded by rejecting Maxwell's claim, and his opinion was a disaster.

The Court recited Justice Miller's list of privileges and immunities in Slaughter-House -including, provocatively, the rights of peaceable assembly and habeas corpus 284 -but noted that the "right...claimed here, was not mentioned,"285 and therefore concluded, rather smugly, that "we may suppose it was...not covered by the amendment."286 This was hardly reasonable, since Miller had expressly noted the merely illustrative nature of his list. 287 The majority also made no attempt to explain why jury trial should be treated differently from peaceable assembly, which, as it had just noted, was "mentioned." At most, the Court succeeded in demonstrating that Slaughter-House had no specific bearing on the issue of jury trial, which, of course, it did not. Neither did Cruikshank. It was not essential to either of those decisions to reach any conclusion regarding incorporation of the Bill of Rights. ${ }^{288}$ Yet the Maxwell Court asserted, with absurd exaggeration, that "if all these rights are included in the phrase 'privileges and immunities' of citizens of the United States... then the sovereignty of the

$280 \mathrm{Id}$. at 583 . Maxwell also protested his prosecution by information rather than by grand jury indictment, claiming that Hurtado, which involved only the Due Process Clause, had not settled the issue whether that right was encompassed by the Privileges and Immunities Clause. The Court made short shrift of that argument, treating Hurtado as settling the issue for all purposes under the Fourteenth Amendment. Id. at 584-85.

281 Id. at 586.

282 U.S. CONST. amend. VI ("In all criminal prosecutions, the accused shall enjoy the right to...trial, by an impartial jury of the State and district wherein the crime shall have been committed, which district shall have been previously ascertained by law ....").

283 See Maxwell, 176 U.S. at 587-602 (analyzing issue under Privileges and Immunities Clause); id. at 602-05 (analyzing issue under Due Process Clause).

284 Id. at $590-91$.

285 Id. at 591 .

286 Id.

287 Slaughter-House, 83 U.S. (16 Wall.) at 79 ("ventur[ing] to suggest some" of the rights protected by the Privileges and Immunities Clause) (emphasis added); see also Tribe, Saenz, supra note 13, at 183-84 n.330; Wildenthal, Lost Compromise, supra note 9, at Part II.C.

288 See Wildenthal, Lost Compromise, supra note 9, at Parts II and III.C. 
state ... has been entirely destroyed, and the Slaughter-House [C]ases and... Cruikshank are all wrong, and should be overruled."289

Aside from such dodgy misuse of precedent, ${ }^{290}$ Justice Peckham offered the following rather mind-numbing example of formalistic hair-splitting:

In none [of the first eight amendments] are [the rights they guarantee] privileges or immunities granted and belonging to the individual as a citizen of the United States, but they are secured to all persons as against the Federal government, entirely irrespective of such citizenship. As the individual does not enjoy them as a privilege of citizenship of the United States, therefore, when the Fourteenth Amendment prohibits the abridgment by the States of those privileges or immunities which he enjoys as such citizen, it is not correct or reasonable to say that it covers and extends to certain rights which he does not enjoy by reason of his citizenship, but simply because those rights exist in favor of all individuals as against Federal governmental powers. ${ }^{291}$

The argument seems to be that since the Bill of Rights generally protects aliens who come within the jurisdiction of the United States, ${ }^{292}$ as well as American citizens, such rights are not an exclusive attribute of citizenship. This was lawyerly nonsense of the worst sort, as Professor Amar has amply demonstrated. ${ }^{293}$ One turns with relief to the refreshing common sense of Justice Black: "What more precious 'privilege' of American citizenship could there be than that privilege to

289 Maxwell, 176 U.S. at 593.

290 To be sure, as this article and its predecessor have discussed, there were by this time quite a few cases rejecting the idea of incorporation, and Justice Peckham, not surprisingly, made use of them. For example, he quoted verbatim almost the entire opinion of the Court in Walker $v$. Sauvinet, 92 U.S. 90 (1876), see Maxwell, 176 U.S. at 594-95, and he also quoted and discussed at great length Missouri v. Lewis, 101 U.S. 22 (1880), see Moxwell, 176 U.S. at 598-601. See Wildenthal, Lost Compromise, supra note 9, at Part III.B (discussing Walker) and Part IV (discussing Lewis).

291 Maxwell, 176 U.S. at 595-96.

292 One should use the word "generally" with caution, in view of the Court's recent, outrageous decision in Reno v. American-Arab Anti-Discrimination Committee, 525 U.S. 471 (1999) (upholding federal statute depriving courts of jurisdiction to entertain claims by permanent resident aliens that they were targeted for deportation because of political affiliations protected by First Amendment).

293 See AMAR, BLL OF RIGHTS, supra note 12, at 169-71, 362-63 nn.19-27; Amar, supra note 12, at 1222-23. Amar was responding to Professor Louis Henkin, who had earlier echoed this "technical objection" to incorporation. Cf. Louis Henkin, "Selective Incorporation" in the Fourteenth Amendment, 73 YALELJJ. 74, 78 n.16(1963); AMAR, BLL OF RIGHTS, supra note 12, at $362 \mathrm{n.19}$ (noting origins of argument in Maxwell). But cf. Douglas G. Smith, Reconstruction or Reaffirmation?: Review of "The Bill of Rights: Creation and Reconstruction," 8 GEO. MASON L. REV. 167, 187-88 (1999) (questioning Amar's resolution of the issue). 
claim the protections of our great Bill of Rights?"294 The fact that such rights are also enjoyed by foreigners visiting our shores would be a truly bizarre reason to allow the states to deny them even to American citizens. ${ }^{295}$ In any event, to the extent one relies on the original understanding, Professor Amar showed that those who proposed and adopted the Fourteenth Amendment in fact believed, rightly or wrongly, that only citizens could claim the protection of the Bill of Rights. ${ }^{296}$

${ }^{294}$ Duncan v. Louisiana, 391 U.S. 145, 166 (1968) (Black, J., joined by Douglas, J., concurring). As Justice Harlan noted in Maxwell:

In order to form a more perfect union, establish justice, insure domestic tranquillity, provide for the common defence, promote the general welfare, and secure the blessings of liberty to themselves and their posterity, the political community known as the People of the United States ordained and established the Constitution ...; and every member of that political community was a citizen of the United States. It was that community that adopted, in the mode prescribed by the Constitution, the first ten amendments; and what they had in view by so doing was to make it certain that the privileges and immunities therein specified... could never be impaired or destroyed by the National Government.

Maxwell, 176 U.S. at 608 (Harlan, J., dissenting). Or, as Maxwell himself succinctly argued: "If these rights, privileges, and immunities, did not pertain to the people as citizens of the United States, it is difficult to see in what relation they did belong to them." Brief for Plaintiff in Error [i.e., Maxwell, the defendant at trial] at 8, Maxwell v. Dow, 176 U.S. 581 (1900) [hereinafter Maxwell Defendant's Brief].

295 As Amar stated so well:

In ordinary, everyday language we often speak of the United States Constitution and Bill of Rights as declaring and defining rights of Americans as Americans. Surely our Constitution is not centrally about declaring, say, the rights of Germans qua Germans, or the Chinese qua Chinese .... Surely the fact that Americans may often extend many benefits of our Bill [of Rights] to, say, resident aliens-for reasons of prudence, principle, or both-does not alter the basic fact that these rights are paradigmatically rights of and for American citizens. Indeed, others may enjoy certain benefits only insofar as they interact with American citizens, typically because they either live on soil govemed by American citizens or do things with important effects on American citizens. Peripheral applications of the Bill [of Rights] should not obscure its core.

AMAR, BILL OF RIGHTS, supra note 12, at 170; see also Amar, supra note 12, at 1222.

296 See AMAR, BILL OF RIGHIS, supra note 12, at 170-71; Amar, supra note 12, at 1222-23. I happen to strongly disagree with that view of the protective scope of the Bill of Rights itself, but that issue need not be pursued here. On the other hand, the limitation of the Privileges and Immunities Clause's protection to citizens seems clearly dictated by its text. I agree with Amar, however, that this is not grounds for undue concern, because (1) aliens, like all "persons" within American jurisdiction, enjoy the protection of the Due Process Clause, which is properly read to incorporate all procedural guarantees of the Bill of Rights, see supra Part II.B, (2) they are also covered by the Equal Protection Clause, under which states must "justify any discrimination between citizens and aliens," and (3) "aliens may sometimes be able to present themselves as third party beneficiaries of citizen rights," e.g., an alien's right to speak may be protected as a corollary of the citizen's right to hear. See AMAR, BLL OF RIGHTS, supra note 12, at 364-65 n.42; Amar, supra note 12 , at $1226 \mathrm{n} .153$. I would add the preemption principle under which states are 
Equally deficient was the Court's treatment of the Fourteenth Amendment's legislative history. Faced with Maxwell's invocation of Senator Howard's famous and uncontradicted 1866 speech, 297 the majority casually dismissed it with the comment that "[w]hat speeches were made by other Senators and... Representatives ... is not stated ... nor ... what construction was given to it, if any, by other members of Congress."298 The majority referred to Howard's address merely as "the speech of one of the Senators of the United States, made in the Senate when the proposed Fourteenth Amendment was under consideration by that body ...."299 Yet Maxwell's brief had pointed out that Howard was not merely "one of the Senators" but rather was a member of the joint House-Senate committee that prepared and reported the Amendment, and was entrusted with formally presenting it to the Senate on the committee's behalf. ${ }^{300}$ Nor could his exhaustive and lengthy speech properly be dismissed as casual remarks uttered in the course of debate. 301

Eight years later, in Twining $v$. New Jersey, ${ }^{302}$ the Court, in an opinion by Justice William H. Moody, had clearly grown tired of the debate and relied mainly on the now-crushing weight of precedent. ${ }^{303}$ Twining excluded the Fifth Amendment privilege against self-incrimination from the scope of the Fourteenth Amendment. ${ }^{304}$ In a sense, of course, this was logically compelled by prior

generally prohibited from discriminating against aliens who have been legally admitted to the United States under federal law. See, e.g., Toll v. Moreno, 458 U.S. 1 (1982) (holding that a state university may not deny certain domiciled nonimmigrant aliens in-state tuition status on an equal basis with domiciled citizens).

297 See supra note 115.

298 Maxwell, 176 U.S. at 601.

299 Id.

300 Maxwell Defendant's Brief, supra note 294, at 9-10.

301 Id. at 10-12 (quoting speech at length). Maxwell pointed out that Howard's speech "sets out clearly and forcibly" the need for and purpose of the Amendment. Id. at 12.

302211 U.S. 78 (1908).

303 See supra text accompanying notes 2-7 (quoting majority opinion). Midway between Maxwell and Twining, Justice Peckham wrote the Court's opinion in West v. Louisiana, 194 U.S. 258, 261-67 (1904), holding that the Fourteenth Amendment did not incorporate the right of a criminal defendant "to be confronted with the witnesses against him." U.S. CONST. amend. VI. Justice Harlan alone dissented, without opinion. West, 194 U.S. at 267. Perhaps he was getting tired too.

304 See U.S. CONST. amend. V ("No person shall . . . be compelled in any criminal case to be a witness against himself...."). The facts of Twining, a state fraud prosecution, raised only the narrower issue whether, even assuming a privilege against self-incrimination, the trial judge erred by instructing the jury that it might draw unfavorable inferences from the failure of Albert Twining's codefendant, David Comell, to testify in response to a specific accusation made against him. The judge also pointed out to the jury Twining's failure to take the stand in his own defense, 
decisions, as Justice Harlan had repeatedly wamed, starting with his parade of horribles in Hurtado. ${ }^{305}$ Moody now saluted this foresight, noting that "Mr. Justice Harlan, in his dissent in each of these cases, pointed out that the inexorable logic of the reasoning of the court was to allow the states ... to compel any person to be a witness against himself." 306 One can only try to imagine Harlan's reaction upon reading the draft opinion.

"Is [the privilege against self-incrimination]," asked the Twining Court, "a fundamental principle of liberty and justice which inheres in the very idea of free government and is the inalienable right of a citizen of such a government?"307 Incredibly, it said no. ${ }^{308}$ Justice Moody commented very tellingly that this shield for the inviolable dignity of the human mind, so painfully won by the British in response to the infamous abuses of the Star Chamber, 309 "cannot be ranked with ... the inviolability of private property." 310 That was evidently enough for the majority to distinguish Twining from Chicago $B \& Q$. Justice Harlan protested in vain that compulsory self-incrimination, as the Court itself had suggested years before, 311 was "abhorrent to the instincts of Americans... and a weapon of despotic power which could not abide the pure atmosphere of political liberty and personal freedom...."312

Justice Harlan's lonely dissents in Maxwell and Twining have the eloquence of long and weary struggle. He asked in Maxwell, with straightforward logic any layperson could follow:

while discounting the significance of that. See Twining, 211 U.S. at 79-83, 90-91. Twining and Comell both appealed their convictions on this basis, and the Supreme Court found it unnecessary "to consider whether... there is any difference in the situation of the two defendants. It is assumed, in respect of each, that the jury were instructed that they might draw an unfavorable inference against him from his failure to testify...." Id. at 90 . The Court found it appropriate to first resolve whether the privilege applied to the states at all, thus avoiding any need to resolve its scope or application to the facts at bar. Id. at 91, 114. Cf. id. at 115-17 (Harlan, J., dissenting) (complaining at some length about majority's decision to address issues in that order).

305 See supra Part II.B.

306 Twining, 211 U.S. at 112.

307 Id. at 106.

308 See id. at 106-14.

${ }^{309}$ See id. at 123 (Harlan, J., dissenting) (referring to "the Star Chamber method of compelling an accused to be a witness against himself'); see also, e.g., IRVING BRANT, THE BLL OF RIGHTS: ITS ORIGN AND MEANING 380-85 (1965) (discussing the Star Chamber and the history of the privilege).

310 Twining, 211 U.S. at 113.

311 See id. at 123-24 (Harlan, J., dissenting) (quoting and discussing Boyd v. United States, 116 U.S. 616 (1886)). Boyd, of course, involved the Fifth Amendment's direct application to the federal government.

312 Twining, 211 U.S. at 127 (Harlan, J., dissenting). 
[1]f, prior to the adoption of the Fourteenth Amendment, it was one of the privileges or immunities of citizens of the United States that they should not be tried for crime in any court organized or existing under national authority except by a jury composed of twelve persons, how can it be that a citizen of the United States may be now tried in a state court .. . by eight jurors, when that Amendment expressly declares that "no State shall make or enforce any law which shall abridge the privileges or immunities of citizens of the United States"? 313

Harlan pointed out that the Court's reasoning left it powerless in the event "a state should prohibit the free exercise of religion; or abridge the freedom of speech or of the press," and he went on to summarize the entire Bill of Rights. ${ }^{314} \mathrm{He}$ wound up with a provocative hypothetical involving the establishment of religion:

Suppose the State of Utah should amend its Constitution and make the Mormon religion the established religion of the State, to be supported by taxation on all the people of Utah. Could its right to do so, as far as the Constitution of the United States is concerned, be gainsaid under the principles of the opinion just delivered? ... [C]ould not the [majority] opinion herein be cited as showing that the right to the free exercise of religion was not a privilege of a "citizen of the United States" within the meaning of the Fourteenth Amendment? ${ }^{315}$

Professor Amar, very surprisingly, used the latter passage to suggest that Justice Harlan may not have viewed the Establishment Clause as being properly incorporated in the Fourteenth Amendment. ${ }^{316}$ But Harlan's hypothetical, chosen to illustrate the dangers of not binding the states to the Bill of Rights, involved what

${ }^{313}$ Maxwell, 176 U.S. at 612 (Harlan, J., dissenting).

314 Id. at 615 (Harlan, J., dissenting).

315 Id. at 615-16 (Harlan, J., dissenting).

316 See AMAR, BILI OF RIGHTS, supra note 12, at 229; Amar, supra note 12, at 1271-72. Amar has questioned whether the Establishment Clause can properly be viewed as incorporated in the Fourteenth Amendment. See AMAR, BLL OF RIGHTS, supra note 12, at 246-57. But see Kurt T. Lash, The Second Adoption of the Establishment Clause: The Rise of the Nonestablishment Principle, 27 ARIZ. ST. L.J. 1085 (1995) (analyzing powerful reasons to conclude that it is properly incorporated); see also Andrew Koppelman, Akhil Amar and the Establishment Clause, 33 U. RICH. L. REV. 393 (1999). Harlan's Maxwell dissent, contrary to Amar's interpretation, is in fact strong evidence that the Establishment Clause was viewed in the late nineteenth century as properly incorporated, at least by those who generally favored incorporation. Senator Thomas M. Norwood (D-Ga.) and Rep. James B. Beck (D-Ky.), among the members of Congress embracing incorporation (and an incorporationist reading of Slaughter-House) in the early 1870s, expressly referred to the Establishment Clause as being among the Bill of Rights guarantees protected by the Amendment. See 2 CONG. REC. 342 (Dec. 19, 1873) (Rep. Beck); id. at app. 241 (Apr. 30 \& May 4, 1874) (Sen. Norwood). See generally Wildenthal, Lost Compromise, supra note 9, at Part III.A.1. 
would most apparently be a violation of the Establishment Clause. ${ }^{317}$ Amar argued that Harlan omitted nonestablishment from his catalog of Bill of Rights guarantees, 318 but the above-quoted hypothetical itself paraphrased the key language of the clause concerning "established religion."319

Indeed, Justice Harlan's broader point was that failing to incorporate any one constitutional guarantee tended to imply permission for states to violate others. But all those guarantees, he maintained, "are equally protected by the Constitution. No judicial tribunal has authority to say that some of them may be abridged by the states while others may not be abridged." 320 Thus, in Twining, "constrained by a sense of duty,"321 Harlan declared that

as immunity from self-incrimination was recognized in the Fifth Amendment . . . and placed beyond violation by any Federal agency, it should be deemed one of the immunities of citizens of the United States which the Fourteenth Amendment in express

317 Amar made much of the fact that Harlan's hypothetical involved taxation to support religion, rather than a mere symbolic declaration, implying that this suggested a Free Exercise Clause rather than an Establishment Clause violation. See AMAR, BILL OF RIGHTS, supra note 12, at 229; Amar, supra note 12, at 1272. But this seems rather strained. It is doubtful that mere expenditure of public funds for religious purposes, without more, would be found to violate the Free Exercise Clause standing alone. Harlan's own suggestion that his hypothetical might violate the Free Exercise Clause is best explained by the common tendency to lump together the two religion clauses. See infra note 319 .

318 See AMAR, BILL OF RuGHTS, supra note 12, at 229; Amar, supra note 12, at 1271.

${ }^{319}$ Maxwell, 176 U.S. at 615 (Harlan, J., dissenting). It thus misreads (or at least overreads) Harlan to say that he "deci[ded] to characterize this hypothetical ... as violating free exercise rather than nonestablishment principles." AMAR, BILL OF RIGHTS, supra note 12, at 229 (emphasis added); see also Amar, supra note 12, at 1272. Amar characterized this "decision" as "subtle but significant." AMAR, BLL OF RIGHTS, supra note 12, at 229; see also Amar, supra note 12, at 1272. So subtle as to be nonexistent, in my view. Harlan implied a violation of the Establishment Clause at least equally strongly (more strongly, in my view), by referring explicitly to Utah's hypothetical decision to "make the Mormon religion the established religion of the State." Maxwell, 176 U.S. at 615 (Harlan, J., dissenting). It has long been common to lump together the two religion guarantees, and to treat the Establishment Clause as merely providing further protection for religious freedom in general, which indeed it does. See, e.g., Everson v. Bd. of Educ., 330 U.S. 1, 63 (1947) (Rutledge, J., dissenting) (in an Establishment Clause case involving a subsidy of schoolchildren's bus fares and no plausible Free Exercise Clause violation, arguing that the subsidy should be struck down, and referring to the need "to prevent the first experiment upon our liberties; ... [w]e should not be less strict to keep strong and untarnished the one side of the shield of religious freedom than we have been of the other").

${ }^{320}$ Maxwell, 176 U.S. at 616 (Harlan, J., dissenting).

${ }^{321}$ Twining, 211 U.S. at 114 (Harlan, J., dissenting). 
terms forbids any State from abridging —as much so, for instance, as the right of free speech.... ${ }^{322}$

Justice Harlan's references to freedom of speech in both Maxwell and Twining were not academic. The year before Twining, he dissented yet again in defense of the Bill of Rights. In Patterson v. Colorado, ${ }^{323}$ an amazing decision remarkably little-noted today, the majority dismissed a newspaper publisher's challenge to a Colorado Supreme Court order convicting him of criminal contempt and fining him one thousand dollars - without even allowing a defense of truth - for criticizing one of its rulings. ${ }^{324}$ The author of the U.S. Supreme Court's opinion was none other than Justice Holmes, the reputed "Great Dissenter" and supposed defender of free expression. ${ }^{325} \mathrm{He}$ skirted the incorporation issue by assuming arguendo that the First Amendment applied. ${ }^{326}$ Even on that assumption, the Court held, in reliance on Blackstone and the old common law of criminal libel, that only prior restraints on the press, not subsequent punishments, were forbidden, and that "the subsequent punishment may extend as well to the true as to the false." 327

${ }^{322}$ Id. at 124 (Harlan, J., dissenting).

323205 U.S. 454 (1907).

${ }^{324}$ Thomas M. Patterson was the publisher of the Denver Times and the Rocky Mountain News, and Democratic U.S. Senator from Colorado from 1901 to 1907 . He was incensed at the state court majority for invalidating, on highly questionable grounds, a recent referendum granting home rule to Denver, thereby nullifying several local elections. His papers ridiculed the state judges in editorials, cartoons, and letters, as tools of a Republican political machine controlled by utility interests. See id. at 458-59; People v. News-Times Publishing Co., 84 P. 912 (Colo. 1906), writ of error dismissed for want of jurisdiction sub nom. Patterson v. Colorado, 205 U.S. 454 (1907); id. at 956 (Steele, J., dissenting); see also BRANT, supra note 309, at 393-94; DAVD M. RABBAN, FREE SPEECH N ITS FORGOTIEN YEARS 132-34 (1997); U.S. ELECTONS, supra note 159 , at 787.

325 See, e.g., SHELDON M. NOVICK, HONORABLE JUSTICE: THE LIFE OF OLIVER WENDELL HOLMES 321-32 (1989) (discussing Holmes's role in World War I free speech cases); RABBAN, supra note 324 , at 279-98, 342-71 (same).

${ }^{326}$ See Patterson, 205 U.S. at 462 :

We leave undecided the question whether there is to be found in the Fourteenth Amendment a prohibition similar to that in the First. But even if we were to assume that freedom of speech and freedom of the press were protected from abridgments on the part not only of the United States but also of the States, still we should be far from the conclusion that [Patterson] would have us reach.

327 Id. (citing, e.g., 4 WLLIAM BLACKSTONE, COMMENTARIES *150); see also RABBAN, supra note 324 , at $133-34$. 
Justice Harlan, by contrast, not only found the First Amendment binding on the states, ${ }^{328}$ he boldly rejected the old, restrictive, common-law view of press freedom:

I cannot assent to th $[\mathrm{e}]$ view ... that the legislature may impair or abridge the rights of a free press and of free speech whenever it thinks that the public welfare requires that to be done. The public welfare cannot override constitutional privileges, and if the rights of free speech and of a free press are, in their essence, attributes of national citizenship, as I think they are, then neither Congress nor any State since the adoption of the fourteenth Amendment can, by legislative enactments or by judicial action, impair or abridge them. In my judgment the action of the court below was in violation of the rights of free speech and a free press as guaranteed by the Constitution....

... It is, I think, impossible to conceive of liberty, as secured by the Constitution against hostile action, whether by the Nation or by the States, which does not embrace the right to enjoy free speech and the right to have a free press. ${ }^{329}$

These were striking words indeed from a Justice in his twilight years, coming more than a decade before Judge Learned Hand's groundbreaking opinion in the Masses case ${ }^{330}$ and Justice Holmes's "great dissent" in Abrams v. United States. 331 They echoed one of the core imperatives of the Civil War-Era Republicans who gave birth to the Fourteenth Amendment. ${ }^{332}$ It was not until a generation after Justice Harlan's cry in the wilderness in Patterson that the Court began to haltingly re-incorporate the First Amendment into the Fourteenth, ${ }^{333}$ thereby beginning the slow and difficult journey back toward the lost compromise of Slaughter-House.

328 See Patterson, 205 U.S. at 463-64 (Harlan, J., dissenting).

329 Id. at 465 (Harlan, J., dissenting). Justice Brewer also dissented, in a brief separate opinion, but he stated that he did so "[w]hile not concurring in the views expressed by Mr. Justice Harlan." Id. (Brewer, J., dissenting). Brewer felt the Court should have granted the writ of error and addressed the case more fully on the merits, since Patterson's claim was not "a frivolous one." Id.

330 See Masses Publ'g Co. v. Patten, 244 F. 535 (S.D.N.Y.) (Hand, J.), rev'd, 246 F. 24 (2d Cir. 1917). This was the shortlived district court ruling that attempted to put a speechprotective gloss on wartime sedition laws, and which has been credited with helping to lay the foundation of the modem constitutional law of free speech. See GUNTHER \& SULLIVAN, supra note 12, at 1044-50; GERALD GUNTHER, LEARNED HAND: THEMAN AND THE JUDGE 151-70 (1994); Gerald Gunther, Learned Hand and the Origins of Modern First Amendment Doctrine: Some Fragments of History, 27 STAN. L. REv. 719 (1975); see also RABBAN, supra note 324, at 255-69.

331250 U.S. 616, 624 (1919) (Holmes, J., joined by Brandeis, J., dissenting); see also RABBAN, supra note 324, at 342-71.

332 See Wildenthal, Lost Compromise, supra note 9, at 1075 n.87 (collecting scholarship demonstrating that concerns about freedom of speech were central to the proposal and adoption of the Fourteenth Amendment).

333 See infra note 376. 
John Marshall Harlan died in office on October 14, 1911, not quite three years after Twining was decided, ${ }^{334}$ seemingly the last defender of the incorporationist faith. That same year, an ambitious young lawyer named Hugo L. Black-born in a frontier hamlet called Harlan "in the hills of Alabama in the troublesome times of Reconstruction"335_was appointed police court judge in Birmingham, Alabama. ${ }^{336}$

\section{THE BEGINNINGS OF A NEW SONG:337 $1947,1969,1999$, AND BEYOND}

The story of the Fourteenth Amendment is part of the great story of liberty... . It is a story well worth telling, particularly today, when study of the history of liberty is neglected and when guarantees are likely to be dismissed as mindless technicalities. For individuals, for families, and for nations, the stories we tell about our past are important ways of understanding our identity. ${ }^{338}$

This article's reappraisal of the early debate over incorporation demonstrates that Justice Black's 1947 Adamson dissent ${ }^{339}$ was neither a radical innovation nor an anachronistic afterthought. It appeared "activist" in a judicial sense only because of the weight of erroneous precedent standing in the way. The vociferous denials of incorporation by Justice Black's twentieth-century opponents-Justice Frankfurter, Professors Fairman and Morrison, and (most ironically) the second Justice Harlan prominent among them-were the true anachronisms.

Let us pause and look back over these forty years of debates and decisions from 1868 to 1908, in the halls of Congress and at the bar of the Supreme Court. ${ }^{340}$ What does that history tell us about the argument of Professors Fairman ${ }^{341}$ and

334 See OXFORD SUPREME COURT, supra note 37, at 968; Twining, 211 U.S. at 78.

335 BLACK, supra note 182, at 65; see also NEWMAN, supra note 85, at 3; DUNNE, supra note 85 , at $85-89$. Justice Black's birth year of 1886 was actually a bit past the traditionally identified end of Reconstruction, in 1877, but not by much.

336 See NEWMAN, supra note 85, at 29-30; DUNNE, supra note 85, at 97-99.

337 See supra note 277. Scotland's new song began on July 1, 1999, with the opening of the first Scottish Parliament in almost three hundred years, a reminder that constitutional moments need not be lost forever, and that even the century and one-third that have elapsed since the adoption of the Fourteenth Amendment are not so very long by the standards of America's ancestral lands. See A Moment Anchored in Scotland's History, The Scotsman, July 2, 1999, at 1.

338 Curtis, Resurrecting, supra note 12 , at 4.

339 See supra note 28.

340 See generally supra Parts II-IV; Wildenthal, Lost Compromise, supra note 9.

341 See Fairman, supra note 27, at 116 \& n.306, 132-34, 137. 
Morrison $^{342}$ that incorporation was, on the whole, a theory mysteriously missing in action from the discourse of judges and lawyers of that time? It has refuted that argument as to the judges. That incorporation was ultimately rejected by the courts of that era is undeniable. But it adds unwarranted insult to injury to disparage the theory as not even seriously entertained. The judges supporting incorporation were right, and they explained why quite convincingly. Their opponents were wrong, and furthermore, rarely bothered to engage the supporters in any serious discussion of the issue. As we all know, it is ultimately having five votes, not the best argument on the merits, that ensures victory on the Supreme Court. The anti-incorporationists had those five votes in 1892, as they did in 1947.343

What about the lawyers? Professor Morrison suggested that incorporation was simply not "abroad" as an idea among them. ${ }^{344}$ One might begin to address this argument by noting that most constitutional claims involving the Fourteenth Amendment and the Bill of Rights are brought by convicted criminals or others likely to be without substantial means. Hiring a lawyer to take an appeal (especially to the Supreme Court) was then, as it is today, an expensive proposition. Today, the indigent defendant is provided with a free attorney at trial and on the first appeal of right, ${ }^{345}$ but that long postdates the late nineteenth century. Today, unlike then, there is a veritable army of public interest lawyers and organizations ready to litigate pro bono almost any constitutional claim of broad interest. ${ }^{346}$ Today, many such claims are brought pursuant to federal habeas corpus jurisdiction and the federal Declaratory Judgment Act. Habeas corpus relief in federal court for persons held in state custody was statutorily created in 1867,347 but it was not until well into the twentieth century that the statute was interpreted to go beyond challenges to the jurisdiction of the state court, to reach most violations of federal constitutional

342 See Morrison, supra note 26, at 147 (asserting "failure of ... counsel" in Hurtado "to bring up the incorporation argument"); $i d$. at 151 (asserting that "[i]n view of the long line of cases ... in which the question could have been raised ... the conclusion is irresistible that it was not generally supposed that the [Fourteenth] Amendment incorporated the Bill of Rights"); id. at 160 (again asserting repeated "failure of counsel ... even to raise the question" and "lack of any ... understanding [in favor of incorporation] on the part of . . . legal contemporaries").

343 See Adamson v. California, 332 U.S. 46 (1947); O'Neil v. Vermont, 144 U.S. 323 (1892).

344 See Morrison, supra note 26, at 151.

345 See Gideon v. Wainwright, 372 U.S. 335 (1963); Douglas v. California, 372 U.S. 353 (1963).

346 See, e.g., RABBAN, supra note 324, at 299-341 (describing origins of American Civil Liberties Union and modern civil liberties movement during and after World War I).

${ }^{347}$ Act of Feb. 5, 1867, ch. 28, § 1, 14 Stat. 385 (codified at 28 U.S.C. § 2254). 
rights. ${ }^{348}$ The Declaratory Judgment Act was not passed until 1934.349 Furthermore, many nineteenth-century lawyers had little or no training in constitutional law, if they had even attended law school at all. ${ }^{350}$ And there is always, finally, sheer incompetence, which demonstrably afflicted the lawyering (even at the Supreme Court level) in at least three of the cases discussed in this article and its predecessor. ${ }^{351}$

But enough of excuses. When we survey the arguments nineteenth-century lawyers actually made, what do we find? We find some of them expressly advocating or at least accepting incorporation during the five years after the Fourteenth Amendment's adoption in 1868, 352 including in Slaughter-House, the first Supreme Court decision to address the scope of the Amendment. 353 Dean Richard Aynes has noted that, of the four legal scholars who seem to have written constitutional law treatises contemporary with the adoption of the Fourteenth

348 See Charles AlaN Wright, LAW OF FEDERAL COURTs § 53, at 350-54 (5th ed. 1994); see also Wright v. West, 505 U.S. 277, 285-86 (1992) (plurality opinion of Thomas, J., joined by Rehnquist, C.J., and Scalia, J.); id. at 299 (O’Connor, J., joined by Blackmun and Stevens, JJ., concurring in the judgment).

349 Act of June 14, 1934, ch. 512, 48 Stat. 955 (codified at 28 U.S.C. $\$ \$ 2201-2202$ ). Prior to the Court's decision in Nashville, Chattanooga \& St. Louis Ry. v. Wallace, 288 U.S. 249 (1933), it was thought that the constitutionally required "case or controversy," see U.S. CoNST. art. III, § 2, might be lacking in lawsuits seeking only declaratory judgments. See WRIGHT, supra note $348, \S 12$, at $66-67 ; i d$., $\S 100$, at 712 .

350 See LAWRENCE M. FRIEDMAN, A History OF AMERICAN LAW 606-07 (2d ed. 1985) (noting that the overwhelming majority of lawyers in the mid-nineteenth century were self-taught or trained by clerking in law offices, though the trend toward law school education became strong by 1900); id. at 614 (noting that constitutional law was, for a time, removed entirely from the Harvard curriculum under Dean Christopher Columbus Langdell); Paul D. Carrington, Law as "The Common Thoughts of Men": The Law-Teaching and Judging of Thomas McIntyre Cooley, 49 STAN. L. REV. 495, 515-16 (1997) (noting that "Langdell did not regard [constitutional law] as law at all" and that it was not taught at Harvard during the 1870s). Furthermore, the multitude of electronic and print resources that modem lawyers rely on to keep up to date with court decisions-including, it sometimes seems, hanging on every nuance of phrasing uttered by the Supreme Court—did not then exist.

351 This is illustrated, for example, by the attomey in Twitchell v. Pennsylvania, 74 U.S. (7 Wall.) 321 (1869), who not only failed to invoke the incorporation theory on behalf of his death-row client, but neglected (even while claiming a due process violation) to invoke the newly ratified Fourteenth Amendment Due Process Clause. See Wildenthal, Lost Compromise, supra note 9, at Part II.A; see also supra note 129 (discussing Presser Defendant's Brief, supra note 129); supra note 247 (discussing McElvaine Appellant's Brief, supra note 247).

352 See Wildenthal, Lost Compromise, supra note 9, at Part II.A.

353 See id. at Part II.D (discussing Slaughter-House briefs). 
Amendment, three strongly supported incorporation. ${ }^{354}$ In the early 1870 s, we find lawyers in Congress, across the political spectrum, embracing incorporation. ${ }^{355}$ All of this was overlooked by Professors Fairman and Morrison. One legal commentator, writing in 1879 and criticizing the narrow reading of the Privileges and Immunities Clause which had by then taken hold on the Court, observed:

Ninety-nine out of every hundred educated men, upon reading [the Clause], would at first say that it forbade a state to make or enforce a law which abridged any privilege or immunity whatever of one who was a citizen of the United States; and it is only by an effort of ingenuity that any other sense can be discovered that it can be forced to bear. 356

Beaten back by the Court's unexplained and gratuitous undermining of the incorporation theory in cases like Walker and Cruikshank, ${ }^{357}$ and with the Court

354 See Aynes, Bingham, supra note 30, at 83-91 (discussing TMOTHY FARRAR, MANUAL OF THE CONSTITUTION OF THE UNITED STATES (1867 \& 3d ed. 1872), GEORGE W. PASCHAL, THE CONSTITUTION OF THE UNITED STATES DEFINED AND CAREFULLY ANNOTATED (1868), and JOHN N. POMEROY, AN INTRODUCTION TO THE CONSTITUTIONAL LAW OF THE UNTTED STATES (1868)); see also CURTIS, NO STATE, supra note 12, at 172-73 (discussing POMEROY, supra). Cf. Aynes, Bingham, supra note 30, at 91-94 (discussing treatises by Thomas M. Cooley); Wildenthal, Lost Compromise, supra note 9, at Part III.A.3 (same).

355 See Wildenthal, Lost Compromise, supra note 9, at Parts II.A and III.A.1.

356 William L. Royall, The Fourteenth Amendment: The Slaughter-House Cases, 4 SOUTHERNL. REV. (N.S.) 558, 563 (1879), quoted in Adamson v. Califomia, 332 U.S. 46, 7576 n.6 (1947) (Black, J., dissenting). Royall was no Radical Republican, but rather-like John Randolph Tucker, see supra Part II.D-a Democrat and former Confederate. See Aynes, Miller, supra note 12, at 681-82 \& n.398. Royall seemed to accept the conventional anti-incorporationist reading of Slaughter-House (while disagreeing with Slaughter-House so read), but his reading was obviously colored by the intervening decisions in Cruikshank and Walker, which he also discussed, as well as by an unpublished, anti-incorporationist 1878 circuit court decision by Chief Justice Waite (acting as Circuit Justice). See Royall, supra, at 559-62. Royall mistakenly asserted that "no one of the distinguished counsel who argued" Slaughter-House "consult[ed] the proceedings of the Congress which proposed [the Fourteenth] [A]mendment." Id. at 563. But see Wildenthal, Lost Compromise, supra note 9, at Part II.D. Royall himself offered a very capable discussion of the legislative history, including the key speeches by Rep. John A. Bingham (R-Ohio) and Sen. Jacob M. Howard (R-Mich.). See Royall, supra, at 563-75; Wildenthal, Lost Compromise, supra note 9, at Part I.B. Royall took pains to argue that the incorporationist view of the Fourteenth Amendment, which he favored, was consistent with "the purest principles of Democracy" (his capitalization indicating a reference to the political principles of the Democratic Party). Royall, supra, at 584. He did not cite, however, and may have been unaware of, the numerous statements by Democratic members of Congress in the early 1870 s endorsing not only the incorporationist view of the Fourteenth Amendment, but also an incorporationist reading of Slaughter-House. See Wildenthal, Lost Compromise, supra note 9, at Parts II.A and III.A.1.

357 See Wildenthal, Lost Compromise, supra note 9, at Parts III.B-IV. 
and the nation generally turning against Reconstruction and any broad reading of the Reconstruction Amendments, 358 there was then a bit of a lull. Even in the Cruikshank litigation, however, Justice Bradley's circuit court opinion squarely endorsed incorporation. And of the four Supreme Court briefs filed on behalf of the Cruikshank defendants, who had every incentive to dispute incorporation, only one did so, while another actually endorsed incorporation. 359

In 1884, we again find incorporation being pressed, via the Due Process Clause, ${ }^{360}$ and then via the Privileges and Immunities Clause in $1886,3611887,362$ and the early $1890 \mathrm{~s}^{363}$ The theory was raised yet again in $1897,3641899,365$ $1900,3661904,{ }^{367} 1907,{ }^{368}$ and $1908 .{ }^{369}$ And those were just the occasions that produced significant discussion of the issue on the Supreme Court. ${ }^{370}$ Dean Aynes has noted that several leading legal scholars in the 1890s supported incorporation. ${ }^{371}$ And it was in 1908, the year of Twining and the nadir of the incorporation theory on the Court, that Horace Flack published his famous

358 See, e.g., Robert D. Goldstein, Blyew: Variations on a Jurisdictional Theme, 41 STAN. L. REV. 469, 526 (1989) (describing Court as "an ideological and political leader in the reaction to Reconstruction"); Michael W. McConnell, Originalism and the Desegregation Decisions, 81 VA. L. REV. 947, 1088-89 (1995). See generally FoNER, supra note 167, at 512-612; Michael W. McConnell, The Forgotten Constitutional Moment, 11 CONST. COMM. 115 (1994) (discussing the end of the Reconstruction Era and its relation to the Constitutional Moment theory).

359 See Wildenthal, Lost Compromise, supra note 9, at Part III.C.

360 See supra Part II.B (discussing Hurtado).

361 See supra Part II.C (discussing Presser).

362 See supra Part II.D (discussing Spies).

363 See supra Part III.A (discussing O'Neil, Eilenbecker, Miller, Kemmler, and McElvaine).

364 See supra Part III.B (discussing Chicago $B \& Q$ ).

365 See id. (discussing Brown).

366 See supra Part IV (discussing Maxwell).

367 See supra note 303 (discussing West).

368 See supra Part IV (discussing Patterson).

${ }^{369}$ See id. (discussing Twining).

370 See JAMES W. ELy, JR., THE CHIF JUSTICESHIP OF MELVILLE W. FULLER, 1888-1910 166 (1995) (noting that during the late nineteenth century, "[c]riminal defendants frequently argued that the privileges and immunities clause of the Fourteenth Amendment embraced at least some of the guarantees of the Bill of Rights").

371 See Aynes, Miller, supra note 12, at 682-83 (citing 1 JOHN W. BURGESS, POLITICAL SCIENCE AND COMPARATIVE CONSTITUTIONAL LAW 228-30 (1890), and WILLIAMD. GUTHRIE, LECTURES ON THE FOURTEENTH AMENDMENT 58-59 (1898)). Justice Black cited what appears to have been the same work by Guthrie in Adamson v. California, 332 U.S. 46, 73 (1947) (Black, J., dissenting). 
argument in favor of incorporation, an argument relied upon by Justice Black in 1947.372

One is tempted to ask what more Professors Fairman and Morrison wanted. This author's conclusion is that the lawyers of the late nineteenth century, in the context of their time, gave incorporation a pretty good college try. Moreover, they were fairly persistent in the face of a Supreme Court that repeatedly demonstrated its indifference or outright hostility. The key voting and equality reforms of the Reconstruction Amendments were also, after all, treated with indifference or outright hostility during the late nineteenth century by the Court-and by most of the nation-and went effectively unenforced until almost a century later. This makes the failure of incorporation to gain ultimate acceptance during that era less peculiar, less surprising, and less relevant to its intrinsic merits.

As Professor Curtis has noted, "[f]or a brief shining moment during and after the Civil War, protection of Blacks had been associated with the cause of the Union. By the mid-1870s protection of Blacks seemed to disrupt national unity, and the commitment to protection of their rights faded away as quickly as it had come."373 Something similar took place with regard to incorporation. Bom in the epic debates of the 1860 s, it enjoyed a brief heyday in the early 1870 s. It was a reassuring, textualist alternative to the radical invitations of nationalist libertarians like Justice Field. But it got caught up in the general retrenchment of federal power associated with the end of Reconstruction. Attention was not paid. Care was not taken. For a conservative Court, zealous in defense of private property and corporate rights, but indifferent or hostile to individual liberty in the broader sense, incorporation was a bother. Shoddy, ill-begotten precedents like Walker and Cruikshank provided the excuse to ignore the true consensus and compromise of Slaughter-House. Justice Harlan, and to a lesser but still admirable extent Justice Field, saw what was at stake. But they were only two Justices. And then only one. The moment did not last.

Usually, ideas that undergo a fundamental change in acceptance by the legal order progress gradually over time from radical innovation to conservative verity. It was somehow the reverse for the incorporation theory. It progressed from being a minimum, uncontroversial compromise embraced by racist reactionaries and procivil-rights progressives alike in the early 1870 s, to a theory widely scorned in the late 1940s as virtually an attempted constitutional coup d'état by the four most liberal Justices on the Court. Two of those Justices-Black and Douglas-survived into the 1970s, continuing to press the cause, which largely triumphed in substance though not in strict theory during the Warren Court judicial revolution of the 1960 s. Even then, however, and even today to a large extent, the myth has persisted-at least among many conservatives and purported adherents of "judicial restraint" and

372 See HorACE E. FlACK, THE AdOPTION OF THE FOURTEENTH AMENDMENT 94 (1908), cited in Adamson v. Califomia, 332 U.S. 46, 72 n.5, 109-10 (1947) (Black, J., dissenting).

373 CURTIS, No STATE, supra note 12, at 180. 
"original understanding" approaches to constitutional interpretation-that this revolution was the adventurous, ill-founded, and unwise product of modern activist judges. In reality, it was, quite the contrary, the vindication -albeit long-overdue and incomplete - of the understanding embraced by legislators and judges, visionaries and reactionaries alike, in the 1860s and 1870s.

If 1908 was incorporation's nadir and 1947 a dramatic near-miss, 1969 was its zenith. The year before, Justices Black and Douglas had noted their satisfaction with the process of "selective" incorporation, which had "the virtue of having already worked to make most of the Bill of Rights' protections applicable to the States"-although, they pointedly added, it was "perhaps less historically supportable than complete incorporation." 374 The Court's 1969 decision in Benton v. Maryland ${ }^{375}$ was the capstone and conclusion of that chapter in the incorporation saga. The case overflowed with historical symbolism and ironies. The Court's opinion-the last (to date) to incorporate a Bill of Rights guarantee 376 — was written

374 Duncan v. Louisiana, 391 U.S. 145, 171 (1968) (Black, J., joined by Douglas, J., concurring); see also BLACK, supra note 182, at 34-42.

375395 U.S. 784 (1969).

376 See Chicago, Burlington \& Quincy R.R. Co. v. Chicago, 166 U.S. 226, 241 (1897) (incorporating right to just compensation for takings of private property); Gitlow v. New York, 268 U.S. 652, 666 (1925) ("assum[ing]" that freedoms of speech and press are incorporated); Stromberg v. California, 283 U.S. 359, 368 (1931) (so holding as to freedom of speech); Near v. Minnesota, 283 U.S. 697, 707 (1931) (same as to freedom of press); De Jonge v. Oregon, 299 U.S. 353, 364-66 (1937) (incorporating rights of peaceable assembly and petition); Cantwell v. Connecticut, 310 U.S. 296, 303 (1940) (same as to free exercise of religion and rule against establishment of religion); In re Oliver, 333 U.S. 257, 266-73 (1948) (same as to right to public trial); id. at 273 (same as to defendant's "right to reasonable notice of a charge against him," i.e., right to be informed of nature and cause of accusation); Wolf v. Colorado, 338 U.S. 25, 27-28, 33 (1949) (incorporating "security of . . . privacy against arbitrary intrusion by the police . . . at the core of the Fourth Amendment," but not exclusionary rule for evidence seized in violation thereof); Mapp v. Ohio, 367 U.S. 643, 654-60 (1961) (incorporating right to exclusion of evidence seized in violation of Fourth Amendment); Robinson v. Califomia, 370 U.S. 660, 66667 (1962) (same as to immunity from cruel and unusual punishments); Gideon v. Wainwright, 372 U.S. 335, 342-45 (1963) (same as to right to counsel, including appointed counsel for indigent defendants); Malloy v. Hogan, 378 U.S. 1, 8-11 (1964) (same as to privilege against selfincrimination); Pointer v. Texas, 380 U.S. 400, 403 (1965) (same as to right of confrontation); Klopfer v. North Carolina, 386 U.S. 213, 222-23 (1967) (same as to right to speedy trial); Washington v. Texas, 388 U.S. 14, 17-19 (1967) (same as to right to compulsory process to obtain favorable witnesses); Duncan v. Louisiana, 391 U.S. 145, 148-50 (1968) (same as to right to criminal jury trial); Benton v. Maryland, 395 U.S. 784, 793-96 (1969) (same as to immunity from double jeopardy). The Court's incorporation of the right to counsel had its gradual start in Powell v. Alabama, 287 U.S. 45 (1932), but was not fully accomplished until Gideon. The Court in Robinson appeared to rely on Louisiana ex rel. Francis v. Resweber, 329 U.S. 459 (1947), as having already incorporated immunity from cruel and unusual punishments. See Robinson, 370 U.S. at 666; see also id. at 675 (Douglas, J., concurring). Justice Reed's plurality opinion in 
by Justice Thurgood Marshall, the first African-American to ascend the high bench. Dissenting yet again was the second Justice Harlan, ${ }^{377}$ whose grandfather, as we have seen, was a repeated dissenter on the other side of the issue and wrote the first opinion of the Court to hold that a Bill of Rights guarantee fell within the scope of the Fourteenth Amendment. ${ }^{378}$ Both, it would seem, lived in the wrong era. And, of course, the first Justice Harlan's dissent demanding equality under law for African-Americans was resurrected in a case argued by the future Justice Marshall. 379

Benton moved far toward embracing, at long last, the logic of total and textual incorporation. The Court flatly repudiated Palko v. Connecticut, ${ }^{380}$ the case that forged the "fundamental fairness" approach to selective incorporation, declaring that "this Court has 'increasingly looked to the specific guarantees of the [Bill of Rights]"'381 in resolving the incorporation issue. "Once it is decided that a particular Bill of Rights guarantee is 'fundamental to the American scheme of justice,' the same constitutional standards apply against both the State and Federal Governments. Palko's roots had thus been cut away years ago. We today only recognize the inevitable." 382 It is, of course, difficult to see why any guarantee would ever have been enshrined in the Bill of Rights if it were not deemed "fundamental" by Americans. The only real difference between Benton's approach and total incorporation is respect for stare decisis with regard to the three Bill of Rights guarantees still specifically disincorporated in 1969 and today. 383

Yet, Benton also carried troubling portents for incorporation. The case was decided on the very day that Chief Justice Earl Warren stepped down and was

Resweber, however, merely "assum[ed] ... without so deciding" that this immunity was incorporated in the Fourteenth Amendment, and did not speak for the Court in any event. See Resweber, 329 U.S. at 462 (Reed, J., joined by Vinson, C.J., and Black and Jackson, JJ.). Furthermore, the majority denied relief to the claimant. See id. at 465-66 (Reed, J.); id. at 471-72 (Frankfurter, J., concurring [in the judgment]). For a catalog of all twenty-four privileges and immunities secured by the Bill of Rights, see supra note 106.

377 Benton, 395 U.S. at 801-13 (Harlan, J., joined by Stewart, J., dissenting).

378 See supra Part III.B (discussing Chicago B\&Q).

379 Compare Brown v. Bd. of Educ., 347 U.S. 483, 484 (1954) (Thurgood Marshall appearing for plaintiffs), with Plessy v. Ferguson, 163 U.S. 537, 552-64 (1896) (Harlan, J., dissenting). See generally RICHARD KLUGER, SIMPLE JUSTICE: THE HISTORY OF BROWNV. BOARD OF EDUCATTON AND BLACK AMERICA'S STRUGGLE FOR EQUALITY (1975).

380 302 U.S. 319 (1937).

381 Benton, 395 U.S. at 794 (quoting Washington v. Texas, 388 U.S. 14, 18 (1967)).

382 Id. at 795 (quoting Duncan, 391 U.S. at 149).

383 See Edwards v. Elliott, 88 U.S. (21 Wall.) 532, 557 (1874) (civil jury trial); Walker v. Sauvinet, 92 U.S. 90, 92-93 (1876) (same); United States v. Cruikshank, 92 U.S. 542, 553 (1876) (right to bear arms); Presser v. Illinois, 116 U.S. 252, 264-68 (1886) (same); Hurtado v. California, 110 U.S. 516, 538 (1884) (grand jury indictment). 
succeeded by Chief Justice Warren E. Burger, thus depriving the liberals of their majority on the Court. ${ }^{384}$ Over the next decade, the majority, while not disincorporating outright any Bill of Rights guarantee, cut back significantly on the application to the states of the Sixth Amendment right to criminal jury trial. ${ }^{385}$ Although there presently seems no danger of any further rollback of incorporation, one wonders how the Court will resolve the remaining open questions in this area. These include the three Bill of Rights guarantees that the Court has so far neither incorporated nor disincorporated, ${ }^{386}$ and the six other personal rights scattered in the original Constitution. 387

384 See OXFORD SUPREME COURT, supra note 37, at 970. Justice Abe Fortas, generally regarded as another liberal pillar of the Warren Court, had resigned the month before. See id. That left only Justices Black, Douglas, Brennan, and Marshall among those generally placed in the liberal wing. Black retired in 1971 and Douglas in 1975. See id. at 969-70.

385 See Apodaca v. Oregon, 406 U.S. 404 (1972) (upholding, 5-4, state court conviction by non-unanimous verdict, even though five Justices adhered to view that Sixth Amendment required unanimous verdict in federal court and eight Justices adhered to view that Sixth and Fourteenth Amendment jury guarantees were identical); id. at 366, 369-77 (Powell, J., concurring in the judgment) (casting swing vote interpreting Fourteenth Amendment as not fully incorporating Sixth Amendment jury trial guarantee); Ludwig v. Massachusetts, 427 U.S. 618 (1976) (upholding, 5-4, state procedure requiring initial bench trial of certain crimes, subject to defendant's right to de novo retrial by jury, while leaving undisturbed precedent finding similar procedure in District of Columbia invalid under Sixth Amendment); see also Williams v. Florida, 399 U.S. 78 (1970) (ruling that jury of six rather than twelve did not violate Sixth or Fourteenth Amendments). Justice Marshall, in an opinion that would surely have met the approbation of the elder Justice Harlan, dissented alone from Williams's dilution of the right to jury trial. See Williams, 399 U.S. at 116-17 (Marshall, J., dissenting). The elder Harlan had written the Court's opinion in Thompson v. Utah, 170 U.S. 343, 349-50 (1898) (overruled by Williams), holding, in a criminal case originating when Utah was still a federal territory directly subject to the Sixth Amendment, that the right necessarily presupposed a jury of twelve, for reasons rooted in Anglo-American legal history. The younger Justice Harlan stood by his grandfather on this issue, sharply protesting the Williams Court's dilution of the Sixth Amendment, though he concurred in the result because of his view that the Fourteenth Amendment did not incorporate the Sixth. See Williams, 399 U.S. at 117, 12229 (Harlan, J., concurring in the result). In case it is not clear from the foregoing, I happen to strongly agree with both Justices Harlan on the Sixth Amendment issue, and with Justice Marshall and the elder Harlan on the Fourteenth.

386 These are the Third Amendment freedom from quartering of soldiers and the Eighth Amendment immunities from excessive bail and excessive fines. See supra note 106.

387 These may be numbered as follows: (1) rule against suspension of the writ of habeas corpus, see U.S. CoNST. art. I, $\S 9$, cl. 2; (2) right to criminal jury trial, id. art. III, § 2, cl. 3; (3) immunity from liability for treason unless guilty of "levying War against [the United States], or... adhering to their Enemies, giving them Aid and Comfort," id. $\S 3, \mathrm{cl}$. 1; (4) immunity from conviction for treason "unless on the Testimony of two Witnesses to the same overt Act, or on Confession in open Court," id.; (5) immunity from any "Attainder of Treason... work[ing] Comuption of Blood, or Forfeiture except during the Life of the Person attainted," id. § 3, cl. 2; 
To address the former three first, it seems doubtful that the Court will face in the foreseeable future any issue arising under the Third Amendment's prohibition of peacetime quartering of soldiers in private homes. With regard to excessive bail and excessive fines under the Eighth Amendment, it seems hard to believe that the Court would not incorporate those rights if ever confronted with the issue, especially given that the remaining Eighth Amendment guarantee, against cruel and unusual punishments, has long been incorporated. ${ }^{388}$ The Court has, in fact, expressed in dicta an assumption that the Excessive Bail Clause applies to the states through the Fourteenth Amendment. ${ }^{389}$ Justices Sandra Day O'Connor and John Paul Stevens have expressly endorsed incorporation of the Excessive Fines Clause. ${ }^{390}$ The Court, in a 1983 opinion by Justice O'Connor, struck down a state's automatic imposition of a prison term on an indigent defendant for failure to pay a fine, ${ }^{391}$ and it recently threw out a federal fine on grounds of excessiveness for the first time ever. 392

With regard to the six guarantees in the Constitution of 1787 , the three closely interlinked provisions dealing with treason seem as unlikely as the Third Amendment to arise any time soon in a state context. ${ }^{393}$ The Article III guarantee

and (6) immunity from any religious test for federal office, $i d$. art. VI, cl. 3. The original Constitution also guarantees three individual rights against both federal and state violation: (1) immunity from bills of attainder, (2) immunity from ex post facto laws, and (3) rule against grants of nobility. Id. art. I, $\S 9, \mathrm{cls} .3,8, \S 10, \mathrm{cl}$. 1 . The amendments provide such dual protection to another eight rights: (1) prohibition of slavery and involuntary servitude, id. amend. XIII, $\S 1$; (2) right to United States citizenship by birth within United States jurisdiction, id. amend. XIV, $\S 1$; (3) right of United States citizens to state citizenship by residence within any state, $i d$;; (4) right not to be deprived of "life, liberty, or property, without due process of law," id. amends. V and XIV, $\S 1 ;(5)$ right of United States citizens to vote without regard to "race, color, or previous condition of servitude," $i d$. amend. XV, $\S 1 ;(6)$ right of United States citizens to vote without regard to sex, id. amend. XIX, $\S 1 ;$ (7) right of United States citizens to vote in federal elections without regard to "failure to pay any poll tax or other tax," $i d$. amend. XXIV, $\S 1$; and (8) right of United States citizens aged 18 and older to vote without regard to age, $i d$. amend. XXVI, § 1. Finally, the Constitution guarantees two individual rights against state but not federal violation: (1) immunity from impairment of contracts, $i d$. art. I, $\S 10, \mathrm{cl} .1$; and (2) right to "equal protection of the laws," id. amend. XIV, $\S 1$. But see Bolling v. Sharpe, 347 U.S. 497, 499-500 (1954) (holding that equal protection guarantee applies in substance to federal government).

388 See supra note 376.

389 See Schilb v. Kuebel, 404 U.S. 357, 365 (1971).

390 See Browning-Ferris Indus. of Vt., Inc. v. Kelco Disposal, Inc., 492 U.S. 257, 283-84

(1989) (O'Connor, J., joined by Stevens, J., concurring in part and dissenting in part).

391 See Bearden v. Georgia, 461 U.S. 660 (1983). The Court in Bearden relied on a combination of equal protection and generic due process analysis. See id. at 664-67.

392 See United States v. Bajakajian, 524 U.S. 321 (1998).

393 The only recent possibility that this author (tongue in cheek) can call to mind would be the abortive 1997 rebellion of the so-called "Republic of Texas," a crackpot militia group in the 
of criminal jury trial and the Article VI prohibition of any religious test for federal office were rendered mostly superfluous by the First and Sixth Amendments. Oddly enough, the Court in Ludwig v. Massachusetts ${ }^{394}$ cited the Article III Jury Clause as justifying a more stringent jury requirement in federal court. Ludwig narrowly upheld a state requirement that defendants in certain cases submit initially to a nonbinding bench trial, while distinguishing the Court's century-old opinion in Callan v. Wilson ${ }^{395}$-written by (who else?) the elder Justice Harlan-striking down a similar procedure in the District of Columbia. 396

The Ludwig majority argued that Callan need not be disturbed because "the sources of the right to jury trial in the federal courts ... include [the Article III clause,] ... which might"-might? - "be read as prohibiting, in the absence of a defendant's consent, a federal trial without a jury ...."397 This was puzzling at best, because the Sixth Amendment guarantee is in no way weaker than that of Article III, and in fact is considerably more detailed. ${ }^{398}$ In any event, Ludwig promptly added that the Article III clause "is, of course, not applicable to the States." 399 This did not follow and was not explained, but the issue seems mostly academic because the Sixth Amendment right has, of course, been incorporated. ${ }^{400}$

Davis Mountains of West Texas. See Texas: The Alamo, Again, ECONOMIST, May 3, 1997, at 25; Shutting Down a Siege, NEwSwEek, May 12, 1997, at 46; Out There, TEX. MONTHLY, June 1997, at 98 .

394427 U.S. 618 (1976).

395127 U.S. 540 (1888).

396 See Ludwig, 427 U.S. at 629-30. Cf. id. at 632 (Powell, J., concurring) (providing crucial vote for Court's 5-4 decision on ground that "the right to a jury trial afforded by the Fourteenth Amendment is not identical to that guaranteed by the Sixth Amendment'); id. at 632-38 (Stevens, J., joined by Brennan, Stewart, and Marshall, JJ., dissenting) (pointing out that state's requirement was either "totally irrational," or had impermissible purpose of "placing a burden on the exercise of the constitutional right").

397 Id. at 629-30.

398 Compare U.S. CoNST. art. III, $\S 2$, cl. 3 ("The Trial of all Crimes, except in Cases of Impeachment, shall be by Jury; and such Trial shall be held in the State where the said Crimes shall have been committed; but when not committed within any State, the Trial shall be at such Place or Places as the Congress may by Law have directed."), with id. amend. VI ("In all criminal prosecutions, the accused shall enjoy the right to a speedy and public trial, by an impartial jury of the State and district wherein the crime shall have been committed, which district shall have been previously ascertained by law ....") (emphases added).

${ }^{399}$ Ludwig, 427 U.S. at 630 . Technically speaking, this would thus qualify as the fourth federal right still specifically disincorporated from the Fourteenth Amendment by the Court. $C f$. supra note 383.

400 See Duncan v. Louisiana, 391 U.S. 145, 148-50 (1968). 
In Torcaso v. Watkins, 401 the Court, in an opinion by Justice Black, found unconstitutional a Maryland requirement that state officeholders declare a belief in God. Because Black held that this violated freedom of religion under the First and Fourteenth Amendments, ${ }^{402}$ he found it "unnecessary to consider [the] contention that [the Article VI Religious Test Clause] applies to state as well as federal offices." 403 But in light of Torcaso, that too seems academic. For most practical purposes, both the Article VI provision and the Article III Jury Clause have, in effect, been incorporated.

This leaves the guarantee in Article I, Section 9 against suspension of the writ of habeas corpus. The Slaughter-House majority, back in 1873, cited this as a federal privilege or immunity now protected against state infringement. ${ }^{404}$ To the extent that might be read-consistently with Cruikshank's narrowing of the right of assembly ${ }^{405}$ - merely to guard against state interference with the writ as handled in federal court, such protection would be redundant given the Supremacy Clause. ${ }^{406}$ Professor Crosskey suggested that the proper incorporationist reading is that "the guaranty against suspension [of the writ is] now operative against the states in their own courts." 407 The constitutional dimension of habeas corpus is a complex and fascinating issue, but any further exploration of it would outrun the scope of this article. 408

Sooner or later, the present or future Supreme Court will be faced with one or more of these leftover issues. When that happens, the "uneasy," "awkward," and "textually untenable theory of "selective incorporation" will "undergo

401367 U.S. $488(1961)$.
402 Id. at $489 \&$ n.1, 496.
403 Id. at 489 n.1.
404 Slaughter-House, 83 U.S. (16 Wall.) at 79; see also Wildenthal, Lost Compromise, supra note 9, at Part II.C.

405 See Cruikshank, 92 U.S. at 551-53; Wildenthal, Lost Compromise, supra note 9, at Part III.C.

406 See U.S. CONST. art. VI, cl. 2; 2 CROSSKEY, POLmCS, supra note 13, at 1129; Amar, supra note 12 , at 1258 .

4072 CROSSKEY, POLITICS, supra note 13, at 1129.

408 Cf., e.g., Eric M. Freedman, Milestones in Habeas Corpus, Part I-Just Because John Marshall Said It, Doesn't Make It So: Ex Parte Bollman and the Mlusory Prohibition on the Federal Writ of Habeas Corpus for State Prisoners in the Judiciary Act of 1789, 51 ALA. L. REV. 531 (2000); Eric M. Freedman, Milestones in Habeas Corpus, Part II-Leo Frank Lives: Untangling the Historical Roots of Meaningful Federal Habeas Corpus Review of State Convictions, 51 ALA. L. REV. 1467 (2000); Eric M. Freedman, Milestones in Habeas Corpus, Part III-Brown v. Allen: The Habeas Corpus Revolution That Wasn't, 51 ALA. L. REv. 1541 (2000); Jordan Steiker, Incorporating the Suspension Clause: Is There a Constitutional Right to Federal Habeas Corpus For State Prisoners?, 92 MiCH. L. REV. 862 (1994). 
uncomfortable scrutiny." 409 Will the Court pick up where it left off in Benton more than thirty years ago? Will it go back to first principles and resurrect the "lost compromise" of total and textual incorporation implied by Slaughter-House and reflected in the consensus on that issue among Republicans and Democrats in the Congress of the early $1870 \mathrm{~s}$ ? ${ }^{410}$

That this day of reckoning may not be far off was dramatically signalled in 1999 when the Court decided Saenz v. Roe. ${ }^{411}$ Although Saenz did not directly implicate the incorporation issue, ${ }^{412}$ it is the Court's only extant decision to strike down a state law - and by a lopsided seven-to-two vote - under the Fourteenth Amendment Privileges and Immunities Clause. ${ }^{413}$ As if that alone were not startling enough, the two dissenters-Justice Clarence Thomas and Chief Justice William $H$. Rehnquist-suggested what may amount to an even more activist approach. They bluntly criticized Slaughter-House for (as the conventional view would have it) "all but read[ing] the ... Clause out of the Constitution."414 Declaring that "the demise of the ... Clause has contributed in no small part to the current disarray of our Fourteenth Amendment jurisprudence," they announced themselves "open to reevaluating its meaning in an appropriate case." 115 And, they stated: "Before invoking the Clause, ... we should endeavor to understand what the framers of the Fourteenth Amendment thought that it meant. We should also consider whether the Clause should displace, rather than augment, portions of our equal protection and substantive due process jurisprudence." 416

This article has sought to set the record straight regarding the Court's callous and ill-reasoned disincorporation of almost all of the Bill of Rights between 1880 and 1908. It has, at long last, analyzed the opinions, briefs, and arguments in the Court in a fair and comprehensive light, sympathetic to the incorporationist goals of those who proposed the Fourteenth Amendment, and-as recounted in this author's previous article - the incorporationist consensus briefly achieved but then lost in the $1870 \mathrm{~s}^{417}$ That history poses a warning to the present and future Courts, and remains an institutional debt. The twentieth-century Court-primarily the

409 Wildenthal, Lost Compromise, supra note 9, at 1055-56.

410 See id. at Parts II-III.A.1 and IV.

411526 U.S. 489 (1999).

412 It upheld the principle of free interstate migration and equal treatment by the states of newly migrated state citizens. See id. at 503,510-11 (striking down Califomia law denying equal welfare benefits to recent migrants).

413 See Wildenthal, Lost Compromise, supra note 9, at Parts I.A and II.A. See generally Tribe, Saenz, supra note 13.

414 Saenz, 526 U.S. at 521 (Thomas, J., joined by Rehnquist, C.J., dissenting).

$415 \mathrm{Id}$. at 528 (Thomas, J., joined by Rehnquist, C.J., dissenting).

416 Id.

417 See generally Wildenthal, Lost Compromise, supra note 9. 
Warren Court during the eight short years from 1961 to 1969-paid off much of that historical debt by restoring most Bill of Rights guarantees to their rightful protected place in the Fourteenth Amendment. The present and future Courts should be mindful of that history, and that debt, in construing the Constitution for the twenty-first century and beyond. 